PNL-4653 I-

NUREG/CR-3194 PNL-4653

\title{
Improved Cost-Benefit Techniques in the U.S. Nuclear Regulatory Commission
}

Prepared by F. J. Cronin, R. J. Nesse, M. Vaeth, A. R. Wusterbarth, J. W. Currie

Pacific Northwest Laboratory Operated by

Battelle Memorial Institute

Prepared for U.S. Nuclear Regulatory Commission 


\section{NOTICE}

This report was prepared as an account of work sponsored by an agency of the United States Government. Neither the United States Government nor any agency thereof, or any of their employees, makes any warranty, expressed or implied, or assumes any legal liability of responsibility for any third party's use, or the results of such use, of any information, apparatus, product or process disclosed in this report, or represents that its use by such third party would not infringe privately owned rights.

\section{Availability of Reference Materials Cited in NRC Publications}

Most documents cited in NRC publications will be available from one of the following sources:

1. The NRC Public Document Room, 1717 H Street, N.W. Washington, DC 20555

2. The NRC/GPO Sales Program, U.S. Nuclear Regulatory Commission, Washington, DC 20555

3. The National Technical Information Service, Springfield, VA 22161

Although the listing that follows represents the majority of documents cited in NRC publications, it is not intended to be exhaustive.

Referenced documents available for inspection and copying for a fee from the NRC Public Document Room include NRC correspondence and ir.ternal NRC memoranda; NRC Office of Inspection and Enforcement bulletins, circulars, information notices, inspection and investigation notices; Licensee Event Reports; vendor reports and correspondence; Commission papers; and applicant and licensee documents and correspondence.

The following documents in the NUREG series are available for purchase from the NRC/GPO Sales Program: formal NRC staff and contractor reports, NRC-sponsored conference proceedings, and NRC booklets and brochures. Also available are Regulatory Guides, NRC regulations in the Code of Federal Regulations, and Nuclear Regulatory Commission /ssuances.

Documents available from the National Technical Information Service include NUREG series reports and technical reports prepared by other federal agencies and reports prepared by the Atomic Energy Commission, forerunner agency to the Nuclear Regulatory Commission.

Documents available from public and special technical libraries include all open literature items, such as books, journal and periodical articles, and transactions. Federal Register notices, federal and state legislation, and congressional reports can usually be obtained from these libraries.

Documents such as theses, dissertations, foreign reports and transiations, and non-NRC conference proceedings are available for purchase from the organization sponsoring the publication cited.

Single copies of NRC draft reports are available free upon written request to the Division of Technical Information and Document Control, U.S. Nuclear Regulatory Commission, Washington, DC 20555 .

Copies of industry codes and standards used in a substantive manner in the NRC regulatory process are maintained at the NRC Library, 7920 Norfolk Avenue, Bethesda, Maryland, and are available there for reference use by the public. Codes and standards are usually copyrighted and may be purchased from the originating organization or, if they are American National Standards, from the American National Standards Institute, 1430 Broadway, New York, NY 10018. 
NUREG/CR-3194

PNL-4653

RE

\section{Improved Cost-Benefit Techniques in the U.S. Nuclear Regulatory Commission}

Manuscript Completed: January 1983

Date Published: June 1983

Prepared by

F. J. Cronin, R. J. Nesse, M. Vaeth,

A. R. Wusterbarth, J. W. Currie

Pacific Northwest Laboratory

P.O. Box 999

Richland, WA 99352

\section{Prepared for}

Division of Health, Siting and Waste Management

Office of Nuclear Regulatory Research

U.S. Nuclear Regulatory Commission

Washington, D.C. 20555

NRC FIN B2381 



\begin{abstract}
The major objective of this report is to help the U.S. Nuclear Regulatory Commission (NRC) in its regulatory mission, particularly with respect to improving the use of cost-benefit analysis and the economic evaluation of resources within the NRC. The objectives of this effort are: (1) to identify current and future NRC requirements (e.g., licensing) for valuing nonmarket goods; (2) to identify, highlight, and present the relevant efforts of selected federal agencies, some with over two decades of experience in valuing nonmarket goods, in this area; and (3) to review methods for valuing nonmarket impacts and to provide estimates of their magnitudes.

Recently proposed legislation may result in a requirement for not only more sophisticated valuation analyses, but more extensive applications of these techniques to issues of concern to the NRC. This paper is intended to provide the NRC with information to more efficiently meet such requirements.
\end{abstract}





\section{CONTENTS}

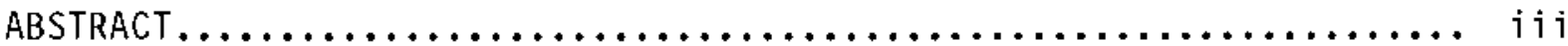

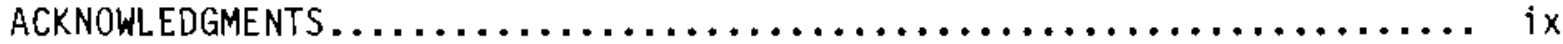

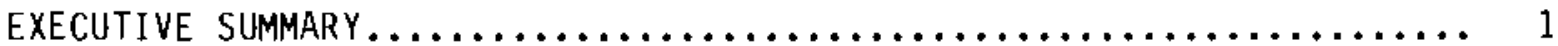

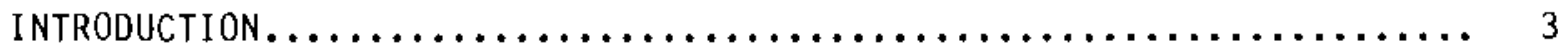

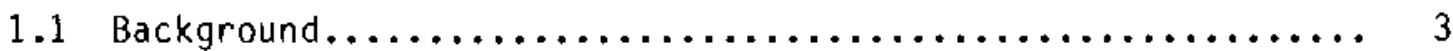

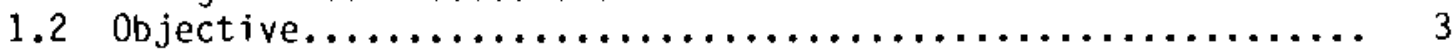

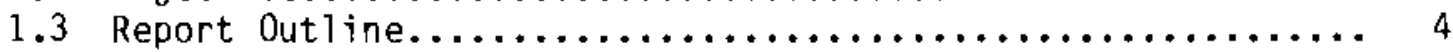

2. COST-BENEFIT ANALYSIS IN THE NRC $\ldots \ldots \ldots \ldots \ldots \ldots \ldots \ldots \ldots \ldots \ldots \ldots \ldots \ldots \ldots \ldots \ldots$

2.1 National Environmental Policy Act................... 6

2.2 NRC Implementation of Environmental Legislation........... 7

2.3 NRC Analysis of Safety Issues....................... 9

2.4 Implications of Pending Legislation.................. 11

2.4.1 Regulatory Reform Legislation................. 11

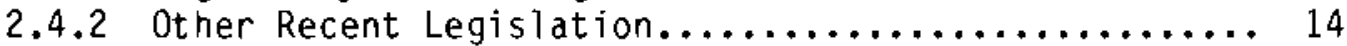

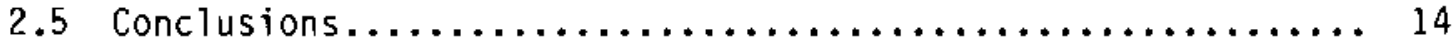

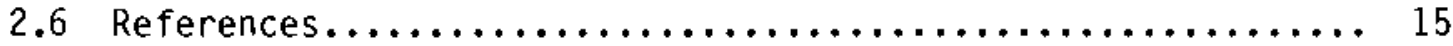

3. COST-BENEFIT ANALYSIS IN OTHER FEDERAL AGENCIES $\ldots \ldots \ldots \ldots \ldots \ldots \ldots$

3.1 The Environmental Protection Agency................ 17

3.1.2 Nonmarket Impact Assessment Process............... 19

3.1.2.1 Valuation of Human Health Benefits........ 21

3.1.2.2 Valuation of Nonhealth Benefits.......... 21

3.1.3 Specific Nonmarket Impact Analysis.............. 22

3.2 The U.S. Fish and Wildlife Service................ 24

3.2 .1 Relevance to the NRC..................... 27

3.2.2 Nonmarket Impact Assessment Process............... 28

3.2.3 Specific Nonmarket Impact Analyses............... 30 
3.3 The Bonneville Power Administration................. 32

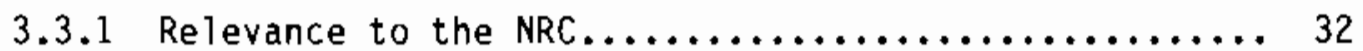

3.3 .2 Nonmarket Impact Assessment Process............... 33

3.3 .2 .1 Interim Procedures................. 34

3.3.2.2 Proposed Procedures.................. 35

3.3.3 Specific Nonmarket Impact Analyses.............. 39

3.4 The Water Resources Council..................... 39

3.4.1 Relevance to the NRC....................... 41

3.4.2 Nonmarket Impact Assessment Process............... 42

3.4.3 Specific Nonmarket Impact Analyses.............. 46

3.5 References............................. 47

4. A REVIEW OF METHOOS AND ESTIMATES FOR VALUING

NONMARKET GOODS................................. 49

4.1 Measuring the Value of Environmental Changes............ 49

4.1 .1 Measuring Values Directly................. 50

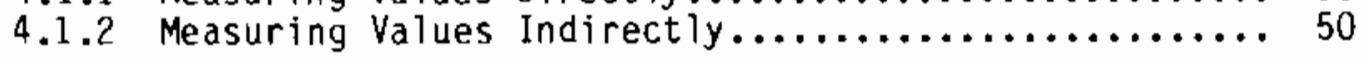

4.1.2.1 Nonmarket Goods as Household Inputs....... 50

4.1.2.2 Nonmarket Goods Valued Through

Contingent Methods.................. 53

4.2 Some Suggested Criteria for Evaluating

Candidate Methodologies......................... 59

4.3 References............................... 68

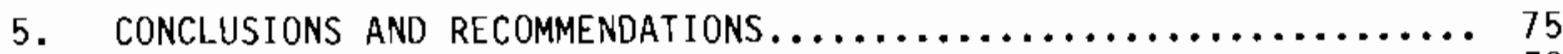

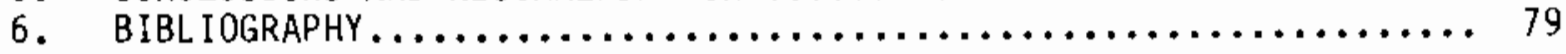

APPENDIX A - SENATE AND HOUSE VERSIONS OF THE REGULATORY

REFORM BILL............................. 91 
APPENDIX B - SOURCES OF SURVEY DATA.................... 93

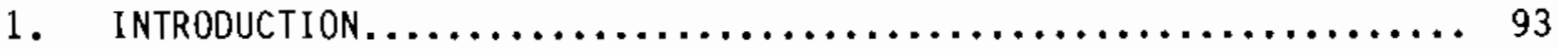

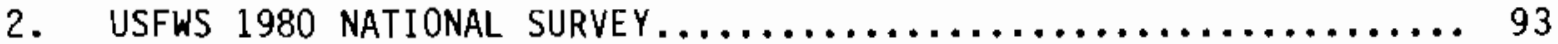

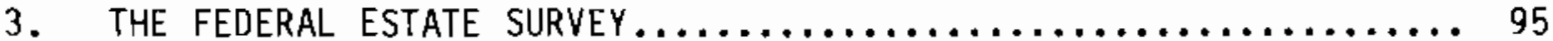

4. RECREATION RESOURCE MANAGEMENT SYSTEM................... 95

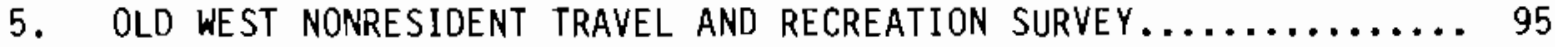

6. RECREATION DEMAND SURVEY AND FORECASTS $\ldots \ldots \ldots \ldots \ldots \ldots \ldots \ldots \ldots \ldots \ldots . . \ldots 6$

7. THE $1982-1983$ NATIONWIDE RECREATION SURVEY................ 96

APPENDIX C - ANALYSIS AND RECOMMENDATIONS REGARDING THE TREATMENT DF "INDIRECT BENEFITS" IN THE DRAFT ENVIRONMENTAL STATEMENT RELATED TO THE DPERATION OF PERRY NUCLEAR POWER PLANTS, UNITS 1 AND $2 \ldots \ldots \ldots \ldots \ldots \ldots \ldots \ldots \ldots . \ldots . \ldots 9$

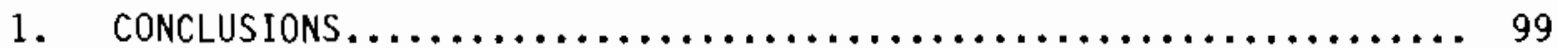

2. TAXES AND TRANSFER PAYMENTS $\ldots \ldots \ldots \ldots \ldots \ldots \ldots \ldots \ldots \ldots \ldots \ldots \ldots \ldots \ldots \ldots$

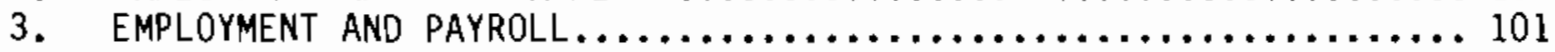

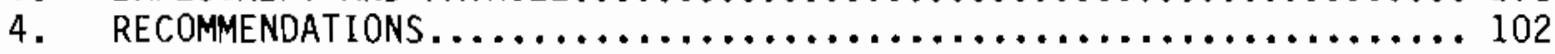

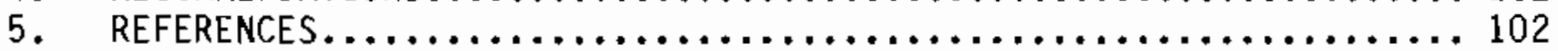





\section{ACKNOWLEDGMENTS}

The authors acknowledge several individuals for their assistance during this project. Or. J. Clark Prichard, U.S. Nuclear Regulatory Cominission, provided valuable insights and suggestions. Mr. Donald Cleary and Mr. Brian Richter, U.S. Nuclear Regulatory Commission, also made valuable suggestions.

Appreciation is due to Marlene Hale who provided final word processing and manuscript preparation. 



\section{IMPROVED COST-BENEFIT TECHNIQUES IN \\ THE NUCLEAR REGULATORY COMMISSION}

\section{EXECUTIVE SUMMARY}

This report describes research performed by Pacific Northwest Laboratory (PNL) for the U.S. Nuclear Regulatory Commission (NRC). The information presented in this report is intended to help the NRC in its regulatory mission, particularly with respect to improving its use of cost-benefit analysis and the economic evaluation of resources. In addition, information useful for developing and applying cost-benefit analysis is provided.

A major objective of this research is to provide assistance to the NRC for improving the technical basis for the environmental review of nuclear facilities. Analytical requirements for evaluating expected economic benefits from a nuclear facility are difficult because various nonmarket impacts (e.g., environmental impacts) are not easily quantified in commensurable units. Consequently, overall cost-benefit estimates of a nuclear facility have been difficult to identify. In order to help resolve this problem, PNL has reviewed the approaches of the NRC and other federal agencies for performing cost-benefit analyses. Further, PNL has extensively reviewed the literature for methods and estimates of valuing nonmarket goods.

The NRC faces many of the same decisions as other federal agencies. For example, both the NRC and the Army Corps of Engineers must decide whether to allow large construction projects which may cause environmental damages. The Environmental Protection Agency and the NRC must of ten decide whether to regulate industry actions which may be damaging to the public health and safety. Cost-benefit analysis is becoming increasingly used by these other agencies as an aid in decision-making and could be helpful in the NRC. This report discusses the frameworks within which the NRC and several federal agencies conduct cost-benefit analysis. The report also discusses recently proposed regulatory reform legislation since this legislation may result in greater use of cost-benefit analysis in the NRC's environmental and safety decision-making.

Determining the values associated with environmental changes has become more important as more extensive regulations by government agencies have imposed increased costs on all sections of the econony. The question of whether the benefits of regulating impacts on nonmarket goods exceed costs arises frequently. In response, state and federal laws and regulations are requiring agencies to consider the environmental costs and impacts of their actions. In conjunction with the importance of environmental and economic considerations, methods which estimate the economic damages associated with environmental impacts become more important. In this report, PNL discusses and critiques eight methods capable of valuing (in monetary units) physical and biological damages. In effect, the methodologies enable estimates of costs and benefits to be made in commensurable units. 
In light of recently proposed legislation and the increasing emphasis on valuing nonmarket impacts, the NRC may be required to upgrade analytical techniques for performing regulatory analysis. This research paper provides the NRC with a review of current topics of concern and provides the NRC with information to familiarize, develop, and test techniques currently employed by researchers in this area. 


\section{INTRODUCTION}

The analysis described herein was performed by the Pacific Northwest Laboratory (PNL) for the Office of Nuclear Regulatory Research, U.S. Nuclear Regulatory Commission (NRC). The major objective of this report is to improve the economic valuation of resources and the implementation of cost-benefit analysis in the NRC. The objectives of this effort are: (1) to identify current and future NRC requirements (e.g., licensing) for valuing nonmarket goods; * (2) to identify, highlight, and present the relevant efforts of selected federal agencies, some with over two decades of experience in valuing nonmarket goods, in this area; and (3) to review methods for valuing nonmarket impacts and to provide estimates of their magnitudes.

Recent legislation, such as the Senate version of the Regulatory Reform Bill may result in a requirement for not only more sophisticated valuation analyses but more extensive applications of these techniques to issues of concern to the NRC (see Appendix A). This paper is intended to provide the NRC with information to more efficiently deal with such requirements.

\subsection{Background}

The analytical efforts of the NRC are affected by legislation and judicial rulings. The National Environmental Policy Act (NEPA) of 1969 established a national policy for the environment and required that federal agencies consider the environmental consequences of their actions. This act required that the NRC evaluate and compare the expected benefits and environmental costs resulting from such actions as granting reactor construction permits or operating licenses.

As an independent agency, the NRC is not subject to executive legislation. Other federal agencies, however, have had to comply with Executive Orders 12044 and 12291 which require thorough economic analyses for evaluating federal policies. In compliance with the recently proposed Regulatory Reform Bill, the NRC would have to implement provisions similar to Executive Order 12291. As a result, the NRC will be required to employ more rigorous costbenefit methods.

\subsection{Objective}

The licensing procedures for nuclear facilities call for consideration of a wide variety of potential nonmarket impacts (e.g., environmental impacts). Furthermore, the procedures require that impacts be placed in a cost-benefit framework, so that impacts can be evaluated and weighed against the overall

\footnotetext{
* Nonmarket goods are goods that are not transacted in markets. When the outputs of particular projects or programs (e.g., health and safety factors) are not sold in markets, the problem of valuation is difficult and it often becomes necessary to impute values to such nonmarket goods.
} 
economic benefits expected from the operation of the facility. To date, the latter requirement has been difficult to implement because the various types of nonmarket impacts are not easily quantified in commensurable units. As a result, overall cost-benefit estimates of a nuclear facility have been difficult to identify. Moreover, alternative site review under NEPA has been hampered by the lack of a way for evaluating nonmarket impacts at one site against those at other sites. This has led to uncertainties in the licensing process which contribute significantly to delays in that process.

This paper reviews the methods employed by federal agencies that have used cost-benefit analysis extensively. Their experience can help the NRC improve its cost-benefit analysis. A review of methods and estimates for valuing nonmarket goods from the economic literature is also provided. It is not expected that all nonmarket impacts will lend themselves to these approaches, but in many cases the quantitative evaluation of nonmarket impacts can be made. The successful development and application of methods to do this would substantially improve the technical basis for the environmental review of nuclear facilities.

\subsection{Report Outline}

Chapter 2 provides background information about cost-benefit analyses in the NRC. Because several federal agencies have been employing advanced research methods in their cost-benefit analyses, a survey of these agencies is provided in Chapter 3 of this report. Methodological issues of valuing nonmarket impacts are discussed in Chapter 4 . Conclusions and recommendations are offered in Chapter 5. Finally, Appendixes A and B provide supporting information about pending legislation and new survey data, respectively. Appendix $C$ addresses the question of including certain indirect benefits in the recent Draft Environmental Statement published by the NRC. 


\section{COST-BENEFIT ANALYSIS IN THE NRC}

The phrase "cost-benefit analysis" is often used by analysts to refer to a general, loosely defined method of assessing or evaluating actions. Broadly, cost-benefit analysis argues projects should be undertaken only if societal benefits outweigh societal costs (see, for instance, Ref. 1 and Ref. 2). Few would argue with basing decisions on such a criterion. For this report, we define cost-benefit analysis as an estimation of benefits and costs associated with alternative ways of achieving public goals. Ideally, all costs and benefits are expressed in terms of dollars. Our definition corresponds closely to cost-benefit analysis based on economic theory. When necessary, we refer to the cost-benefit analysis based on economic theory as "formal" cost-benefit analysis to distinguish it from the generic techniques of assessing public projects.

Many noneconomists misunderstand the rationale for using dollars to measure the costs and benefits of an action. Economists view market prices as reflecting the value society places on a comnodity. Costs, expressed in dollars, represent the value society places on the resources used in the project (including undesirable results); benefits represent the value society places on the positive results of the project (see Ref. 1, pp. 43-47 and Ref. 3). However, in many cases market prices either do not exist or do not reflect society's values. For example, a construction project negatively affects the visual aesthetics of the area. This represents a cost of the project. However, such costs are not paid by construction developers. Failure to consider the impacts on visual aesthetics may lead to proceeding with projects whose societal benefits do not outweigh societal costs.

Economists have developed techniques to simulate markets in order to estimate values of impacts, such as visual impacts, which do not have readily available prices. This allows explicit consideration of these impacts in an evaluation of the proposed action. Other chapters of this report describe these simulation and valuation techniques and their applications.

Cost-benefit analysis and the valuation techniques have been widely used to evaluate proposed public actions. Applications include evaluating such decisions as whether a dam should be constructed by estimating the value of fish and wildlife affected by the dam's construction: whether public expenditures on disease eradication should be undertaken and whether public construction projects such as a new tunnel should be built (Ref. 3 ).

The NRC faces many of the same decisions as other federal agencies. For example, both the NRC and the Army Corps of Engineers must decide whether to allow large construction projects which may cause environmental damages. The Environmental Protection Agency (EPA) and the NRC must often decide whether to regulate industry actions which may be damaging to the public nealth and 
safety. Cost-benefit analysis is increasingly being used by these other agencies as an aid in decision-making and could be helpful in the NRC. This chapter discusses the framework within which the NRC conducts cost-benefit analysis and other closely related techniques. Also, the chapter discusses recently proposed regulatory reform legislation since this legislation may result in greater use of cost-benefit analysis in NRC's environmental and safety decision-making.

\subsection{National Environmental Policy Act}

The enactment of the National Environmental Policy Act (NEPA) on January 1, 1970 , established a national policy for the environment and directed federal agencies to consider the environmental consequences of their actions. NEPA requires that agencies prepare an environmental impact statement (EIS) to identify the consequences of their actions and compare the consequences with those of alternatives. NRC actions which receive some level of review under NEPA include: (1) reactor construction permit applications; (2) reactor operating license applications; (3) program studies; (4) promulgation of regulations; and (5) changes to operating licenses including decommissioning (10 CFR 51:5).

The procedural provisions for implementing NEPA (940 CFR 1500-1508) do contain some broad guidelines for comparing the desirability of the project and its alternatives. For example, the provisions require that the EIS contain discussions of direct and indirect environmental effects and their significance. Although it is not required under NEPA, one way of determining the significance of environmental effects is to measure the value society places on the forgone resources, that is, to perform a cost-benefit analysis. However, NEPA does not require a formal cost-benefit analysis. The regulations for implementing NEPA state: "For purposes of complying with the Act, the weighing of the merits and drawbacks need not be displayed in a monetary cost-benefit analysis..." (40 CFR 1502.22)

The use of cost-benefit analysis in the NEPA process was considered by the courts in the Calvert Cliffs Coordinating Committee vs AEC decision. In this decision, the court held that NEPA requires a case-by-case balancing of the economic, technical, and environmental factors. The court said, "In each individual case, the particular economic and technical benefits of planned action must be weighed against the environmental costs; alternatives must be considered which affect the balance of values." (2 ERC 1779, D.C. Cir. 1971). Section 2.2 of this chapter describes how the NRC has implemented NEPA and balances benefits and costs.

Responsibility for overseeing agency implementation of NEPA rests primarily with the Council on Environmental Quality (CEQ), although other agencies such as the Water Resources Council do have specific responsibilities (Executive Order No. 11991, 3 CFR 123). While NEPA does not require a cost-benefit 
analysis, CEQ has encouraged tools and methods which would allow estimating the dollar values of environmental impacts (Ref. 4).

The Water Resources Council (WRC), which is responsible for the evaluation of national water and land-related resource projects, has explicitly incorporated the provisions of NEPA into a formal cost-benefit framework prescribed in recently published guidelines for evaluating water and land-related resource projects. The WRC and its evaluation procedures are discussed in Chapter 3.

NRC's responsibilities under NEPA are also affected by the Federal Water Pollution Control Act (FWPCA) which gives the Environmental Protection Agency (EPA) authority over pollutants discharged into U.S. waters. Since information and licenses required under FWPCA may overlap with NEPA requirements, the NRC and EPA have reached an understanding of their respective roles (Second Memorandum of Understanding and Policy Statement Regarding Implementation of Certain NRC and EPA Responsibilities, $40 \mathrm{FR} \mathrm{60115).} \mathrm{For} \mathrm{example,} \mathrm{EPA} \mathrm{pre-}$ sently has jurisdiction over the choice of cooling alternatives for a nuclear power plant. Thus, the EPA is responsible for evaluating the environmental impacts of decisions under its jurisdiction.*

\subsection{NRC Implementation of Environmental Legislation}

Responsibility for NEPA review and compliance is allocated to the individual NRC office responsible for the program. For example, the Assistant Oirector for Environmental Technology of Nuclear Reactor Regulation (NRR) is responsible for environmental and safety reviews and issues related to reactor licenses. The Office of Nuclear Material Safety and Safeguards is generally responsible for the environmental and safety reviews of the portions of the nuclear fuel cycle other than the construction and operation of reactors (Ref. 5). Other offices also have responsibilities.

The NRC's statutory authority, the Atomic Energy Act of 1954 and the Energy Reorganization Act of 1974 , do not require that the NRC conduct cost-benefit analysis. However, the 1954 Atomic Energy Act and subsequent NEPA decisions created the implied authority to use a balancing approach to the achievement of environmental and safety goals (Ref. 6). The cost-benefit balance is a part of each Environmental Impact Statement (EIS) prepared for plant construction permits and operating 1icenses.

*Staff of the NRC's Environmental Engineering Branch contend that in spite of the Memorandum of Understanding between the NRC and EPA, the NRC has final authority over plant construction and operation. This is achieved through its reviews for construction permits and operating licenses. The NRC has the final responsibility for weighing the costs and benefits of the plant construction and operation. 
NRC procedures and requirements for preparing an EIS and other documents related to NEPA are contained in the Code of Federal Regulations

(10 CFR 51). This document contains information on how the applicant for the construction permit or operating license should prepare its required Environmental Report and how the NRC will prepare an EIS. The section relating to cost-benefit analysis (10 CFR 51.23) states:

The draft environmental impact statement will include a preliminary cost-benefit analysis which considers and balances the environmental and other effects of the facility and the alternatives available for reducing or avoiding adverse environmental and other effects, as well as the environmental, economic, technical, and other benefits of the facility.

Several internal documents are used by NRC personnel to ensure that material is available to perform each EIS in a consistent manner. One is an NRC Regulatory Guide, Preparation of Environmental Reports for Nuclear Power Stations) (Ref. 7) which provides guidance to applicants on submitting Environmental Reports to the NRC. The other document is the Environmental Standard Review Plans (ESRP) (Ref. 8) whose purpose is to provide instructions to staff on conducting environmental reviews.

The NRC instruction documents (Ref. 7 and Ref. 8) do require a lengthy treatment of environmental impacts but the impacts can be measured in terms of the magnitude of environmental consequences and need not be monetized. For example, fish may be harmed as they are trapped by the cooling water intake structure. The environmental impact is measured as the percent of population or actual numbers destroyed each year. The Regulatory Guide and the ESRPs do not require, nor does NRC attempt, an estimate of the value of this lost resource. For example, Reference 7, page 11, states:

Although the cost-benefit analysis approach discussed in this guide is conceptually similar to the cost-benefit approach classically employed in a purely economic context, the method recommended differs from it procedurally. This is because the benefits and costs to be evaluated will not all be monetized by the applicants. The incommensurable nature of the benefits and costs make it virtually impossible to provide a concise assessment of costs versus benefits in classical quantitative terms. Even though a simple numerical weighing of benefits against costs is clearly not feasible here, the applicant can evaluate the factors on a judgmental basis that is consistent with the underlying concept of cost-benefit analysis.*

*The Regulatory Guide (Ref. 7) was published in 1976. It states "a simple numerical weighing of benefits against costs is clearly not feasible here." While techniques were available prior to 1976, recent advances in valuation techniques and methods make valuing these impacts a possibility. 
Methods to estimate the value of lost fish have been greatly improved and validated during the past few years. For example, the U.S. Fish and Wildlife Service has used techniques (contingent market surveys) to estimate monetary values to the fish lost due to hydropower facilities in the Pacific Northwest (see Ref. 9).

A likely place in NRC's EIS to present a formal cost-benefit analysis would be in Chapter 6, Evaluation of the Proposed Action. This chapter includes a "Benefit-Cost Summary" which is a compilation of environmental impacts, project benefits, and information on socioeconomic effects along with a staff assessment of the magnitude of the benefit or cost.* The staff assessment is a judgmental decision because none of the effects are in commensurable units. The staff decides whether the benefits or costs are large, moderate, smal1, or none. For example, Chapter 6 of the EIS includes estimates of electrical energy produced in $\mathrm{kWh} /$ year, reduced generating costs in dollars/year and operating costs in mills per $k$ wh for fuel and operation and maintenance costs and in total dollars for decommissioning costs. The staff includes its judgment in its recommendation whether the plant should be allowed to be constructed or operated.

A previous review performed for the Administrative Conference of the United States on the use of a cost-benefit analysis in federal agencies concluded:

NRC use of cost-benefit to establish generically-applicable standards and other regulations, and to make licensing determinations of specific applications, represent useful approaches to rational decision-making. However, considerable methodological, societal and legal issues are raised, which the agency is unable to fully resolve on its own, despite its considerable efforts. Judicial review of NRC actions has not resolved these issues. (Ref. 6, P. A-3). ${ }^{\star \star}$

We describe how other agencies are approaching their cost-benefit analyses elsewhere in this report. Their experience can help the NRC approach the task of improving its cost-benefit analysis.

\subsection{NRC Analysis of Safety Is sues}

Safety and risk decisions may also benefit from an analysis of the proposed action's costs and benefits. Because the resources used to increase plant safety are not available for other uses (including reducing other risks), society would probably not wish to bear the costs of reducing the risks of

*Appendix $C$ examines the treatment of "Indirect Benefits" in the "BenefitCost Summary."

**Essentially the same conclusion is reached by Paul Joskow (Ref. 10) and Matifyahu Marcus (Ref. 11), who contend among other concerns, the NRC improperly treats certain impacts of plant construction. 
operating a nuclear power station below some level. At some point, the gains of further safety improvements are not worth the additional cost, and resources could be better spent reducing other societal risks than further safety improvements at a light water reactor (LWR). The NRC has recognized that tradeoffs are required in implementing safety goals.* For example, the Commission's Proposed Policy Statement on Safety Goals for Nuciear Power Plants (Ref. 13) proposes a guideline of $\$ 1,000$ per man-rem averted as a provisional guide for reaching decisions which may require evaluation of the costs and benefits of additional safety features. For example, a safety retrofit which costs more than $\$ 1,000$ per man-rem averted would not be required by the $\mathrm{NRC}$.

The Commission's guidelines should help encourage analysis comparing incremental costs and benefits of safety issues. The Commission states in Reference 13, p. 11:

This guideline is intended to encourage the efficient allocation of resources in a safety-related activity by providing that the

\footnotetext{
*The Senate version of the Regulatory Reform Bill, S. 1080, will have major, but unknown, consequences on the Administration's efforts to reduce the burden of regulations on industry. As noted by a recent government report (Ref. 12, p. 40),

S. 1080 would not affect the Administration's deregulatory program insofar as that program was effected through changes in budgets and enforcement policy. The Administration's program also consists of broad policy priorities set by the President and the Task Force on Regulatory Relief on proposed regulatory legislation, regulatory relief for different industries, etc. S. 1080 could interfere with efforts to provide relief for particular industries if that relief were not consistent with the principles of E.0. 12291. For example, the U.S. Court of Appeals for the District of Columbia Circuit recently held that the National Highway Traffic Safety Administration's decision to provide relief for the automobile industry by rescinding the passive restraints rule 1) was not based on adequate information; 2) was likely, based on the information available, to result in potential costs exceeding its potential benefits; 3) did not maximize the net benefits to society; and 4) did not seriously consider, much less choose, the alternative with the least net cost to society. While the court decision does not explicitly assess the compliance of the agency with the principles of Executive Order 12291, its findings suggest that the agency violated four of the principles of the Executive Order in an effort to provide relief to a major industry.
} 
expected reduction in public risk that would be achieved should be commensurate with the costs of the proposed safety improvements.

The benefits of an incremental reduction of risk below the numerical guidelines for societal mortality rates should be compared with the associated costs, including all reasonably quantifiable costs.

\subsection{Implications of Pending Legislation}

Recently proposed legislation may result in the NRC adopting more rigorous cost-benefit methods. Most are not yet directly applicable to NRC's analysis under NEPA, but they do show congressional intent in this area.* However, one bill, the Regulatory Reform Bill (H.R. 746 and S. 1080) which has been passed by the Senate and is being considered by the House, would require NRC to perform a formal analysis before implementing major regulatory requirements. Most agencies are taking this analytical requirement to be formal, costbenefit analysis. The following section describes several of these congressional actions and their implications for the NRC.

\subsubsection{Regulatory Reform Legislation}

The issuance of Executive Order 12044 in 1978 by President Carter set out a series of reforms of the federal regulatory process. Among other things, the Executive 0rder required each executive agency to prepare a regulatory analysis for regulations which would have a major impact on the U.S. economy. Executive agencies prepared procedures for implementing Executive Order 12044 and began preparing regulatory analyses. Although the NRC, as an independent agency, does not need to comply with the Executive Order, it recently put guidelines for cost-benefit analysis in place (see Ref. 15).

While agencies differed in their treatment of the regulatory analysis, the executive intent is apparent from $0 \mathrm{MB}^{\prime}$ 's review of agencies' responses to Executive 0 rder 12044. OMB stated that as a result of the regulatory analysis, agency personnel "have the benefit of a discussion of alternative choices, quantified to the greatest extent possible, before the agency proposes the new regulation." (Ref. 16). Most agencies treated the analysis requirement as something close to a cost-benefit analysis whose purpose was to identify alternative approaches to accomplishing the regulatory goals, evaluate each alternative and justify whatever alternative was selected.

Among other changes, President Reagan's regulatory reform initiative, Executive Order 12291 (Ref. 17), strengthened the analytical provisions of

*For example, the Pacific Northwest Electric Power Planning and Conservition Act (Ref. 14) requires formal cost-benefit analysis in the choice of enery. generation and conservation alternatives. 
Carter's Executive Order.* For example, Executive Order 12291 required that the chosen alternative must be the one which involved the least net cost to society and that "Agencies shall set regulatory priorities with the aim of maximizing the aggregate net benefits to society...." The office of Management and Budget (OMB) was responsible for developing procedures for analyzing regulatory impacts (see Ref. 18). The OMB guidance listed 5 elements which should be contained in a Regulatory Impact Analysis (RIA). These elements are:

(1) statement of need for and consequences of the proposal;

(2) examination of alternative approaches;

(3) analysis of benefits and costs;

(4) rationale for choosing the proposed regulatory action;

(5) statutory authority.

OMB's discussion of element 3, analysis of benefits and costs, in Reference 18 (p. 3) states that "benefits that can be estimated in monetary terms should be expressed in constant dollars," and "The analysis should include estimates of the present value of all the real incremental costs of the proposed regulatory change and its principal alternatives."

Other agencies are conducting cost-benefit analysis as though the RIA required a formal, economic based, cost-benefit analysis. For example, the Environmental Protection Agency in internal guidance on the RIA states the benefitcost analysis required for RIAs has as its cornerstone the principle of economic efficiency. According to this principle, projects should be undertaken

\footnotetext{
*A. Fraas ("Benefit-Cost Analysis for Environmental Regulations: An OMB Perspective." Paper presented at the Conference on the Implications of Executive Order 12291 for Environmental Policy, Chapel Hill, North Carolina, October 11-12, 1982) states on page 14 of his paper that Executive Order 12291 establishes "a set of 'technology-forcing' requirements. The Executive Order requires important institutional changes in the way information is developed and organized in addressing regulatory issues. In addition, satisfying these requirements poses some major analytical challenges. Some of these analytical problems include: developing the analysis in a timely fashion (often with limited funding), sorting out regulatory issues deserving review, and developing estimates with a level of precision that will inform the decision-making process." Fraas also states, "as a 'technology-forcing' requirement, the Executive Order requires the application of benefit/cost analysis to regulatory decision-making in areas where it has not been used before. The attempt to develop these analyses will raise important methodological issues that must be resolved before we can accept the indicated results with any confidence. As a result, Executive Order 12291 is only one of the initial steps in the long process of improving environmental regulation."
} 
only if benefits exceed costs. Determining this will require the quantification and valuation in dollar terms, insofar as possible, of the benefits and costs involved in an action's full range of effects -- e.g., from release of pollutants to their ultimate harmful effects on humans and the environment (see Ref 19).*

Since the NRC is an independent agency, it is not bound by the requirements of Executive Order 12291 which apply only to executive agencies. However, a bill has been passed by the Senate (see Appendix A) which would require all agencies, irscluding independent regulatory agencies, such as the NRC, to implement provisions similar to Executive Order 12291. The House is considering a similar bill, H.R. 746, the Regulatory Procedure Act of 1982 (Ref. 20). The major difference between the House and Senate versions is that in the Senate version the President or his designee (assumed to be OMB) will monitor and review the assessment and evaluations of all agencies including the independent agencies. In the House version, there would not be outside review of the procedures of the independent agencies; however, the NRC would still be required to perform "an analysis of the projected benefits and adverse economic and other effects of the proposed rule" (Ref. 20, p. 6). Passage of either version would have the effect of imposing stronger analytical requirements on the NRC.**

The Office of Risk Analysis, the Division of Regulatory Research has prepared a guidebook for NRC personnel to use in evaluating regulatory and safety requirements. This guidebook, presently in draft form, advocates a costbenefit type analysis before implementing a regulation and discusses various costs and benefits to be included. These costs and benefits are to be monetized to a much greater degree than required for the EIS.

The U.S. Regulatory Council (Ref. 21) recently undertook a survey of federal agency experiences as part of a broad effort to improve the quality and extent

*EPA's Economic Analysis Division (EAD) will be issuing guidelines for conducting RIAs in the Federal Register. These guidelines are based on rigorous welfare economics. In addition, all RIAs conducted by EPA program offices will be reviewed by EAD for compliance with the guidelines before the RIA is submitted to OMB.

* Moreover, S. 1080 would expand the coverage of regulatory analysis requirements. In particular, the "major rule" criterion in S. 1080 includes certain major deregulatory initiatives. The Senate Bill defines a rule as major if it is likely to result in:

1. "a \$ million annual effect on the economy in reasonably quantifiable direct and indirect costs; or

2. a substantial increase in costs or prices for wage earners, consumers, individual industries, non-profit organizations, Federal, State, and local governments, or geographic regions; or

3. significant adverse effects on competition, employment, investment, productivity, innovation, the environment, public health or safety or competition in domestic or export markets." 
of the analytical base for regulatory decision-making. A primary objective of the survey was to assist in identifying the means by which the Regulatory Council and OMB could help agencies improve regulatory analyses. Another emphasis was placed on collecting the views of experienced analysts about what steps agencies themselves might undertake to improve their regulatory analysis efforts. A third objective was to summarize the key elements of agencies' experience for consideration in developing new administrative steps and legislation defining agency analytical responsibilities.

\subsubsection{Other Recent Legislation}

The Pacific Northwest Electric Power Planning and Conservation Act (Regiona) Act) is a second example of federal executive and legislative movement to using formal, cost-benefit type analysis to reach decisions on environmental matters. The Regional Act and the Pacific Northwest Electric Power and Conservation Planning Council were set up to help develop a regional conservation and electric power plan. The Regional Act, described further in this report, requires that resources which are developed be cost-effective, where cost-effectiveness includes quantifiable environmental impacts of constructing and operating electrical generating facilities. The Planning Council expects to monetize many of the same impacts which are not monetized by the NRC.

\subsection{Conclusions}

The laws such as NEPA requiring the NRC to consider the environmental consequences of its actions do not require a formal cost-benefit analysis. Neither do NRC directives of policies which direct NRC staff on how to implement the environmental laws. Two points are worth mentioning:

(1) NRC has taken little initiative in attempting to implement costbenefit analysis. As a result, its methods are significantly less refined than those of other agencies.

(2) NRC has limited experience in rigorous cost-benefit analysis. Most cost-benefit work done within the NRC is performed by staff with no training in welfare economics or experience in formal cost-benefit analysis.

Recent congressional and executive initiatives may require the NRC to employ more sophisticated analytic and economic methods for estimating environmental and safety impacts. The following chapters of this report describe the considerable progress made by other agencies in valuing environmental impacts and the use of cost-benefit analysis in environmental decision-making. Most of this progress has occurred as a result of improvements in evaluation methods since the introduction of NEPA. 


\subsection{References}

1. P. G. Sassone and W. A. Shaffer, Cost-Benefit Analysis: A Handbook, p. 3, Academic Press, New York, 1978.

2. E. S. Quade, Analysis for Public Decisions, Pp. 20-21, Elsevies, New York, 1975.

3. E. J. Mishan, Cost-Benefit Analysis, PP. 24-25, Praeger Publishers, New York, 1976.

4. U.S. Council on Environmental Quality, Environmental Quality-1979, PP. 648-655, U.S. Government Printing office, 1979. Copies are available from the U.S. Government Printing Office, Washington, D.C.

5. Environmental Law Institute, NEPA in Action: Environmental offices in Nineteen Federal Agencies, P. 243. Prepared for the U.S. Council on Environmental Quality, Washington, D.C., 1981. Available for purchase from the U.S. Government Printing Office, Washington, D.C.

6. M. S. Baram, Regulation of Health Safety and Environmental Quality and the Use of Cost-Benefit Analysis, p. 57. Prepared for the Administrative Conference of the United States, Washington, D.C., 1978.

7. U.S. Nuclear Regulatory Commission, Preparation of Environmental Reports for Nuclear Power Stations, USNRC Report NUREG-0099, Regulatory Guide 4.2, Revision 2, 1976. Available for purchase from the National Technical Information Service, Springfield, Virginia 22161.

8. U.S. Nuclear Regulatory Commission, Environmental Standard Review Plans for the Environmental Review of Construction Permit Applications for Nuclear Power Plants, USNRC Report NUREG-0555, 1979. Available for purchase from the National Technical Information Service, Springfield, Virginia 22161.

9. Northwest Resource Information Center, Inc., "Cogeneration of Electrical Energy and Anadromous Salmon and Steelhead in the Upper Columbia River Basin: An Economic Perspective on the Question of Balance," Eagle, Idaho, June, 1982. Prepared for the U.S. Fish and Wildi ife Service, Washington, D.C.

10. P. L. Joskow, "Approving Nuclear Power Plants: Scientific DecisionMaking or Administrative Charade," The Bell Journal of Economics and Management Science, 320-331, (Spring, 1974). Available in public and technical libraries.

11. M. Marcus, "The Economic Benefits of Nuclear Power Plants," Public Utilities Fortnightly, 26-30, (June 20, 1974). Available in pubtic and technical libraries. 
12. U.S. General Accounting Office, Improved Quality, Adequate Resources, and Consistent Oversight Needed if Regulatory Analysis Is to Help Control Costs of Regulations, GA0/PA0-83-6, November 2, 1982. Available from U.S. General Accounting office, Document Handing and Information Services Facility, Gaithersburg, Maryland 20760.

13. U.S. Nuclear Regulatory Commission, Proposed Policy Statement on Safety Goals for Nuclear Power Plants, USNRC Report NUREG-0880, 1982. Available for purchase from the National Technical Information Service, Springfield, Virginia 22161.

14. U.S. Congress, Pacific Northwest Electric Power Planning and Conservation Act, Public Law 96-501, 94 Statute 2697, 96th Congress, (December, 1980).

15. U.S. Nuclear Regulatory Commission, Regulatory Analysis Guidelines of the U.S. Nuclear Regulatory Commission, NUREG/BR-0058, January 1983. Available for purchase from the National Technical Information Service, Springfield, Virginia 22161.

16. U.S. Office of Management and Budget, Improving Government Regulation: A Progress Report, p. 19, Washington, D.C., 1979.

17. Executive Order 12291, "Federal Regulation," Federal Register, (February 17, 1981). Avatlable in public and technical libraries.

18. U.S. Office of Management and Budget, "Interim Regulatory Impact Analysis Guidance," Washington, D.C., June 12, 1981.

19. U.S. Environmental Protection Agency, "Guidelines for Performing Regulatory Impact Analyses," Washington, D.C., April 15, 1982. Available from the U.S. Environmental Protection Agency, Office of Policy and Resource Management, Washington, D.C. 20003.

20. U.S. House of Representatives, "Regulatory Procedure Act of 1982," H.R. 746, 97th Congress, 2nd Session, 1982.

21. U.S. Regulatory Council, A Survey of Ten Agencies' Experience with Regulatory Analysis, Washington, D.C., 1981. Available from the U.S. Regulatory Council 1, Washington, D.C. 


\section{COST-BENEFIT ANALYSIS IN OTHER FEDERAL AGENCIES}

Cost-benefit analysis is frequently applied by agencies in the public sector to various economic problems. Over the past decade, several agencies have acquired valuable insight and experience in applying the technique to germane issues. These agencies, by advancing their knowledge about cost-benefit analysis, have been able to improve the quality and extent of their analytical efforts. Specifically, applications of the methodology have improved as analysts have become more aware about the importance of monetizing nonmarket factors and including these factors in their analyses.

The andiytical efforts of the NRC are affected by legislation and judicial rulings. Under the National Environmental Policy Act (NEPA) of 1969, the NRC is "directly responsible for evaluating the total environmental impact of nuclear powerplants, and for assessing this impact in terms of the available alternatives for power generation..." (see Ref. 1). This function requires that the NRC evaluate and compare the expected benefits and environmental costs resulting from a proposed nuclear facility. The principal benefit, electric power generation, is easily assigned a monetary value by using a straightforward market valuation estimation procedure. Most costs, however, are usually assessed in nonmonetary terms. Moreover, additional nonmarket benefits associated with the plant (e.g., improved fishing and recreational opportunities at the cooling lake) are not currently monetized by the NRC in the evaluation process. By using appropriate economic valuation techniques, nonmarket costs and benefits can be assigned dollar values.

A number of federal agencies currently use such economic valuation procedures to assess the total impacts of proposed regulations or projects. In addition, several of these agencies have direct roles in the licensing and regulatory evaluation procedures of the NRC. The following sections contain a review of the environmental assessment procedures of four federal agencies. Relevant considerations and implications for the NRC are drawn from this review.

\subsection{The Environmental Protection Agency}

The Environmental Protection Agency (EPA) was established in the Executive branch as an independent agency in December, 1970. Its purpose is to coordinate effective governmental action on behalf of protecting and enhancing the nation's environment. Its principal function is to control and abate pollution in the areas of air, water, solid waste, noise, radiation, and toxic substances. EPA's efforts to control pollution integrate a variety of research, monitoring, standard setting, and enforcement activities. As such, EPA is a regulatory agency responsible for developing, evaluating, and enforcing standards and regulations protecting the environment, and must comply with 
President Reagan's Executive Order 12291* which dictates reform initiatives in the federal regulatory analysis process. The order requires that regulatory agencies send all proposed regulations, along with regulatory impact analyses (RIAs), to the office of Management and Budget (OMB) for review before they are made effective.

The RIA is a specific summary document which presents the results of all analyses conducted on a proposed regulation. OMB is responsible for developing procedures for preparing the RIAs, and has specified five elements which should be contained in the analyses (see Section 2.4.1 of this report).

Section 2 of Executive Order 12291 stipulates that the chosen regulatory alternative must have the least net cost to society and that "Agencies shall set regulatory priorities with the aim of maximizing the aggregate net benefits to society...." EPA has noted that the benefit-cost analysis required for the RIA is founded on the principle of economic efficiency, implying that projects or actions should be undertaken only if benefits exceed costs.

EPA's Office of Policy and Resource Management has coordinated the design of draft procedures (Ref. 4) (to $^{\star \star}$ to and analysts and officers at E.PA in preparing RIAs which satisfy the requirements of OMB. The Draft Guidelines note that in determining the economic efficiency of a proposed regulation, based on a benefit-cost analysis, it is necessary to quantify and value in dollar terms, insofar as possible, the benefits and costs involved in an action's full range of effects. Thus, in an attempt to provide policymakers with information on monetizing and evaluating the effects of proposed regulations, including environmental impacts, the Draft Guidelines outline the factors and methods which should be considered in quantifying benefits and costs and valuing them in dollar terms.

Several offices within EPA (including the Economic Analysis Division; the Office of Air Quality Planning and Standards; the Office of Research and Oevelopment; and the Office of Solid Waste) have undertaken detailed analyses designed to evaluate the impacts of regulatory actions within an econonic, benefit-cost framework. The specific studies conducted by these offices are discussed in Chapter 4, which summarizes the methodologies for monetizing the nonmarket impacts of regulatory actions.

*Executive Order 12291, "Federal Regulation," was issued by President Reagan on February 17, 1981. It is a follow-up to Carter's Executive Order 12044, "Improving Government Regulations," the major change being an emphasis on more analytical provisions (see References 2 and 3 ).

**The initial Oraft Guidelines were prepared by an intra-agency working group under the direction of the Office of Policy and Resource Management. The Draft Guidelines have been refined and presented to the Red Border Review Group of EPA, which is responsible for finalizing and adopting the Guidelines as internal directives to be followed throughout EPA. The Office of Policy and Resource Management will be responsible for seeing that these procedures are complied with in EPA's preparations of RIAs for OMB. 


\subsubsection{Relevance to the NRC}

One of EPA's chief responsibilities in managing and protecting the nation's environment and natural resources is reinforcing the efforts of federal agencies, such as the NRC, with respect to the impact of their operations on the environment. As part of this role, EPA is specifically charged with publishing its findings about an agency proposal that is unsatisfactory from the standpoint of public health, welfare, or environmental quality.

The Office of the Assistant Administrator for Enforcement within EPA provides policy procedures for EPA officials who are responsible for enforcing standards and regulations in pollutant areas pertinent to NRC actions (e.g., air, water, radiation, noise control, and hazardous and solid waste management). EPA's "Draft Guidelines for Performing Regulatory Impact Analyses" direct that the evaluation of environmental regulations be based on benefit-cost analysis, requiring the valuation of environmental impacts in monetary terms when possible. For consistency, the NRC should similarly analyze the economic effects of its regulations and activities, particularly since its actions with respect to environmental impacts are subject to EPA review.

Furthermore, under the Senate and House Regulatory Reform bills currently being considered in Congress, * the NRC may become subject to the regulatory analysis procedures required and enforced by $O M B$, inciuding the preparation of RIAs on proposed regulations. The Draft Guidelines prepared by EPA are explicitly designed to help officials develop RIAs which will meet the regulatory analysis requirements of OMB. Consequently, the RIAs serve as an excellent example of the types of economic analyses which the NRC might have to conduct in evaluating the environmental berefits and costs of regulatory actions.

\subsubsection{Nonmarket Impact Assessment Process}

EPA's Draft Guidelines have been designed specifically to ensure agency compliance with Executive Order 12291 in preparing regulatory analyses. The Executive Order mandates that for every proposed major rule*k both a preliminary and a final RIA must be developed and published in the Federal Register. For all proposed rules, other than major rules, a full-scale RIA is not

* For a more detailed discussion of the proposed regulatory reform measures and their relevance to the NRC, see Appendix A.

* Reference 2 defines a "major rule" as "any regulation that is likely to result in:

1. An annual effect on the economy of $\$ 100 \mathrm{million}$ or more;

2. A major increase in costs or prices for consumers, individual industries, Federal, state or local government agencies, or geographic regions; or

3. Significant adverse effects on competition, employment, investment, productivity, innovation, or on the ability of the United States-based enterprises to compete with foreign-based enterprises in domestic or export markets." 
required -- however, sufficient analysis must be performed to demonstrate that the objectives of the Executive Order (i.e., the criterion of economic efficiency) are met.

The principal goal of the RIA is to identify and evaluate the benefits and costs to society of alternative regulatory actions. For purposes of preparing the RIAs, the analysis of the benefits and costs of a proposed regulation is divided into human health and nonhealth effects. The health effect, one type of nonmarket impact, arises as a result of exposure to various pollutants, causing human illness or mortality. Such substances are classified as:

(1) carcinogens,

(2) toxic noncarcinogens,

(3) teratogens, and

(4) mutagens.

Alternatively, the range of nonhealth effects, another type of nonmarket impact, is very broad and includes:

(1) aesthetic improvements in environmental quality;

(2) preservation of ecosystems and endangered species;

(3) improved agricultural productivity;

(4) enhanced materials performance; and

(5) recreational activities, such as increased sports fishing opportunities.

An assessment of the costs and benefits from a proposed regulation requires measuring the pollutants affecting environmental quality and then determining their impact on the human health and nonnealth factors.

In addition, an assessment of the benefits attributable to proposed regulations involves determining the values that individuals and society place on decreasing the adverse effects of pollution. EPA's Draft Guidelines note that the complexity involved in the assessment of regulatory benefits includes varying degrees of uncertainty, and thus in some cases, upper and lower bound estimates should be prepared in addition to the most likely beneficial results of the regulation. Furthermore, it is stated that the RIAs will vary with regard to the level of detail, quantification, and the degree of certainty they present. "These differences will result from variations in the nature and quantity of underlying data, in the adequacy of the available analytical methodology, and in resource or time constraints, or because the particular environmental problems or control methodologies do not lend themselves to quantification" (Ref. 4). 


\subsubsection{Valuation of Human Health Benefits}

In determining the value of human health factors associated with pollutant reductions, EPA recommends estimating the direct costs (e.g., medical costs, loss of employment and income, and impact on productivity) resulting from illness or morbidity. This estimate, however, represents a lower bound for the value of reducing morbidity since it does not account for the personal costs of pain and inconvenience nor does it include the value of time for sick people who are not members of the work force.

Rather than assign a direct monetary value to the expected number of lives saved due to a regulatory action, the Draft Guidelines direct that implicit values be determined using the following technique:

The monetized benefits of the proposed regulation are to be subtracted from the total costs and this remainder is then divided by the potential number of lives saved -- this value represents the implicit cost per life saved.

The implicit value of potential lives saved is considered in the overall evaluation of benefits and costs. It is recognized in the Draft Guidelines that the net benefit estimated in the strictly defined benefit-cost analysis which examines the economic efficiency based on monetized benefits and costs excludes potentially important effects which could not be assigned a dollar value. Thus, the RIA will include a broader version of the benefit-cost analysis which explicitly describes and evaluates the quantifiable and nonmonetized benefits and costs. It is within this framework that the implicit cost of lives saved is considered, providing the agency's decisionmaker with a useful perspective on the implications of regulation. The Draft Guidelines stipulate that as a general guidance for agency analysts, a proposed regulatory policy is warranted if the cost per life saved does not exceed $\$ 1.5$ million.*

\subsubsection{Valuation of Nonhealth Benefits}

In deriving monetary estimates for the amount individuals would be willing to pay to avoid the nonhealth damages of the pollutants subject to regulation, four techniques are described and recommended by EPA:

(1) direct costs approach: estimates the cost savings to individuals and society resulting from environmental regulation,

* "Some regulations with a higher apparent cost-per-life-saved may be justifjed if other non-market benefits are sufficiently important, or if society is especially risk-averse for that particular type of health impact." (See Reference 4, p. 18.) 
(2) property value approach: uses transaction records and data on a variety of neighborhood characteristics, including environmental, to determine implicit prices for these attributes,

(3) travel cost technique, and

(4) contingent market surveys.

General guidelines are given as to which technique is most applicable for valuing different types of nonmarket impacts.* The choice of the appropriate method depends on the affected groups, the type of nonmarket good, and the relationships between the environmental impact and any related markets. It is noted that if there are few connections with actual markets, the contingent market survey may be the most plausible methodology for monetizing benefits.

\subsubsection{Specific Nonmarket Impact Analysis}

A number of EPA offices have recently conducted studies to analyze the potential benefits from proposed regulations. Several evaluations represent RIAs prepared specifically to meet OMB's requirements for regulatory analysis in compliance with Executive Order 12044 and Executive Order 12291. Of greater interest are the studies conducted with the primary goal of testing and evaluating particular economic methodologies used to assign monetary values to nonmarket impacts. Interest in this area of research is based on EPA's efforts to meet the more stringent analytical techniques and economic efficiency requirements specifically called for in Executive Order 12291, for which the Draft Guidelines have been prepared.

The Economic Analysis Division, within the Office of Policy and Resource Management, has been directly involved in the design and evaluation of the Draft Guidelines. This division is also responsible for providing support to the various agency offices in preparing RIAs, and for reviewing and amending the RIAs before their presentation to OMB. Two studies (Ref. 5 and Ref. 6) funded by the Economic Analysis Division are of special relevance as they deal explicitly with the application and assessment of specific economic valuation techniques.

(1) Pacific Northwest Laboratory completed a study in May, 1982, on the use of the contingent bidding survey to estimate the values of improvements in water quality along the Potomac River. The analysis, based on the responses of 2,000 households, explicitly examined and tested for the presence and magnitude of several types of biases. Results indicated sizeable and statistically significant strategic behavior; differences in the mean bid among households depending upon the information provided; and variations in mean

*For instance, the travel cost method is recommended for estimating the benefits associated with recreational activities. 
elicited bid among individual interviews. Upper and lower bounds to the willingness-to-pay values were estimated.*

(2) A study prepared by Research Triangle Institute (RTI) compared alternative methods for estimating the recreation and related benefits of water quality improvements along a segment of the Monongahela River in Pennsylvania. Three methodologies--travel costs, contingent ranking, and contingent valuation--were used to derive and compare monetary estimates for various recreational use, option and existence values associated with water quality improvements. ${ }^{\star \star}$

The Office of Air Quality Planning and Standards has recently completed a major study (Ref. 7) of the economic benefits associated with the Secondary National Air Quality Standards. This office is currently undertaking another broad and detailed benefits assessment project concerned with the regulations on new sources of air pollution covered under the New Sources Performance Standards.

The 1981 study, Benefits Analysis of Alternative Secondary National Ambient Air Qual ity Standards for Sulfur Dioxide $\left(\mathrm{SO}_{2}\right)$ and Total Suspended Particulates (TSP), examined the beneficial economic impacts of regulations associated with air pollution controls, and provided explicit estimates of selected nonhealth benefits resulting from achieving alternative $\mathrm{SO}_{2}$ and TSP secondary standards. Although nonmarket valuation methodologies, such as the contingent survey technique, were not employed, several indirect market methods for valuing the benefits of achieving the Secondary National Ambient Air Quality Standards were applied. These techniques were hedonic pricing based on the residential property markets, and hedonic pricing based on wage

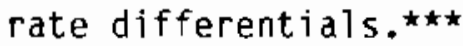

*For specjfic dollar estimates reported in the study, see Chapter 4, Table 4-1, Key Features of Nonmarket Impact Valuation Studies; Cronin (1982)

No. 1 .

* Reference 6 (pp. 8-17) reports the annual user benefit estimates for the following water quality improvement levels:

- Change in water quality resulting in loss of use:

Contingent valuation technique: $\$ 6.58-36.25$

Travel cost technique: $\$ 82.65$

- Change in water quality permitting boating and fishing: Contingent valuation technique: $\$ 4.21-30.88$

Travel cost technique: $\$ 7.01$

- Change in water quality permitting swimming: Contingent valuation technique: \$9.21-50.59

Travel cost technique: $\$ 14.71$

Option values are also reported for the various water quality levels; they were estimated using the contingent valuation technique.

$\star \star \star$ For specific dollar estimates reported in the study, see Chapter 4,

Table 4-1, Key Features of Nonmarket Impact Valuation Studies; Manue1, et a1. (1981) No. 14. 
The Office of Research and Development has conducted numerous studies for developing and evaluating economic methodologies for monetizing nonmarket benefits and costs. The Dffice of Health and Ecological Effects within the Office of Research and Development funded a study (Ref. 8) to develop benefits of environmental quality improvements associated with air pollution controls. The study concentrated on two primary topics:

(1) Experimental techniques for valuing air quality and other environmental improvements were developed and tested for the South Coast Air Basin of southern California;

(2) Analytical economic methodologies were implemented to develop hypotheses on disease etiologies and to value labor productivity and consumer losses due to air pollution-induced mortality and morbidity.

The methodologies used in estimating the benefit values of air quality improvements through pollution controls were the direct market approach based on the residential property market and the contingent market approach based on an interview survey instrument. The study reported the following estimates of people's willingness-to-pay for a $30 \%$ improvement in ambient air quality:

(1) property value technique: $\$ 42.00$ per household per month (1977 dollars);

(2) contingent survey technique: $\$ 29.00$ per household per month (1977 dollars).

Reference 8 ( $\rho .21$ ) cites the following three findings as the fundamental benchmarks derived from the study:

(1) "many benefits traditionally viewed as intangible and thereby nonmeasurable can, in fact, be measured and be made comparable to economic values as expressed in markets;"

(2) "aesthetic experiences and morbidity (illness) effects may dominate the measure of benefits as opposed to previous emphases on mortality health effects;" and

(3) "the likely economic benefits of air quality improvements are perhaps as much as an order of magnitude greater than previous studies had hypothesized."

3.2 The U.S. Fish and Wildlife Service

The U.S. Fish and Wildlife Service (USFWS), a federal agency within the Department of the Interior, is responsible for managing, protecting, and 
issuing regulations pertaining to the nation's fishing, hunting, and wildife resources. The Division of Program Plans (DPP), in the Office of Planning and Budget, performs analytical studies to evaluate USFWS policy options; reviews methodologies for assessing programs involving fish and wildife related resources, including economic valuation techniques; and investigates other factors associated with agency long-term planning. At present, DPP's primary functions focus on the organization, presentation, and analysis of data obtained in the USFWS 1980 National Survey of Fishing, Hunting, and Wildlife Associated Recreation.* This most recent survey consists of three separate questionnaires.

(1) A screening questionnaire, conducted via telephone interviews with 116,025 households nationwide, gathered socio-demographic data for each participating household and identified potential participants (i.e., fishermen, hunters, and/or nonconsumptive wildlife users) for two, more detailed user questionnaires;

(2) In-person interviews, conducted with 32,000 persons identified as hunters or fishermen during 1980, obtained information on participation rates, user days, expenditures, and satisfaction levels for specific hunting and fishing activities, by nation, region, and state. In addition, respondents were asked questions designed to estimate the economic value they placed on these resources.

(3) In-person interviews, involving 6,600 persons identified as nonconsumptive wildlife users, provided information on participation, expenditures, and values for specific nonconsumptive wildlife associated activities on a national and regional basis.

Previous Fishing and Hunting Surveys were designed primarily to obtain participation and expenditure data for fishing and hunting activities, although since 1970 the questionnaires have included data on participation for several types of nonconsumptive wildlife activities as well. In addition to this data, the 1980 Survey will include additional detailed data on more specific nonconsumptive activities, and on values associated with various recreational resources.

DPP has outlined a series of analytical studies to be undertaken utilizing the 1980 data, which identifies eleven project areas and thirty-five specific andytical objectives for current and proposed research, nine of which are directly concerned with estimating and evaluating economic values associated with recreational resources. The development of USFWS's efforts to assign dollar value to types of nonmarket resources such as fishing, hunting, and wildife activities can be associated with several factors:

*The 1980 Survey was conducted by the U.S. Bureau of Census. It is the sixth of such USFWS National Fishing and Hunting Surveys, which have been conducted every five years since 1955 . 
(1) In 1980 the American Forestry Association's National Conference on Renewable Natural Resources, co-sponsored by the International Association of Fish and Wildlife Agencies, of which USFWS is a member, noted that, "Many people believe that fish and wildlife resources are more important economically than is generally granted. Even if true, it has not been proven to the satisfaction of most decision-makers. The economic and social values of these workers have not been well established." The report of the Fish and Wildlife Working Group at the Conference observed that the failure of resource managers to take into account the economic value of nonmarket resources when developing and evaluating resource plans had led to misallocation and mismanagement of resources. A specific recommendation in the Conference Report stated that "The social and economic benefits from recreation need to be quantified to aid decision-makers who must judge the priorities of investments for recreation facilities and services."

(2) The USFWS must comply with the Water Resources Council's (WRC) "Principles and Standards"* (Ref. 9) when preparing federal waterfowl refuge plans. These rules require that all economic, environmental, and social effects (beneficial and adverse) of a plan be considered in the evaluation process, and that all impacts be quantified monetarily wherever possible. Specific economic valuation methodologies recommended in WRC's "Procedures for Evaluation of National Economic Development (NED) Benefits and Costs in Water Resources Planning (Level C)" (Ref. 10) are the travel cost technique and the contingent market valuation technique.

(3) The design of the three survey questionnaires and the review of report formats and preliminary data were conducted by USFWS and four regional technical committees. The committees were established in conjunction with the International Association of Fish and Wildiife Agencies, and included representatives of the state fish and wildife agencies, academicians and other wildlife professionals, and private, nonprofit conservation organizations. The members of these planning committees placed very high priorities on the generation of economic values for fish and wildlife oriented recreational activities for use in national, regional, state, and local resource management decisions.

(4) The USFWS Regional Resource Planning Handbook, published in September, 1981, describes the process to be followed by USFWS Regional Directors in preparing mandatory Regional Resource Plans which identify species of special emphasis; fish and wildife objectives for these species; and a problem analysis and evaluation

* For a detailed discussion of the specifications and requirements of the Principles and Standards, see the Water Resources Council Agency Review in Section 3.4. 
of alternative strategies for meeting the objectives. The handbook stresses that comprehensive planning must evaluate both supply and demand associated with fish and wildife resources. Furthermore, the handbook emphasizes the notion that human (i.e., demand) data is an essential element. The 1980 Survey was designed in part to provide adequate demand data for specific wildlife resources and activities, including estimates of their economic values.

The 1980 Survey was particularly designed to collect and provide the data necessary to conduct the recommended and required types of analytical studies and evaluations described above. Proposed uses of the survey information are:

(1) to provide data with which to conduct the outlined 35 analytical objectives, including the economic valuation assessments;

(2) to serve as a planning tool in the development of USFWS Regional Resource Plans and state fish and wildlife Conservation Plans, in accordance with the Fish and Wildlife Conservation Act of 1980 (Public Law 96-366);

(3) to address current information needs of resource managers for planning, policy analysis and program development.

\subsubsection{Relevance to the NRC}

The USFWS's 1980 National Survey of Fishing, Hunting, and Wildlife Associated Recreation will provide current national, regional, and state data on user participation in fishing, hunting, and nonconsumptive wildlife associated recreation and data on the economic values placed upon these resources by their users.* The Division of Program Plans is conducting various economic analyses utilizing the 1980 Survey Information, based on a set of 35 specific research objectives. Particular studies whose results may be relevant to the informational needs of the NRC include:

(1) developing recreational values for fishing and hunting on a national, regional, and state basis;

(2) generating recreational values for fish and wildlife species and habitats;

(3) evaluating the comparability of economic valuation methodologies (i.e., travel cost method, hedonic travel cost method, willingnessto-pay bidding games) using the economic values generated with each technique;

*The survey data is currently available for purchase from the U.S. Department of Commerce, Bureau of the Census, Data Users Service, Suitland, Maryland. 
(4) assessing the recreational values of nonconsumptive activities on a national and regional basis;

(5) evaluating the economic benefits of fish and wildife associated with recreation to local, state, regional, and/or national economies.

These analyses will provide location specific economic values for detailed fish and wildife related recreational activities. Over 40,000 persons, identified as fishermen, hunters, and nonconsumptive wildlife users, were interviewed, thus allowing for analytical studies based on sample sizes which should produce statistically significant results.

\subsubsection{Nonmarket Impact Assessment Process}

In the data analysis design plan for the 1980 Survey prepared by DPP (Ref. 11), the importance of estimating the economic value of fish and wildlife associated resources is heavily stressed. As noted in the manual, "Studies of the economic values of fish and wildife resources have assumed a high priority in recent years as greater emphasis has been placed upon the cost effectiveness of resource management decisions. Furthermore, it is likely that the need to identify and quantify all resource-related values in economic terms will continue to increase." The efforts of DPP to monetize the recreational values of fish and wildife resources are divided into two types of economic evaluations:

(1) studies of the economic values of fishing, hunting, and nonconsumptive wildlife associated activities on national, regional, and state scales; and

(2) studies of the economic impacts of these activities upon local, state, or regional economies.

The procedure for estimating the economic values of the wildlife associated activities will be based on the user participation, expenditure, and willingness-to-pay data obtained in the detailed user survey questionnaires. Three specific economic valuation methodologies are cited in the data analysis manual as means of generating dollar values:

(1) travel cost,

(2) hedonic-travel cost (a variation of the travel cost technique which estimates the values of specific characteristics of an activity at a given site, based on the cost of travel to that site--such as wildlife density and scenic beauty), and

(3) willingness-to-pay bidding games.

It is noted that the hypothetical nature of the willingness-to-pay bidding game technique can lead to biased responses by the questionnaire participants; 
thus, special attention was placed on the design and administration of the survey, in an attempt to minimize these potential shortcomings.

According to the data analysis plan, a set of state fish and wildlife recreational values would initially be generated, based on a sample of states representing diversity both in location and types of activity. These state value estimates would then be tested on a regional basis, and finally a set of national fishing and hunting recreational values would be generated. The values for nonconsumptive wildlife activities would be estimated using the recommended techniques on a regional and national basis.

Another analytical objective which has been proposed is to test and evaluate the three valuation methodologies by comparing the economic values generated for fishing and wildife related activities utilizing each of the techniques. The large sample size and the comprehensiveness of the 1980 Survey data provide a unique opportunity for comparing and validating the specific methodologies and the generated economic recreational values.

The second aspect of the economic significance of recreational activities is the estimation of the benefits to local, state, and regional economies resulting from the activities. The 1980 Survey provides very detailed information on expenditures for fishing, hunting, and nonconsumptive wildife associated activities which can be analyzed to determine their economic impacts and importance to the regional economy.

Nonmarket resources are associated with recreational activities. Fishing and wildife associated recreational activities for which USFWS must develop and evaluate resource plans, and which are thus addressed in the 1980 Fishing and Hunting Survey, can be disaggregated into two categories: (1) those activities associated with fishing and hunting (i.e., consumptive wildlife uses), and (2) nonconsumptive wildife associated activities. Nonmarket goods included in the first category are:

(1) recreational aspects of animal hunting by group and species, such as:

- big game (deer, elk, moose, bear, wild turkey, caribou, mountain goat, etc.)

- small game (rabbit, quail, squirrel, grouse, pheasant, etc.)

- other animals (woodchuck, raccoon, fox, coyote, lynx, etc.)

(2) recreational aspects of waterfowl and migratory bird hunting by species, such as geese, ducks, doves, pigeons, coots, etc.,

(3) noncommercial aspects of fishing by species, such as bass, pickerel, perch, salmon, steelhead, lake trout, etc.

Types of nonmarket goods associated with nonconsumptive wildlife uses are:

(1) observing, photographing, or feeding particular bird, animal, fish, or other wildlife populations by both individual species and species groupings: 
- birds (songbirds, eagles, hawks, waterfowl, shore birds, pheasant, etc.)

- large animals (deer, elk, bears, coyotes, antelope, moose, etc.)

- small animals (squirrels, chipmunks, rabbits, foxes, raccoons, etc.)

- marine mammals (seals, whales, dolphins)

- butterflies, spiders, and beetles,

- fish (trout, salmon, and other fish)

- reptiles and amphibians.

(2) Participating in recreational activities associated with specific environmental areas which are considered resources in themselves, such as wetlands, ocean beaches, woodlands, marshes, etc.

\subsubsection{Specific Nonmarket Impact Analyses}

In developing and comparing multiple-use management strategies and products integrating several resource categories, USFWS has noted that it is necessary to assess values of wildife in terms that are commensurable with other goods and services (i.e., market commodities). Such an assessment involves expressing these values in dollars, whenever possible, by means of systematic and quantitative methodologies. Various economic valuation studies have been conducted by DPP and the regional fish and wildlife agencies which have produced estimates of recreational values for specific resources and activities. Several of these studies are described below.

(1) Two DPP studies by G. M. Brown et al.* utilized the USFWS 1975

National Survey of Hunting, Fishing, and Wildlife Associated Recreation to estimate dollar values for fish and wildife recreation. One study utilized the hedonic price methodology to estimate marginal values for an additional day or bag (i.e., catch) of eleven specific wildife resources associated with hunting, freshwater fishing, and saltwater fishing activities. $\star$ In the comparison paper, Brown et al. estimated marginal values for a day and bag of 18 specific wildlife resources using the willingness-topay responses from the 1975 Survey. These estimates were compared

\footnotetext{
*G. M. Brown, J. J. Charbonneau, and M. J. Hay, "The Value of Wildlife Estimated by the Hedonic Approach," Working Paper No. 6, U.S. Fish and Wildlife Service, Washington, D.C., March 1978. The companion paper to this is G. M. Brown et al., "Estimating Values of Wildlife: Analysis of the 1975 Hunting and Fishing Survey," Working Paper No. 7, U.S. Fish and Wildlife Service, Washington, D.C., March 1978.

** The eleven wildlife resources for which values were estimated are deer, other big game, upland birds, other small game, waterfowl, other migratory birds, trout, and landlocked salmon, sea-run fishing, bass, other freshwater fishing, and saltwater fishing. For specific values, see Chapter 4, Table 4-1, Key Features of Nonmarket Impact Valuation Studies, Brown, et al. (1978), No. 2 .
} 
to those generated using the hedonic price methodology, and the factors contributing to the lower willingness-to-pay were discussed.

(2) The USFWS California-Nevada Area Office, Sacramento, California, has published two studies prepared by P. A. Meyer (Ref. 12 and Ref. 13) which provide value estimates for varjous fish and wildlife groupings in California's Central Valley area. In Reference 12 Meyer implemented the contingent valuation technique, based on the USFWS 1975 National Hunting and Fishing Survey willingness-to-pay data, to generate the following recreational values:

- River salmon and steelhead fishing: $\$ 28$ per day;

- Other fishing: $\$ 65$ per day;

- Waterfowl hunting: $\$ 42$ per day;

- Migratory bird hunting: $\$ 50$ per day.

Annual value estimates for seven types of wildlife-associated recreational activities for the entire San Francisco Bay area were also generated, both in willingness-to-pay values and in willingness-to-sell, or compensatory, values. Reference 13 estimated recreational values associated with four wildlife species groups* based on a contingent market valuation technique. Approximately 1,500 in-person interviews were conducted in California's Central Valley area to gather information on people's willingness-to-sell values for the specific wildlife resources. These compensatory estimates were reported by species group on both a per household per year and a total Central Valley value per year basis.**

(3) The USFWS Western Regional Agency in Portland, Oregon, funded a study*t* to estimate the value of the salmon and steelhead population lost to Northwest fisheries due to hydroelectric development and operation in the Upper Columbia River Basin. The focus of the study was to discuss and evaluate management decisions which would achieve a balance between fish and power production in the basin such that net social benefits would be maximized. One of the essential factors for deriving the optimal mix of the two resources involved the estimation of the economic value of various salmon and steelhead species to commercial and sport fishers, and thus the economic costs associated with their loss in the Columbia River Basin due to hydroelectric production.

* The four species groupings evaluated were songbirds, water and shore birds, migrating fish, and animals using natural cover.

**The specific economic estimates are reported in Chapter 4, Table 4-1, Key Features of Nonmarket Impact Valuation Studies, Meyer (1980), No. 38. $\star \star \star$ Northwest Resource Information Center, Inc., "Questions of Balance: Columbia River Basin Anadromous Salmon and Steelhead - Hydroelectric Energy," Eagle, Idaho, March 1982. 


\subsection{The Bonneville Power Administration}

The Bonneville Power Administration (BPA), an agency of the Department of Energy located in Portland, Oregon, is responsible for the marketing and management of electric power in the Pacific Northwest (i.e., Oregon, Washington, Idaho, and Western Montana). Its primary functions are to purchase and supply electric power, on a wholesale basis, to public and cooperative utilities, to certain federal agencies, and to several direct service industrial customers (primarily aluminum factories).

Under the recently passed Pacific Northwest Electric Power Planning and Conservation Act (Regional Act), BPA has the authority to acquire new power conserving resources, direct-application renewable resources, and power generating resources in order to meet its power supply requirements. The Pacific Northwest Electric Power and Conservation Planning Council (Planning Council) was established pursuant to the Regional Act as an independent agency responsible for developing a regional conservation and electric power plan. The plan is to include a methodology for determining quantitative environmental costs and benefits in accordance with the requirements of the Regional Act. The Planning Council represents the advisory agency responsible for determining the procedure for evaluating any electric energy resource proposed for acquisition by BPA. When the procedure is adopted, via the regional energy plan, BPA will serve as the implementing agency responsible for conducting the specific evaluations. In the interim prior to the adoption of the plan, BPA must still prepare a statement defining the need, availability, reliability, and system cost of a proposed energy resource, including an assessment of its environmental impacts, in accordance with the Regional Act.

Prior to the Regional Act BPA had only been required, under NEPA, to identify and quantitatively evaluate the environmental impacts associated with power acquisitions. The new standards set forth under the Regional Act, however, require that BPA assign quantitative values, preferably monetary values, to environmental changes, to the extent possible, based on the time, cost, and methodological practicality of the impact valuation procedure.

\subsubsection{Relevance to the NRC}

In accordance with the Regional Act, the Planning Council is currently conducting a study to identify and evaluate current methodologies for quantifying and pricing environmental costs and benefits associated with alternative electric power resource options. One of the energy options under consideration in the study is a large scale (800-1000 MW) Nuclear Light Water Reactor. First and second order environmental impacts attributable to the construction, operation, and retirement of a nuclear plant have been identified.

\footnotetext{
*Acquisition in this sense refers to the responsibility of marketing and transmitting the power associated with such resources: BPA does not possess the right to either own or operate the power generating facilities themselves.
} 
A preliminary specification of the significant impacts has been completed. The first order impacts have been identified as radioactive air emissions and water pollutants, waste disposal, land use, safety, and community aspects. The associated second order impacts are human health, habitat and population changes, public infrastructure, and recreation. The final report will contain recommended methodologies for quantifying these environmental impacts, including a discussion of the availability and quality of the necessary data. The study is being conducted in close coordination with BPA since BPA must implement the evaluation procedures and economic methodologies which the Planning Council adopts on the basis of the project's findings.

\subsubsection{Nonmarket Impact Assessment Process}

During the period 1976-1977 BPA issued a notice of insufficiency in meeting system load demand without an expansion of their power load sources. This notice served as a stimulus for the Regional Act, Public Law 96-501, enacted in December, 1980. This act granted BPA the right to acquire new conservation resources, direct-application renewable resources, and power generating resources. Moreover, the act mandated that those resources which are determined to be cost-effective are to be given priority.* System cost, an important element of cost-effectiveness, includes all direct life-cycle costs of a resource and the quantifiable environmental costs and benefits which are directly attributable to the resource.** The Planning Council is responsible for developing the regional energy plan which will outline a detailed procedure for estimating a resource's cost-effectiveness, including specific methodologies to be used in pricing environmental costs and benefits by BPA. Until this regional energy plan is adopted, BPA is following guidelines detailed in its "Draft Procedures for Estimating Resource Cost Effectiveness, March 1982," which includes the procedure for estimating the environmental costs and benefits. The Planning Council was expected to finalize its procedure for estimating environmental impacts in September, 1982, at which time BPA would be responsible for implementing this plan.

Under the Regional Act, BPA is required to identify all environmental impacts directly attributable to a proposed resource, and, to the extent possible,

*Cost-effective, as defined in Section 3(4) of the Regional Act, refers to a resource which is forecast to be reliable and available within the time frame needed, and which will meet or reduce the electric power demand load placed on BPA at an estimated incremental system cost no greater than that of the least-cost similarly available and reliable alternative resource.

**It should be noted here that all nonquantifiable environmental impacts must be identified as well, but are not directly factored into the determination of cost-effectiveness. These nonquantifiable impacts, deemed as such by $B P A$, are still subject to the requirements of NEPA which specifies that all impacts (direct, indirect and cumulative) of a proposed action that could affect the physical, biological, and socioeconomic environment be included in an analysis. Thus, a resource which is determined as cost-effective must still satisfy NEPA's requirements before it can be acquired. 
evaluate the impacts in a quantitative framework. The environmental impacts in question do not include direct costs associated with safety regulation requirements or mitigation actions (such as the erection of a $f$ ish ladder at a hydropower facility), which are included in the project costs. Rather, the environmental impacts of concern are those residual effects which are not accounted for in project costs, such as the cost associated with the value of fish loss due to the hydropower plant, in spite of the fish ladder. The types of impacts which might result from BPA's acquisition of power resources* include:

(1) emissions affecting both air and water quality;

(2) physical and aesthetic changes associated with alterations of land patterns;

(3) changes in recreational resources;

(4) noise pollution attributable to windmill operation;

(5) effects on flora, fish, and wildlife, including their habitats;

(6) resulting effects on human health and nonhealth characteristics.

As outlined above, the Regional Act dictates that all environmental impacts directly attributable to the acquisition of a power resource be evaluated prior to BPA's acquisition of that resource. The Planning Council is currently developing such a procedure for adoption as the regional energy plan, which BPA will be responsible for implementing. The Planning Council's efforts are discussed in detail in Section 3.3.2.2. In the interim, BPA is following its Draft Procedures outlined in Section 3.3.2.1.

\subsubsection{Interim Procedures}

Section H. of the Draft Procedure, "Procedure for Estimating the Environmental Costs and Benefits," requires the identification of all environmental changes attributable to each proposed resource acquisition. The BPA environmental and economic staff will determine the costs and benefits corresponding to these changes. The changes are categorized by:

(1) environmental benefits and costs which can be estimated using generally accepted market prices;

(2) environmental benefits and costs for which BPA deems there are no generally accepted prices, but for which prices can be imputed using specific methodologies and techniques;

*Resources that BPA may acquire include power sources generated from either hydroelectric or thermal (i.e., coal or nuclear) power plants, power provided through solar generation, and power saved through conservation efforts such as indoor weatherization programs and building code requirements. 
(3) environmental benefits and costs for which no generally accepted prices have been recommended or can be imputed, either because there are no acceptable techniques* or the estimation would be too costly to compute, but which can be quantified in physical units or other appropriate measures;

(4) environmental benefits and costs which BPA determines are nonquantifiable, but which must be identified and evaluated under NEPA requirements.

Those environmental impacts which are assigned prices by BPA are included in the estimation of a project cost factor for each proposed resource. This cost measure is an important factor in determining the cost-effectiveness of the resource, although it is not the only criterion. Environmental impacts which are quantified but not priced are also considered in the cost-effectiveness assessment; therefore, a resource may be deemed cost-effective by BPA without necessarily having the lowest estimated project cost.

The procedures outlined in BPA's interim Draft Procedure for pricing relevant environmental impacts are quite general. Those benefits and costs which can be assigned economic value directly will be done so based on either widely accepted market prices or on administratively established prices such as the range of unit-day values for recreation set by the Water Resources

Council.** The decision to impute prices for those environmental benefits and costs which have no direct market price will be made by officials at BPA, and will depend upon the significance of the impact, the cost of the valuation study, the acceptability of appropriate techniques, and public comment. Although no specific methodologies have yet been recommended by BPA, references have been made to travel cost, hedonic cost, and contingent market studies. As BPA acquires experience in quantifying environmental effects associated with specific resource acquisition proposals, the agency will publish a summary of the specific methodologies and assumptions found to be most applicable in the Federal Register.

\subsubsection{Proposed Procedures}

Section 4(e)(2) of the Regional Act specifies that the Planning Council recommend methodologies to be used in estimating quantifiable environmental costs and benefits directly attributable to the acquisition of proposed resources. The Planning Council is conducting a study entitled, "Quantification of Environmental Costs and Benefits," which will identify and evaluate preferred methodologies for quantifying environmental impacts. The study will propose a stepwise procedure for applying the methods to analyze alternative electric energy supply resources. This procedure will then be applied to two hypothetical case studies-a coal-fired power plant and a small hydro project.

\footnotetext{
*Any environmental impact can potentially be valued economically using an appropriate methodology.

$\star \star$ See Section 3.4 which reviews procedures of the Water Resources Council.
} 
The Planning Council has already finalized three of the seven sections of the study. Task 1 consists of developing a taxonomy of first and second order environmental impacts associated with each of thirteen electric power resource options.* The first order effects consisted generally of pollutant emissions, generated wastes requiring disposal, land requirements, and population changes induced by the construction or operation of a new facility. These effects are then linked to second order impacts representing the consequences felt by human, plant and animal populations. The latter effects are grouped into three categories: physical, biological, and socioeconomic environmental impacts. Seven generic second order impacts were then selected as representative of the major environmental impacts attributable to the thirteen resource options. The impacts chosen were:

(1) visibility impairment from air pollutants;

(2) human health effects;

(3) vegetation damage resulting from certain pollutants;

(4) fish/wildlife population or habitat changes;

(5) materials corrosion; soiling;

(6) outdoor recreational changes;

(7) public infrastructure impacts, e.g., "boom town" effects.

Table 3-1 presents an illustrative example of the taxonomy linking the nuclear resource option with its impacts. The first order impacts attributable to the construction, operation, and retirement of a nuclear power plant are radioactive air emissions and water pollutants, waste disposal, land use, safety, and community impacts. These impacts are then directly correlated with second order and higher order impacts. From this table, the relatively important second order impacts are observed to be human health, habitat and population changes, public infrastructure, and recreation.

Task 2 of the Planning Council's study involved the identification and evaluation of current technologies for quantifying the environmental costs and benefits associated with the above impacts. Primary emphasis is given to those methodologies for assigning dollar values to environmental changes, although several methods for quantifying impacts in physical/biological terms were also considered.

*The thirteen power resource options, by category, are: 1) conservation-weatherization; 2) renewable--hydro, solar, biomass, wind, and geothermal; 3) high efficiency--cogeneration, waste heat/resource recovery, combined cycle, and fuel cells; and 4) conventional--coal, nuclear, and combustion turbines. 
Table 3-1 Taxonomy of Impacts

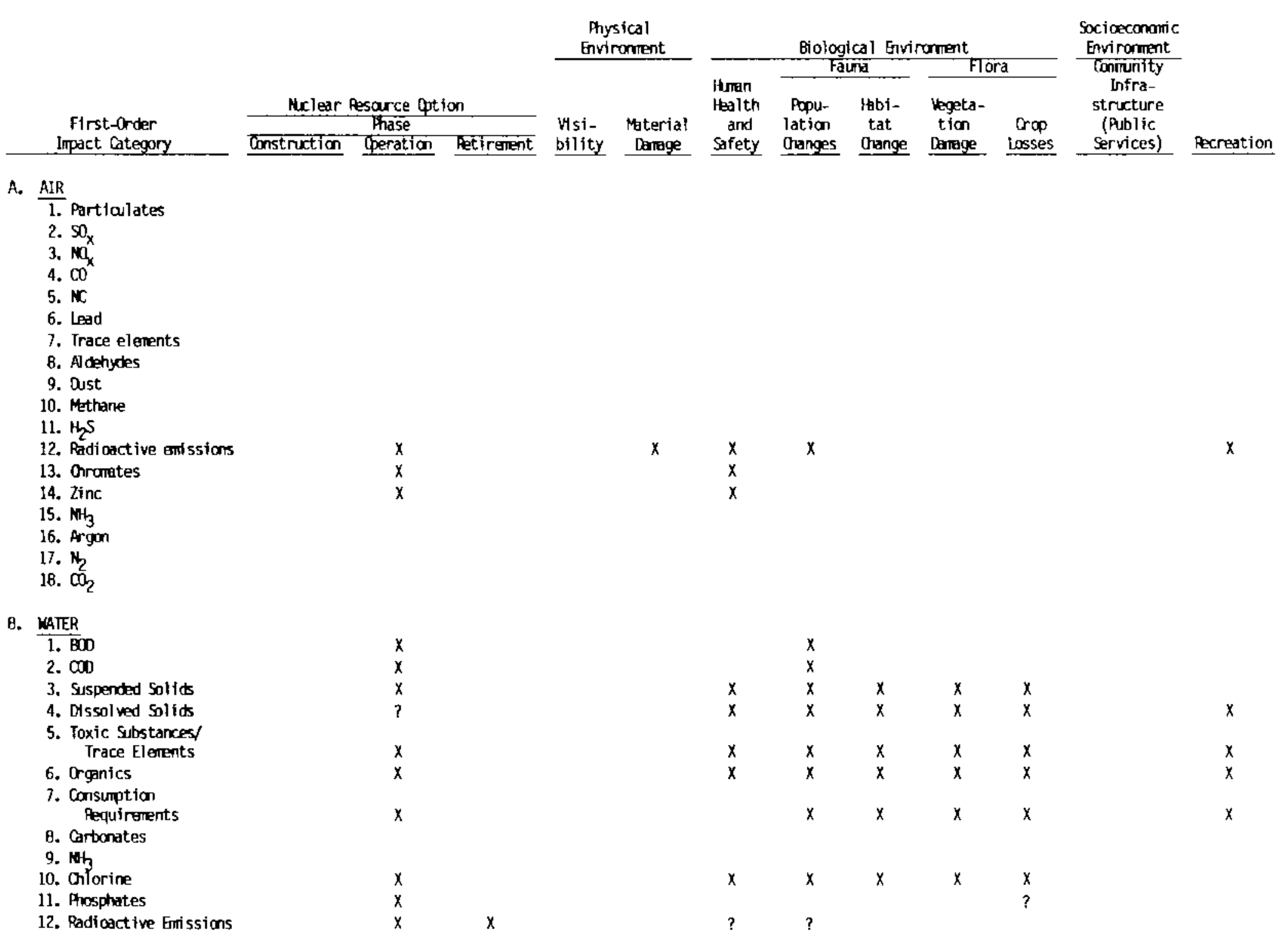


(Table 3-1, continued)

\begin{tabular}{|c|c|c|c|c|c|c|c|c|c|c|c|c|}
\hline \multirow[b]{3}{*}{$\begin{array}{l}\text { First-Order } \\
\text { Impact Category }\end{array}$} & & & & \multirow{2}{*}{\multicolumn{2}{|c|}{$\begin{array}{c}\text { Physical } \\
\text { Envilorment }\end{array}$}} & \multicolumn{5}{|c|}{ Biological Envroment } & \multirow{3}{*}{$\begin{array}{c}\text { Socioeconomic } \\
\text { Envirument } \\
\text { Community } \\
\text { lnfra- } \\
\text { structure } \\
\text { (Prolic } \\
\text { services) } \\
\end{array}$} & \multirow{3}{*}{ pecreatior } \\
\hline & & & & & & \multirow{2}{*}{$\begin{array}{l}\text { Human } \\
\text { tealth } \\
\text { and } \\
\text { sofety } \\
\end{array}$} & \multicolumn{2}{|c|}{ Fauma } & \multicolumn{2}{|c|}{ Flora } & & \\
\hline & Construtton & $\begin{array}{l}\text { esource Qp } \\
\text { Phase } \\
\text { peration }\end{array}$ & Petirement & $\begin{array}{l}\text { Wsi- } \\
\text { bility }\end{array}$ & $\begin{array}{l}\text { Materlal } \\
\text { Lemage }\end{array}$ & & $\begin{array}{l}\text { Popu- } \\
\text { lation } \\
\text { Ohanges }\end{array}$ & $\begin{array}{l}\text { Pabi- } \\
\text { tat } \\
\text { Gange }\end{array}$ & $\begin{array}{l}\text { Negeta- } \\
\text { tion } \\
\text { Demege } \\
\end{array}$ & $\begin{array}{l}\text { Crop } \\
\text { Losses }\end{array}$ & & \\
\hline \multicolumn{13}{|l|}{ C. LAND } \\
\hline $\begin{array}{l}\text { 1. Use/Requirentents } \\
\text { 2. sol fo woste, inc. }\end{array}$ & $x$ & $x$ & $x$ & & & & & $x$ & $x$ & $?$ & $x$ & $x$ \\
\hline nuclear waste & & $x$ & $x$ & & & $x$ & $?$ & ? & ? & $?$ & & \\
\hline 3. aher & & $x$ & $x$ & & & & & & & & & \\
\hline D. NOISE & $?$ & & & & & $?$ & & $?$ & & & & $?$ \\
\hline E. SAFETY & & $x$ & & & & $x$ & & & & & & \\
\hline F. INOUCED POPUMTION GROTH & $\begin{array}{l}x \\
\text { FIRST OR }\end{array}$ & ER IMPACT & TRIX & & Fron & ANO HIO & ER ORJER & $\stackrel{x}{x}$ & & & $x$ & $x$ \\
\hline
\end{tabular}

$\bar{x}=$ Presence of an inpact

$?$ = Possibitity of an lmpact, enendent upon factors such as capacity, location, etc.

Saurce: Nero and Assoctates, Inc., "Stuaty Hodule VI Quantification of Enviromental costs and Beneftts: Task 1: Taxonony of Impacts," figures 13 and 15 , June 14,1982 
The three economic approaches identified and evaluated are:

(1) contingent valuation surveys,

(2) direct costs: estimating value by determining the direct cost of avoiding the environmental impact (also termed defensive expenditures), and

(3) hedonic prices.

The remainder of the project will focus on recommending which of the above methods are most appropriate for quantifying the seven major impacts. The project will also contain two jllustrative case studies. Until these results are adopted by the Planning Council, BPA is evaluating environmental impacts based on its Draft Procedures.

\subsubsection{Specific Nonmarket Impact Analyses}

BPA has undertaken several resource evaluation studies in accordance with the requirements of the Regional Act. The most recent analysis, "Decision Record for the City of Idaho Falls Hydroelectric Project" (March, 1982), identified and evaluated the environmental impacts associated with BPA's acquisition of electric power from three hydroelectric generating plants being rehabilitated and operated by the city of Idaho Falls, Idaho.

BPA is currently evaluating a decision to adopt a conservation program for residential indoor weatherization efforts. Under the Regional Act the environmental impacts from this action must be identified and evaluated.

\subsection{The Water Resources Council}

The Water Resources Council (WRC) was established as an independent executive agency by the Water Resources Planning Act of 1965 (Public Law B9-80, 42 U.S.

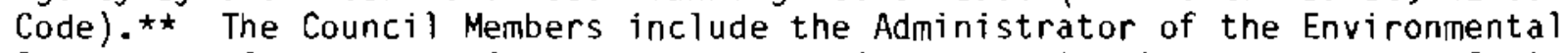
Protection Agency, the Attorney Ceneral of the Justice Department, the Chairman of the Office of Management and Budget and the Council on Environmental Quality, and the Secretary of each of the following Departments: Agriculture, Army, Commerce, Energy, Housing and Urban Development, Interior, and Transportation. The purpose of WRC is to develop a comprehensive and effective policy, in accordance with the Water Resources Planning Act, to encourage conservation, development, and utilization of water and related-land resources. One of its primary functions includes establishing principles,

\footnotetext{
* See the literature review in Chapter 4 for a detailed discussion of these methods.

**President Reagan's 1981 Budget terminated funding for WRC in September 1981. A Cabinet Council on Natural Resources and the Environment, which includes the Water Resources Working Group, has since been established.
} 
standards, and procedures for federal agencies in the formulation and evaluation of federal water and related-land resources projects.

Initial Principles and Standards (P\&S) were published by WRC in 1973. The P\&S provided for uniformity and consistency in formulating alternative plans and in measuring and comparing their beneficial and adverse effects. Four components or accounts were established to evaluate project efforts:

(1) national economic development, (2) environmental quality, (3) regional economic development, and (4) social well-being. The first two accounts, upon which the primary considerations in the decision-making process were to be based, were designated as coequal national objectives to be optimized in project planning. The last two components were designed to include additional relevant information which would be displayed but which would not bear major significance in the project evaluation process.

However, lack of designated procedures for valuing the beneficial and adverse effects of the plans led to variations in the evaluation techniques used by federal agencies and, in some cases, to the use of incorrect measures for project costs and benefits. A 1978 Presidential memorandum directed WRC to evaluate federal agency procedures for conducting benefit/cost analyses, and to develop and publish a planning manual with a uniform set of Procedures ensuring that benefits and costs be estimated in monetary units, where possible, and in a consistent and accurate manner using the best current evaluation techniques.

As a result of the memorandum, the 1973 P\&S were revised in 1979, and published as a Final Rule in 1980 (see Ref. 9). As a Final Rule, they are enforceable by a third party through the federal court system. The major revisions include:

(1) clarifying the principles and standards;

(2) integrating the requirements of the National Environmental Protection Act (NEPA) into the planning framework

(3) specifying procedures for preparing and evaluating each of the four accounts.

To date, the Procedure for Evaluation of National Economic Development (NED) Benefits and Costs (18 CFR Part 713) and the Environmental Quality (EQ) Evaluation Procedure (18 CFR Part 714) have been developed and published as Final Rules.** The NED procedures incorporate the traditional cost-benefit analysis, whereas the EQ evaluation procedures are designed to insure that

\footnotetext{
*The memorandum is entitled, "Improvements in the Planning and Evaluation of Federal Water Resources Programs and Projects."

**PNL has provided copies of these Procedures to NRC. PNL's short working paper, contained in Appendix C, relied, in part, on these procedures.
} 
nonpriced or unquantified environmental amenities and values be given appropriate consideration in decision-making along with economic considerations, as required by NEPA.

The planning process requires that alternative plans be formulated and evaluated with respect to a proposed project. The set of alternative plans includes: (1) a plan which maximizes net beneficial NED effects, i.e., a plan which maximizes the net priced beneficial effects, (2) a plan which maximizes net beneficial EQ effects, and (3) a primarily nonstructural plan. Displays are to be prepared for each of the plans which identify and measure the effects in each of the four accounts. Each of the plans is then appraised, and a decision is made either to recommend a plan or to select none of the alternative plans. The recommended plan must have combined beneficial NED and EQ effects which outweigh the combined adverse NED and EQ effects.

\subsubsection{Relevance to the NRC}

Over a period of nine years, WRC has developed and refined a broad policy framework for federal agencies in preparing and evaluating water and relatedland resources projects.* These efforts have culminated in the publication and adoption of a set of procedures for estimating the beneficial and adverse effects of alternative plans and for selecting a recommended plan. Four major provisions of the procedures are summarized below.

(1) The P\&S have established two coequal national objectives to be optimized in developing and selecting project plans. All beneficial and adverse effects which can be valued monetarily, including environmental impacts, are to be included in the NED account; the EQ account should contain those residual environmental effects which are described in nonmonetary units, either quantitatively or qualitatively. The priced effects are to be estimated using specific methods to insure that the impacts are assessed accurately and consistently within the framework of the traditional costbenefit analysis.

(2) Currently, the selected plan must have an estimated benefit/cost ratio greater than one, based on the combined beneficial and adverse effects of both the NED and EQ accounts. The proposed Principles and Guidelines, which were to become effective in late 1982, mandate that that plan be selected which optimizes the monetary net beneficial effects, i.e., those comprised in the NED account, subject to environmental constraints such as NEPA.

*Initial Principles and Standards were published by WRC in 1973; these were revised in 1979 and again in 1980. Procedures for estimating NEO and EQ effects were published in 1979 and 1980. A reformulation of these rules was expected to be adopted in late 1982, as Principles and Guidelines. 
(3) The general measure for assigning dollar value to the effects of a proposed plan is defined as the willingness of users to pay for the additional output attributable to each plan. Many of the effects cannot be estimated using the actual demand generated for the incremental output. Thus, WRC has specified four methods which are to be used in obtaining the monetary estimates of the effects of a plan:

- willingness to pay based on actual or simulated market price;

- change in net income;

- cost of the most likely alternative; and

- administratively established values, published periodically by WRC.

(4) The P\&S have further specified and recommended several economic methodologies to be used in deriving dollar estimates of nonmarket impacts. Two demand estimating techniques, the travel cost method and the contingent market valuation method, have been recommended as the preferred methodologies. The Procedures for Evaluating NED Benefits and Costs provide criteria by which to choose the most appropriate method. A discussion of data requirements, survey techniques, and detailed evaluation designs is included for each technique. The procedures also strictly limit the use of the unitday value method, based on judgmental estimates of the average value of a "recreation day." The potential use of this method depends on the significance of the impacts; the magnitude of the proposed project; and the cost and time required to perform the analysis.

\subsubsection{Nonmarket Impact Assessment Process}

The P\&S published in the Federal Register (Ref. 9) describe in detail the process federal agencies must follow in formulating and evaluating water resources plans. Four accounts have been established which encompass all of the significant, beneficial, and adverse effects of proposed and alternative plans. Each of the accounts pertains to particular aspects of the effects:

(1) National Economic Development (NED)--contains all effects on the national economy, based on changes in the value of quantifiable goods and services;

(2) Environmental Quality (EQ)--contains effects on the ecological, cultural, and aesthetic attributes of significant natural and cultural resources which cannot be monetized and included in the NED account;

(3) Regional Economic Development (RED)--shows the regional incidence of the NED effects, income transfers, and employment effects; 
(4) Other Social Effects (OSE)--contains urban and community impacts on life, health, and safety.

By definition, all effects which come under the NED account are to be expressed in monetary units, representing the change in the value of the national output associated with the project under evaluation. All impacts categorized in the $E Q$ account represent changes in the physical environment which are not assigned monetary value, but are expressed either in quantitative (i.e., numeric) units or through quality indicators which describe the desirability of a resource and the degree to which each plan affects the particular resource. Effects in the RED and OSE accounts may be expressed in either monetary, numeric, or non-numeric terms.

The current P\&S, the Procedures for the evaluation of NED benefits and costs, and the Procedures for the evaluation of beneficial and adverse effects on environmental quality have been adopted by WRC and published in the federal Register. The specific federal agencies which must legally comply with these procedures in the planning and evaluation of federal water resources projects are:

(1) The U.S. Army Corps of Engineers (Civil Works)

(2) Water and Power Resources Services

(3) Tennessee Valley Authority

(4) Soil Conservation Service

(5) National Park Service, Heritage Conservation and Recreation Service, and Forest Service water-oriented National Recreation Areas

(6) Fish and Wildife Service.

The NED account identifies beneficial effects associated with the increase in:

(1) the value of goods and services, broken down into ten specific categories; *

(2) the value of output resulting from external economies;

(3) the value associated with the use of otherwise unemployed or underemployed labor resources.

*The ten categories in which to evaluate the effects of goods and services are: municipal and industrial water supply; agricultural floodwater, erosion, and sedimentation; agricultural drainage; agricultural irrigation; urban flood damage; power (hydropower); transportation (inland navigation); transportation (deep draft navigation); recreation; and commercial fishing. 
The value of goods and services is defined as the willingness of users to pay for each increment of output resulting from a plan. In many cases, it is not possible to measure actual demand for these outputs. As a result, WRC has identified four alternative techniques for estimating the total value of output associated with a plan:

(1) willingness-to-pay based on actual or simulated market price;

(2) change in net income;

(3) cost of the most likely alternative;

(4) administratively established prices.*

Several specific methodologies have been referred to and fully discussed in the procedures for estimating the benefits of nonmarket impacts, particularly those associated with recreational services provided by a plan. Two demand estimating models, the travel cost method and the contingent valuation method, have been recommended as preferred techniques over the unit-day value method, which is based on judgmental estimates of the average value of a "recreation day." The procedures include criteria to guide in the selection of the apropriate method and explicitly limit the use of the unit-day method.

The adverse effects which are specified in the NED account are the opportunity costs of the resources used in implementing a plan. The opportunity costs should reflect the full economic value of the resource to society, and where market prices do not account for the full costs, associated costs (such as the cost of displaced recreational use at a project site) are to be recorded.

The evaluation framework for appraising the beneficial and adverse effects in the $E Q$ account outline a four-phase procedure for assessing the quantitative and qualitative impacts, but specific measurement techniques are not included. The first phase identifies the EQ resources and their attributes which will be affected by the plan and evaluated, and specifies how they will be described or analyzed in the EQ evaluation process. The second phase collects and presents information for use in evaluating the effects of the proposed and alternative plans, including the existing and forecasted conditions of the resources. The third phase describes the effects of the plans on each of the resource attributes in terms of duration, location, and magnitude, and determines the significance of these effects. The last phase includes methods for appraising each of the plans in terms of the significance of the beneficial and adverse effects, and specifies that the decision-making agency is responsible for determining each plan's overall net effect on EQ, to be judged as "net beneficial," "net adverse" or "no net effect."

\footnotetext{
*Administratively established prices are values for specific goods and services explicitly set by WRC, such as the range of unit-day values for recreation.
} 
The effects associated with the NED and OSE accounts are evaluated only in the display section of the planning evaluation, and are not measured against the effects of the national objective accounts ( $i . e, N E D$ and EQ). However, they are still considered as important components of project evaluation whose effects must be clearly and fully presented for all alternative plans.

The nonmarket effects associated with proposed water and related-land resources plans fall primarily within the NED and EQ accounts. * The impacts are reported and evaluated in each of the two national objective accounts based on the measure chosen for evaluating their effects. A partial list of the environmental impacts expressed in nonmonetary terms (i.e., those which comprise the EQ account) include:

(1) effects on plant and animal species populations and habitats;

(2) changes in the chemical and physical properties of air, water, and soil;

(3) effects on perceptual, aesthetic attributes of the environment such as pristine landscapes, historic monuments, forests, and cultural resources.

It would be possible, however, to estimate monetarily the benefits and costs associated with these environmental effects using appropriate, theoreticaliy sound economic methodologies, thus enabling their inclusion in the NED account.

Nonmarket impacts which are explicitly evaluated within the cost-benefit framework of the NED account include the benefits resulting from increased recreational services, such as fishing, swimming, hunting, and hiking. The costs associated with the loss or reduction of recreational activities must also be estimated and included within the NED account evaluation.

In the Federal Register (September 21, 1981), a notice of the proposed repeal of the P\&S and the Procedures for evaluating the beneficial and adverse NED and $E Q$ effects was published by WRC. These rules are currently being reformulated and amended by the Cabinet Council on Natural Resources and the Environment as Principles and Guidelines, which will replace the rules currently in

\footnotetext{
*The OSE account specifies the following as the four impact categories which are to be evaluated in the display for each plan:

- urban and community impacts;

- life, health, and safety factors;

- energy requirements and energy conservation

- long-term productivity.

Specific nonmarket impacts include changes in the quality of community life, risks associated with natural disasters affecting people's security, and environmental effects not detailed in the other accounts. The effects are reported as either beneficial or adverse, and are quantified where possible.
} 
effect. The major changes in the procedures for preparing and evaluating water and related-land resources projects are:

(1) The P\&S (18 CFR Part 711) would be replaced by Principles and Guidelines, and as such would no longer be enforceable by third party groups.

(2) There would be only one primary national objective - that of national economic development (NED) - which would be optimized subject to environmental constraints consistent with national environmental statutes and federal requirements, such as NEPA.

(3) All four accounts would still exist and be considered in the evaluation process, but only the NED account would necessarily be displayed.

(4) The list of agencies covered by the Principles and Guidelines would be limited.

(5) The Procedures for evaluating the effects in the NED and EQ accounts would be incorporated into guidelines; the Procedures for evaluating NED and OSE effects would not be completed or adopted.

(6) The selection rule would change: the current P\&S mandate that the selected project must have a benefit/cost ratio greater than one. The proposed guidelines specify that the project having the optimal net beneficial NED effects, subject to the EQ constraints is to be chosen.

These proposed Principles and Guidelines are currently being reviewed, and will be presented to the President for approval before their adoption by the Cabinet Council. The responsibility for improving, revising, and implementing the new guidelines will be undertaken by the Cabinet Council's Water Resources Working Group, comprised of the members of WRC in addition to several newly appointed members.

\subsubsection{Specific Nonmarket Impact Analyses}

Since the adoption of the WRC Manual of Procedures for Evaluation of National Economic Development (NED) Benefits and Costs (December 1979), the U.S. Army Corps of Engineers, Buffalo District, has prepared and evaluated a beach erosion control project for protection and recreational enhancement of Presque Isle Peninsula, Erie, Pennsylvania, using the travel cost technique to estimate the recreational benefit value of the project. A very detailed procedure was used to derive estimates for the projected use of the enhanced beach sites over a fifty-year period. The estimation procedure incorporated direct travel costs and the opportunity costs of time spent in travel and in "recreating" at the beach sites. By considering the full economic costs, including the cost associated with congestion, the benefits derived from the increased usage of the beaches due to the enhancement project were estimated. 


\subsection{References}

1. U.S. Congress, National Environmental Policy Act of 1969, Public Law 91190. 63 Statute 852, 91st Congress, January, 1970.

2. Executive Order 12291, "Federal Regulation," Federal Register, (February 17, 1981). Available in public and technical Tibraries.

3. Executive Order 12044, "Improving Government Regulations, "Federal Register, (March 23, 1978). Available in public and technical libraries.

4. U.S. Environmental Protection Agency, "Guidelines for Performing Regulatory Impact Analyses," Oraft Report, Washington, D.C., April 15, 1982. Available from the U.S. Environmental Protection Agency, office of Policy and Resource Management, Washington, D.C. 20003.

5. F. J. Cronin, Valuing Nonmarket Goods Through Contingent Markets, PNL4255/UC-11. Prepared for the U.S. Environmental Protection Agency, Washington, D.C., September 1982. Available from Pacific Northwest Laboratory, Energy Systems Department, Richland, Washington 99352.

6. Research Triangle Institute, A Comparison of Alternative Approaches for Estimating Recreation and Related Benefits of Water Quality Improvements. Prepared for the U.S. Environmental Protection Agency, Washington, D.C., 1982. Available from Research Triangle Institute, Research Iriangle Park, North Carolina 27709.

7. U.S. Environmental Protection Agency, Benefits Analysis of Alternative Secondary National Ambient Air Quality Standards for Sulfur Dioxide and Total Suspended Particulates, Research Triangle Park, North Carolina, 1981. Available from U.S. Environmental Protection Agency, office of Air Quality Planning and Standards: Benefits Analysis Program, Research Triangle Park, North Carolina 27709.

B. D. S. Brookshire, T. D. Crocker, R. C. d'Arge et al., Methods Development for Assessing Air Pollution Control Benefits, Volume $\sqrt{\text {, Executive }}$ Summary. Prepared for the U.S. Environmental Protection Agency, Washington, D.C., 1979. Available from the U.S. Environmental Protection Agency, Office of Research and Development, Washington, D.C. 20002.

9. U.S. Water Resources Council, "Principles and Standards for Water and Related Land Resources Planning - Level C; Final Rule," Federal Register, Volume 45, No. 190, (September 29, 1980). Available in technical and public libraries.

10. U.S. Water Resources Council, "Procedures for Evaluation of National Economic Development (NED) Benefits and Costs in Water Resources Planning (Level C)," Federal Register, Volume 44, No. 242, (December 14, 1979). Available in technical and public libraries. 


\section{A REVIEW OF METHODS AND ESTIMATES FOR VALUING NONMARKET GOODS}

Determining the values associated with environmental changes has become more important as more extensive regulations by government agencies have imposed increased costs on all sectors of the economy. With greater frequency, society is asking the question, "Do the benefits of regulating impacts on nonmarket goods exceed the costs?" Increasingly, therefore, state and federal laws and regulations require agencies to consider the environmental costs and impacts of their actions. For example, the National Environmental Policy Act (NEPA) requires the Federal government to prepare an Environmental Impact Statement (EIS) of virtually any power plant siting or construction action. In response to the Calvert Cliffs decision, a cost-benefit analysis which considers balancing environmental and economic tradeoffs of the facility and various alternatives is to be included in the EIS.

As the courts attempt to balance environmental and economic considerations, methods which estimate the economic damages associated with environmental impacts become more important. These methodologies allow dollar values associated with physical and biological damages to be estimated and thereby place both costs and benefits in commensurate units.

The following section briefly discusses and critiques eight potential methods. These methods are divided into two parts: those methods relying directly on market data and those methods relying only indirectly on market data. These indirect methods are further divided into those which view nonmarket goods as complements in consumption (e.g., hedonic price function and travel cost methods) and those which rely on contingent techniques (e.g., bidding, adjustment, allocation, direct utility, and ranking). An illustrative set of criteria against which to evaluate techniques for valuing nonmarket goods is offered. Finally, the key characteristics of over forty prior studies valuing environmental goods, including the estimated dollar value, are presented. These characteristics are summarized in Table 4-1 at the end of this chapter.

In essence, techniques for valuing nonmarket goods are generally inferential procedures. That is, since the values of such goods are, by definition, inadequately reflected in the functioning of economic markets, the economist must play the role of detective and infer the values society "attaches" to these goods.

A proper evaluation would require: (1) a sound foundation in theoretical welfare economics; (2) an understanding of nonmarket goods (e.g., ecological systems); (3) an understanding of how impacts affect nonmarket goods and (4) a set of criteria, both theoretically appropriate and practical, with which to evaluate candidate methodologies.

\subsection{Measuring the Value of Environmental Changes}

This section discusses and briefly critiques potential illustrative candidate methodologies for valuing environmental changes. Several techniques 
11. U.S. Fish and Wildife Service, The 1980 National Survey of Fishing, Hunting, and Wildlife-Associated Recreation: A Plan for Data Analysis, Wastington, D.C., February 1982. Available from the U.S. Fish and Wildlife Service, Office of Planning and Budget, Division of Program Plans, Washington, D.C.

12. P. A. Meyer, "The Value of Fish and Wildlife of San Francisco Bay - A Preliminary Survey," U.S. Fish and Wildlife Service, the California Water Policy Center, Sacramento, California, August 1979.

13. P. A. Meyer, "Recreational/Aesthetic Values Associated with Selected Groupings of Fish and Wildlife in California's Central Valley," U.S. Fish and Wildlife Service, Sacramento, California, November 1980. 
previously employed by researchers or discussed in the literature are not reviewed due either to their inherent and unknown biases (e.g., damage response functions or delphi techniques) or their inability to produce estimates in monetary terms (e.g., voting). Candidate methodologies are divided into those which can be valued directly from market data and those which can only be valued indirectly.

\subsubsection{Measuring Values Directly}

When nonmarket goods enter into the production process as factor inputs, changes in these nonmarket goods may lead to changes in the costs of production, the price and quantity of output, and the returns to other factors of production. With information on the costs of production, output supply conditions, and product demand, changes in such observable market data can be used to estimate the value of changes in the nonmarket good. Obviously, acquiring such information may be costly. In certain situations, however, the estimation of benefits may be relatively straightforward.

For example, where the nonmarket good is a near perfect substitute for other factor inputs, and this relationship is known, the value of the change in the nonmarket good can be calculated quite easily.* In other cases where changes in nonmarket goods are likely to accrue to producers, benefits may be estimated from changes in factor incomes.

Three studies on commercial fisheries have employed this tract in valuing changes in ecological systems (see Ref. 1, Ref. 2, and Ref. 3). The relationship between biological productivity and water quality was estimated and used to estimate the value of water pollution abatement. For example, Bell and Canterbery (Ref. 2) estimated the benefits of improved marine fisheries associated with reaching the goals of the Federal Water Pollution Control Act Amendments of 1972. After determining the biological productivity--fish catch--water quality relationships, the authors employed demand models to compute changes in consumer surplus following supply-induced price changes.

\subsubsection{Measuring Values Indirectly}

In this section, two general techniques for estimating the value of environmental changes indirectly are discussed. The first views environmental goods as an input into a household production function. The second comprises the general area of contingent techniques.

\subsubsection{Nonmarket Goods as Household Inputs}

Discussion of this area will focus on two techniques which have a long history and extensive literature. These are the travel cost technique and the hedonic technique.

\#If marginal cost and output are not affected, this estimate is accurate; if marginal cost and output are affected, a bounded approximation can be obtained. 
The travel cost technique (TC). Based on the early work of Clawson (Ref. 4), Knetsch (Ref. 5), Clawson and Knetsch (Ref. 6) and later extensions, a substantial body of literature has attempted to estimate the value of recreational activities or projects from data on travel costs to recreational areas.*,** Researchers have attempted to overcome the problem of constant recreation fees by inferring how consumers would respond to changes in recreation fees by analyzing how consumers "respond" to variations in travel

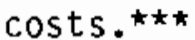

Researchers have extended the original Clawson-Knetsch (CK) model in five basic areas. First, researchers have generalized the concept of travel costs from the earlier definition of out-of-pocket expenditures to include the opportunity cost of time both in travel to the site as well as in time spent at the site (Ref. 12 and Ref. 13). Second, researchers have also generalized the concept of cost to include the cost of capital of complementary goods (e.g., boats, trailers) used in the production of recreation services by the consumers. Third, researchers have generalized the model to include more than one site--the original CK model made no reference to the supply prices of alternative sites. In the Timit, when a new site appears with lower travel costs, the $C K$ model implies zero consumption at the old site, i.e., the shape and level of demand curves at all sites are constant (Ref. 14). Explicit inclusion of alternative sites was undertaken by Burt and Brewer (Ref. 16); Cesario (Ref. 17); Cesario and Knetsch (Ref. 18); and Cicchetti, et al., (Ref. 10). Fourth, researchers have extended the model to include the impacts of congestion (see Ref. 19 and Ref. 20).t Allen and Stevens (Ref. 24) discuss the problems in estimation when the model is misspecified due to the failure to include variations in congestion. Finally, the original CK model has been extended from its initial focus on current users of a site to include the response of a population to changes in environmental amenities. Burt and Brewer (Ref. 16), Brown and Nawas (Ref. 25), and Gum and Martin (Ref. 26) have employed samples of regional populations, allowing the response of nonusers of the site to be estimated.

*The travel cost method can be formalized within the theory of household production developed by Becker (Ref. 7), Lancaster (Ref. 8) and others. See D. Brown (Ref. 9); Cicchetti et al. (Ref. 10); Deyak and Smith (Ref. 11); McConnell (Ref. 12); McConnel1 and Strand (Ref. 13); and Vickerman (Ref. 14).

$\star \star$ For a review of this literature, see Freeman (Ref. 15).

$\star \star \star$ Since this does not provide an income-compensated demand curve, the estimated benefit, Marshallian consumer surplus, would be an approximation to the true compensating variation measure.

tFor analyses of the effects of congestion on wilderness recreation use and benefits, see Fisher and Krutilla (Ref. 21) and Cicchetti and Smith (Ref. 22). McConnell (Ref. 23) and Deyak and Smith (Ref. 11) have estimated the effects of congestion on recreation behavior. 
While the travel cost method has been greatly improved from its initial specification and has been widely employed, the strong assumptions underlying its structure (e.g., that of weak complementarity which requires the individual to be indifferent to all nonsite aspects of his trip), the difficulty of applying the technique to specific environmental characteristics or changes in these characteristics, the problem of specifying crucial variables (e.g., the value of time and total travel cost), the limited applicability of the method (e.g., the method is not applicable to recreation sites without significant travel costs-as those near urban areas) and the problem of estimating nonuser benefits (e.g., existence value) severely restrict the usefulness of the method. Finally, some researchers have raised the issue of instability of results. For example, using essentially the same data, Cesario and Knetsch (Ref. 18) and Cesario (Ref. 17) employed the travel cost method and obtained substantially different benefit estimates.

The hedonic technique. Since Ridker and Henning's (Ref. 27) seminal article, an extensive literature has developed which attempts to estimate households' willingness-to-pay for environmental goods based on the hedonic price function (HP).* This technique, a concept originally developed by Court (Ref. 29), posits a relationship between the price of a good and its constituent characteristics (e.g., between housing value and the characteristics of housing such a number of bedrooms, ambient air quality, etc.). Economists have used this technique to estimate the value of wildlife, and the value of air, water and noise pollution abatement. ** The fundamental assumptions necessary for the estimated function to provide the marginal willingness-to-pay for the $q^{\text {th }}$ environmental good are:

(1) that the market be in equilibrium;

(2) that consumers be able to perceive the characteristics of the consumption good, including the environmental aspects;

(3) that information and transactions costs be zero and that deviations from equilibrium be corrected instantaneously; and,

(4) that a complete range of the good with alternative characteristics be available.

While no assumptions are ever strictly maintained, numerous studies, particularly in the urban economics literature with respect to the housing market--the predominant area of hedonic applications--have raised serious

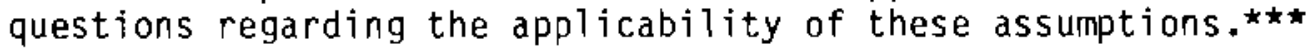

\footnotetext{
*The hedonic price technique can be formalized within the theory of household production developed by Becker (Ref. 7) and Lancaster (Ref. 8).

$\star \star$ See Freeman (Ref. 28).

$\star \star \star$ For example, with respect to the housing market, see Cronin (Ref. 30 and 31$)$.
} 
If one accepts the assumptions, however, the partial derivative of the hedonic price function is the marginal implicit price or, since the market is assumed to be in equilibrium, the marginal willingness-to-pay for the characteristic under consideration.* For valuing nonmarginal changes, an inverse demand function must be estimated. This requires obtaining implicit prices for each consuming unit (by appropriately selecting the functional form for the hedonic price function) which would then be related to the levels of the environmental good "consumed." Harrison and Rubinfeld (Ref. 33) have estimated such models for air pollution abatement.

While the hedonic technique has several strengths (e.g., readily available secondary data especially for housing market or labor supply studies; a consistency of estimation results (Ref. 34, pp. 156-160); a theoretical ability to value highly specific attributes of nonmarket goods; and a good approximation to a theoretically correct welfare measure if the underlying assumptions are not seriously violated), the method is also plagued by inadequacies. For example, consumers must perceive the nonmarket characteristics under evaluation; benefits accruing offsite from the consumption good under evaluation are not valued (e.g., in residential housing studies, nonmarket benefits accruing at the workplace are not considered); detailed secondary data may be required; temporal and spatial synchronization of data for both effluents and consumption goods are necessary; and the market must be correctly defined.

At present, the economics profession is divided over the ability of the hedonic technique to value nonmarket environmental goods. For example, Maler (Ref. 35) states that "it is next to impossible to get meaningful estimates of benefits from environmental improvements" from hedonic studies of the residential housing market. Randall (Ref. 36) agrees. However, a large body of economists disagrees with such summary dismissals.

A potential innovative application that PNL is examining combines the hedonic view of consumption characteristics of a good with the contingent bidding approach.** Results of this investigation will permit direct comparisons between the benefits of water quality improvements and costs (the latter from engineering studies) of changes in chemical characteristics of water.

\subsubsection{Nonmarket Goods Valued Through Contingent Methods}

Five areas are discussed here. These are: the contingent bidding method; the contingent adjustment method; the expenditure allocation method; the direct utility method; and the contingent ranking method.

\footnotetext{
* See Rosen (Ref. 32) for a discussion of this point. If all of the necessary assumptions of the HP method are met, the technique would generate a Bradford bid curve and thus a compensating measure of value.

**F. J. Cronin, "Determining the Implicit Prices of the Chemical Characteristics of Water Quality," Pacific Northwest Laboratory, Richland, Washington, 1983 (forthcoming).
} 
The contingent bidding method. The contingent bidding (CB) method is a direct inquiry technique which attempts to value nonmarket goods by directly asking individuals to state their maximum willingness-to-pay (WTP) for an environmental improvement or their minimum willingness-to-accept compensation (WTA) for an environmental degradation. The CB method can be structured to obtain theoretically correct measures of welfare for any given system of property rights-a characteristic especially important in attempting to value a condition contrary to the status quo.

During the past decade, economists have made substantial refinements to the $C B$ method. The technique has been used to value visual aesthetics, ozone depletion, wildijfe, fishing and hunting, resource development (both recreational and industrial), air quality, water quality (both in terms of uses and characteristics as well as chemical specifications), increments and decrements in stream flows, and congestion.

Fundamental to the use of contingent market techniques are the assumptions that:

(1) consumers value the hypothesized changes being "made" in the contingent market;

(2) such changes can be depicted by researchers using various stimuli;

(3) consumers comprehend the stimuli presented by the researchers;

(4) consumers will accurately determine the value to them of the hypothesized changes; and finaliy,

(5) consumers will accurately reveal these values.

Numerous questions remain unanswered, however, regarding potential biases in contingent market analysis.* Primary among these biases are hypothetical, strategic, information, and interviewer.

Hypothetical Bias. Hypothetical bias reflects the fact that the respondent knows that he is merely "playing a game." There is no a priori reason to expect the person to reveal his true value or preferences in such a game if the alternatives presented to the individual appear unrealistic and unreasonable (Hebert et a1., Ref. 37). Bishop and Heberlein (Ref. 38) present evidence based on actual cash payments versus revealed values from contingent market techniques that support the need to construct reasonable and realistic alternatives.

Strategic Bias. Strategic bias is an attempt by the respondent to influence the outcome of the bid process by revealing a bid other than his true valuation. This might result from the respondent's understatement of his true

*For a discussion of these questions, see Hebert, et al. (Ref. 37). 
valuation based on the belief that his share of the project's cost may be in proportion to his expressed valuation; on the other hand, a respondent's belief that his cost share will be lower than his expressed valuation might induce an overstatement of expressed valuation (i.e., attempt to become a free-rider). Although recent studies have casually dismissed the importance of strategic bias, * the only study until recently to systematically examine this issue is that by Bohm (Ref. 43). Bohm finds that within an experimental approach employing actual cash payments, strategic behavior did not exist; however, within an experimental approach employing contingent (i.e., hypothetical) bids, statistically significant bias did exist. Cronin (Ref. 46), employing an experimental design explicitly structured to test for strategic bias, confirms this.

With respect to testing for strategic bias, both Bohm (Ref. 47) and Brookshire, Ives and Schulze (Ref. 45, p. 345) recommend employing an experimental design structured to induce strategic bias**--similar to the study recently undertaken by Cronin.

*For example, Thayer (Ref. 39, p. 27) states that "strategic behavior has been widely studied and generally found to be nonexistent;" Greenley, Walsh and Young (Ref. 40, p. 662) write, "It is noteable that objections to the contingent valuation approach have been primarily theoretical, as empirical evidence of systematic bias is at best inconclusive;" Rowe and Blank (Ref. 41), conclude, "Strategic biases are of ten cited as potential reasons why respondents will misstate their true valuations... Several bidding method studies and other related research have examined and tested for this behavior in WTP processes. Other than for obvious problem bids, it has never been found."; and Schulze, d'Arge and Brookshire (Ref. 42, p. 156) state, "Empirical evidence thus far does not support the existence of strategic bias among consumers." In fact, Schulze et al. (Ref. 42) incorrectly reference Bohm (Ref. 43) as supporting the conclusion of the nonexistence of strategic bias, when in fact the opposite is true of Bohm (Ref. 43). The fact that two prior articles involving Schulze and Brookshire, i.e., Rowe, d'Arge and Brookshire (Ref. 44) and Brookshire, Ives and Schulze (Ref. 45), not only raise the importance of strategic bias, but also correctly reference Bohm (Ref. 43) for support, only adds to the confusion.

* In fact, the article by Brookshire, Ives and Schulze (Ref. 45) appears to take contradictory positions on the issue of strategic behavior. The authors correctly interpret the findings in Bohm (Ref. 43) and suggest a split sample experimental design to induce and test for strategic behavior. The authors, however, attempt to detect strategic behavior in their own sample by comparing the distribution of elicited bids with some a priori assumed population bid distribution. Since the population distribution of actual bids is unknown, the procedure produces unknown results. In addition, the sample consists exclusively of recreators at a lake--a sample with potentially homogeneous preferences. 
Besides having no direct tests of strategic behavior other than Bohm (Ref. 43) and Cronin (Ref. 46), prior inferences regarding the existence and impact of such behavior have been largely drawn from studies relying on small homogeneous samples of recreators or residents of recreationally oriented areas. For example, Thayer (Ref. 39) and Brookshire, et a1. (Ref. 48) both employ recreators while Rowe et al. (Ref. 44) and Brookshire, Ives and Schulze (Ref. 45) employ residents and recreators. In terms of sample size, Thayer employs a useable sample of 106, Brookshire, Ives and Schulze a useable sample of 84 and Rowe et al. a total sample of 119 .

Information Bias. Information bias refers to any of the potential biases introduced by the survey design or information available to the respondent. Three specific components of information bias have been discussed in the literature: information, starting point and payment vehicle. Rowe, d'Arge, and Brookshire (Ref. 44) find that the elicited bid varies with the information provided to the respondent, the suggested starting bid, and the payment mechanism. Similar findings are presented in Brookshire, Ives and Schulze (Ref. 45) with respect to starting bid and with respect to payment mechanism, in Greenley, Walsh, and Young (Ref. 40). Contrary findings with respect to all three components are offered in Brookshire, et al. (Ref. 48) and with respect to information and starting point in Thayer (Ref. 39).

It appears that the preponderance of researchers who have analyzed the issue, conclude that a payment mechanism bias does exist, that is, that respondents are not indifferent to the mechanism of payment (assuming liability rules and costs are identical). Daubert and Young (Ref. 49, p. 672) offer the interesting supposition that payment vehicle bias may actually reflect strategic behavior on the part of households, particularly, users of recreational activities. In fact, results presented in Randall, Ives and Eastman (Ref. 50); Rowe, d'Arge and Brookshire (Ref. 44); Daubert and Young (Ref. 49); and Greenley, Walsh, and Young (Ref. 40) indicate that households altered their bid in response to the payment vehicle in a manner consistent with strategic behavior.

Interviewer Bias. Probably the least investigated source of bias is that due to variations among the interviewers conducting the interview (obviously, in a mail-in questionnaire, this bias would not exist). Few researchers acknowledge the potential problem and fewer still report any attempt to test for the presence of such a bias.* Two studies reporting such tests (Ref. 39 and Ref. 51) both report no indications of a bias due to variations among interviewers. The former study, however, states (p. 39) that only "simple distributional analysis" was employed, while the latter study gives neither information on quantitative results nor on how the hypothesis was tested.

\footnotetext{
*Possible explanations of the lack of attention given the potential bias due to variations among interviewers may be economists' lack of experience in surveying techniques and the very small sample usually employed in such contingent studies.
} 
The economics profession is divided over the validity of contingent bidding methods. For example, Freeman (Ref. 34, pp. 104-105) dismisses the method. On the other hand, Mishan (Ref. 52) concludes:

Surveys based on the questionnaire method may be suspect for a number of reasons, but they are sometimes better than guesswork, and assuredly better than no data at all. The economist in earnest in making cost-benefit analysis a more discriminating technique will be giving plenty of thought to the measurement of environmental spillovers and, in consequence,...to the possibilities of evolving questionnaire techniques for eliciting critical information.

In fact, PNL has recently conducted two contingent bidding studies: one on visual aesthetics (see Ref. 53) and another on improvements in water quality (see Ref. 46). The latter analyzed the responses of 2000 households, one of the largest surveys ever conducted using this technique. The analysis explicitly examined and tested for the presence and magnitude of strategic, information and individual interviewer bias using an expenditure function, the inverse of an indirect utility function. Results indicated sizeable and statistically significant strategic behavior, differences in the mean bid among households depending upon the information provided, and variations in mean elicited bids among individual interviewers. Upper and lower bounds of the true but unobservered WTP were estimated.

The contingent adjustment method. Instead of asking individuals to indicate their willingness-to-pay for a given quantity of a public good, as in the contingent bidding method, consumers could be asked to indicate their preferred quantity of a nonmarket good, given the relative prices of the goods being considered. Such studies are called contingent adjustment (CA) models. Such studies have been conducted by Randall et al. (Ref. 50), Rowe et al. (Ref. 44) and by Thayer (Ref. 39). The latter study involved a contingent travel cost methodology.

The strengths and limitations of contingent evaluation techniques apply to this method, just as they do to contingent bidding techniques.

The expenditure allocation method. The expenditure allocation method (EA) is a direct inquiry technique that requires primary data collection. Variations on this approach have been employed by Hardie and Strand (Ref. 54) and stated by David Brookshire in private communication (University of Wyoming, Laramie, Wyoming, October 12, 1979). Although the purpose of these empirical studies was not to estimate demand curves for nonmarket goods, these studies indicate the expenditure allocation approach is feasible.

PNL has been exploring potential applications of the EA method to valuing nonmarket goods. In fact, PNL has outlined how the procedure could be applied to valuing such goods as visual aesthetcs. Furthermore, PNL has extended the underlying structure of the EA model to allow consumers to allocate their "budget" to private goods. 
While the EA method suffers from the limitations common to all contingent methods and an increased complexity of questionnaire design and administration, the method has several strengths. Among these are a theoretically correct benefit measure; a requirement that the respondent consider the hypothetical nonmarket change relative to potential changes in other nonmarket goods, private goods and disposable income; a determination of the relative values among public and private goods; and, a reduced opportunity for strategic behavior by the respondent.

Direct utility method. In 1974, Sinden (Ref. 55) presented a method for deriving the recreation demands of consumers based on cardinal utility functions and indifference maps. This approach is based on the Ramsey method involving a game where a subject is asked to choose between two nonmarket opportunities, or prospects. Every prospect contains two outcomes, each of which has a specific probability associated with it. One of the four outcomes is varied until the subject is indifferent between the prospects. This information is used to define a point on a cardinal utility curve. The game is repeated by varying the outcomes associated with each of the prospects in order to derive additional points on the utility curve. Ordinary least squares methods are used to fit a utility function to the indifference points revealed through the Ramsey game. Given information about consumer budgets and expenditures on the different recreation opportunities, the fitted utility function is optimized subject to a recreation budget constraint. The demand curves for the relevant prospects are then derived parametrically by varying the implicit price of each nonmarket opportunity over a range of values.

The major drawback to this approach is that the interviews required to obtain indifference maps, budget, and expenditure information are relatively lengthy--more than an hour per subject. As a result, Findlater and Sinden (Ref. 56) have devised a simpler, faster method of obtaining indifference maps, known as the probabilistic rating method. Comparisons between the two methods suggest that the newer method has improved performance characteristics over the Ramsey approach.

The Contingent Ranking Method. The use of contingent ranking procedures for valuing environmental goods has been a very recent development.* This procedure holds that individuals' valuation of environmental goods can best be estimated by presenting individuals with a set of alternatives-each alternative describes a specific state of the world by characterizing the good's features and cost to the individual under the specified conditions. Individuals are then asked to rank the alternatives from most to least preferred. The implicit assumption of the contingent ranking approach is that individuals are more likely to accurately order hypothetical combinations of

*D.A. Rae, "The Value of Visitors of Improving Visibility at Mesa Verde and Great Smokey National Parks." Paper presented at the Visual Values Workshop, Keystone, Colorado, May 11-13, 1982. Also see Reference 57. 
environmental goods and fees than to directly reveal their willingness-to-pay for specified changes in any of these goods. To operationalize this procedure, a random utility function specification of household behavior-which shifts attention from an intensive choice margin and associated incremental analysis to individual decision-making at an extensive margin with discrete selections--is combined with an assumed stochastic probability distribution.

Four issues present potential problems to the successful application of this method. (1) Due to the very recent development of this procedure, estimation techniques are not readily available.* (2) The researcher is forced to assume the independence of irrelevant alternatives--that is, that the odds of one alternative being chosen over a second alternative are not affected by any other alternatives. This means that alternative sets cannot contain close substitutes. (3) The relationship between the structure of the random utility function and assumptions regarding optimizing behavior by individuals needs to be carefully considered, particularly the role of prices. $\star \star$ (4) Finally, the results of the few studies to date are, at best, mixed. Results obtained from these applications were inconsistent with theoretical implications, counterintuitive and fraught with highly questionable data manipulation and ad hoc model specification.

\subsection{Some Suggested Criteria for Evaluating Candidate Methodologies}

In this section, some suggested criteria with which to evaluate candidate methodologies are discussed. The presentation is limited to a listing of suggested criteria and an expanded discussion of Criterion 1. Criteria are not necessarily listed in order of importance.

(1) It is necessary that the technique be based on a theoretically appropriate measure of value. In other words, is the technique based on standard microeconomic precepts of consumer welfare? If the technique does not produce estimates of theoretically appropriate welfare measures, strictly defined, can known, bounded approximations of reasonably close estimates be obtained?

*If the determinants of the random utility function are known and models linear in parameters are employed, a maximum likelihood estimator such as modified multinominal logit can be employed.

**For example, while Rae describes his welfare measure as a compensating variation (e.g., the change in income required to hold utility constant), it is actually the change in the fee that must accompany a change in visibility to hold utility constant. The specification is also inconsistent with an interpretation as an indirect utility function. 
For example, Willig (Ref. 58) addressed the issue of approximating theoretically correct welfare measures from changes in prices with Marshallian ordinary consumer's surplus. Randall and Stoll (Ref. 59) extended Willig's analysis to the case of changes in quantities. From the results of this research, one can conclude that where the environmental good under consideration is not unique, is not associated with a large income effect, and payment of the good's value would not take a substantial proportion of income, measures which produce Marshallian demand curves provide reasonable approximations of the more theoretically appropriate Hicksian welfare measures. On the other hand, where these conditions do not hold, Hicksian welfare measures should be used.

Furthermore, as Randall (Ref. 36) demonstrates, in most cases it does not matter whether the measure sought is willingness-to-pay (WTP) or willingness-to-accept compensation (WTA) since one can be calculated from the other. However, in the case of a threatened environmental good which is especially unique and treasured, it is essential to use willingness-to-accept compensation.

(2) It is necessary that the technique under consideration produce an estimate of value in monetary terms. This is consistent with accepted standards of economic benefit-cost estimation.

(3) It is necessary that the technique permit a proper identification and valuation of the relevant environmental change under consideration.

(4) It is necessary that the valuation technique relate changes in the environmental good to changes in consumer's behavior and finally to changes in welfare measures.

(5) It is necessary that empirical variables correspond to theoretical variables.

(6) It is necessary that appropriate statistical techniques be matched with the theory and data.

(7) What are the costs of prototype value estimation?

(8) What are the costs of implementation of the technique after prototype development?

(9) Are consistent estimates obtained with the technique?

(10) Are plausible estimates obtained with the technique? 
Table 4-7 Key Features of Nonilarket Impact Valuation Studies

\begin{tabular}{|c|c|c|c|c|c|c|c|c|c|}
\hline Author and Date & Topic & Sponsor* & $\begin{array}{l}\text { Value } \\
\text { Method }\end{array}$ & $\begin{array}{c}\text { Collection } \\
\text { Method }\end{array}$ & Subjects & Sample & Base Year & Site & Value \\
\hline 1. Cronin (1982) & $\begin{array}{l}\text { Water } \\
\text { Quality }\end{array}$ & EPA & $\begin{array}{l}\text { Contingent } \\
\text { Bidding }\end{array}$ & $\begin{array}{l}\text { Personal } \\
\text { Interview }\end{array}$ & Residents & 1509 & 1973 & $\begin{array}{l}\text { Potomac } \\
\text { River }\end{array}$ & $\$ 33$ to 105 phpa \\
\hline 2. Darling & $\begin{array}{l}\text { Recreation } \\
\text { Aesthetics }\end{array}$ & -- & $\begin{array}{l}\text { Hedonic- } \\
\text { Property }\end{array}$ & $\begin{array}{l}\text { Personal } \\
\text { Interview }\end{array}$ & Residents & -- & -- & $\begin{array}{l}\text { Oakland, } \\
\text { San Diego, } \\
\text { Santee }\end{array}$ & -- \\
\hline $\begin{array}{l}\text { 3. Desvousages } \\
\text { et al. (1982) }\end{array}$ & $\begin{array}{l}\text { Water } \\
\text { Quality }\end{array}$ & EPA & $\begin{array}{c}\text { Travel Cost } \\
\text { Contingent } \\
\text { Valuation }\end{array}$ & $\begin{array}{l}\text { Personal } \\
\text { Interview }\end{array}$ & Residents & 384 & $\ddot{1981}$ & $\begin{array}{l}-- \\
\text { Monongahela } \\
\text { River }\end{array}$ & $\begin{array}{l}\$ 83 \mathrm{pa} \\
\$ 50 \text { to } 120 \mathrm{phpa}\end{array}$ \\
\hline & & & $\begin{array}{l}\text { Contingent } \\
\text { Ranking }\end{array}$ & & & & -- & -- & -- \\
\hline \multirow[t]{2}{*}{$\begin{array}{l}\text { 4. Feenberg \& } \\
\text { Milis (1980) }\end{array}$} & $\begin{array}{l}\text { Water } \\
\text { Quality }\end{array}$ & EPA & Hedonic & $\begin{array}{l}\text { Census } \\
\text { Tract }\end{array}$ & Residents & 506 & 1970 & $\begin{array}{l}\text { Boston } \\
\text { Beaches }\end{array}$ & $\$ 0.21$ pepa \\
\hline & & & Travel Cost & $\begin{array}{l}\text { Personal } \\
\text { Interview }\end{array}$ & Users & 464 & 1974 & $\begin{array}{l}\text { Boston } \\
\text { Beaches }\end{array}$ & $\$ 1.17 \mathrm{pcpa}$ \\
\hline $\begin{array}{l}\text { 5. Gramltch } \\
(1977)\end{array}$ & $\begin{array}{l}\text { Water } \\
\text { Quality }\end{array}$ & & $\begin{array}{l}\text { Contingent } \\
\text { Bidding }\end{array}$ & $\begin{array}{l}\text { Telephone } \\
\text { Interview }\end{array}$ & Residents & 165 & 1973 & $\begin{array}{l}\text { Charles } \\
\text { River }\end{array}$ & $\$ 31$ phpa \\
\hline $\begin{array}{l}\text { 6. Greenley } \\
\text { et al. (1981) }\end{array}$ & $\begin{array}{l}\text { Water } \\
\text { Quality }\end{array}$ & EPA & $\begin{array}{l}\text { Contingent } \\
\text { B1dding }\end{array}$ & $\begin{array}{l}\text { Personal } \\
\text { Interview }\end{array}$ & Residents & 202 & 1976 & $\begin{array}{l}\text { S. Platte } \\
\text { River Basin }\end{array}$ & $\begin{array}{l}\text { Use: } \$ 16 \text { to } 74 \text { phpa } \\
\text { Existence: } 6 \text { to } 26 \\
\text { Bequest: } 5 \text { to } 18 \\
\text { Optłon: } \quad 6 \text { to } 34\end{array}$ \\
\hline 7. Oster (1977) & $\begin{array}{l}\text { Water } \\
\text { Quality }\end{array}$ & -- & $\begin{array}{l}\text { Cont fngent } \\
\text { Bidding }\end{array}$ & $\begin{array}{l}\text { Telephane } \\
\text { Interview }\end{array}$ & Residents & 202 & 1973 & $\begin{array}{l}\text { Merrimack } \\
\text { River }\end{array}$ & $\$ 38.64$ phpa \\
\hline $\begin{array}{l}\text { 8. Adams } \\
\text { et al. (1980) }\end{array}$ & $\begin{array}{l}\text { Visual } \\
\text { Aesthet ics }\end{array}$ & NRC & $\begin{array}{l}\text { Contingent } \\
\text { Bidding }\end{array}$ & $\begin{array}{l}\text { Personal } \\
\text { Interview }\end{array}$ & Residents & 786 & 1979 & Varied & $\$ 0.00$ to $10 \mathrm{phprn}$ \\
\hline $\begin{array}{l}\text { 9. Brookshire } \\
\text { et al. (1976) }\end{array}$ & $\begin{array}{l}\text { Visua' } \\
\text { Aesthetics }\end{array}$ & NSF & $\begin{array}{l}\text { Contingent } \\
\text { Bidding }\end{array}$ & $\begin{array}{l}\text { Personal } \\
\text { Interview }\end{array}$ & Users & 82 & 1975 & Lake Powell & $\$ 0.87$ to $\$ 3.11 \mathrm{phpd}$ \\
\hline $\begin{array}{l}\text { 10. Brookshire } \\
\text { et al. (1982) }\end{array}$ & $\begin{array}{l}\text { Air } \\
\text { Quality }\end{array}$ & EPA & $\begin{array}{l}\text { Contingent } \\
\text { gidding }\end{array}$ & $\begin{array}{l}\text { Personal } \\
\text { Interview }\end{array}$ & Residents & 290 & 1978 & Los Angeles & $\$ 5.55$ to 28.18 phpm \\
\hline
\end{tabular}


(Table 4-1, continued)

\begin{tabular}{|c|c|c|c|c|c|c|c|c|c|}
\hline Author and Date & Topic & Sponsar* & $\begin{array}{l}\text { Value } \\
\text { Method }\end{array}$ & $\begin{array}{c}\text { Collection } \\
\text { Method }\end{array}$ & Subjects & Sample & Base Year & Site & Value ${ }^{\star \star}$ \\
\hline \multirow[t]{2}{*}{$\begin{array}{l}\text { 11. Charles River } \\
\text { (1981) }\end{array}$} & $\begin{array}{l}\text { Visual } \\
\text { Aesthetics }\end{array}$ & EPRI & $\begin{array}{l}\text { Contingent } \\
\text { Biddting }\end{array}$ & $\begin{array}{l}\text { Personal } \\
\text { Interview }\end{array}$ & Users & 205 & 1981 & Mesa Verae & $\$ 4.17 \mathrm{pr}$ \\
\hline & & & $\begin{array}{l}\text { Contingent } \\
\text { Bidding }\end{array}$ & $\begin{array}{l}\text { Personal } \\
\text { Interview }\end{array}$ & Users & 205 & 1981 & Mesa Verde & $\$ 0.75$ to $1.10 \mathrm{pv}$ \\
\hline $\begin{array}{l}\text { 12. Cropper } \\
\text { et a1. (1979) }\end{array}$ & $\begin{array}{l}\text { Air } \\
\text { Quality }\end{array}$ & EPA & $\begin{array}{l}\text { Hedonic-- } \\
\text { Magge }\end{array}$ & Census, BLS & SMSA'S & 28 & 1970 & Varied & $\$ 2.50$ to 64.4 pa \\
\hline $\begin{array}{l}\text { 13. Harrison \& } \\
\text { Rubinfeld } \\
\text { (1978) }\end{array}$ & $\begin{array}{l}\text { Air } \\
\text { Quality } \\
\text { (NOX) }\end{array}$ & $\cdots$ & $\begin{array}{l}\text { Hedonic-- } \\
\text { Property }\end{array}$ & 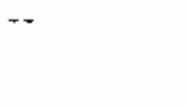 & -- & -- & 1970 & Boston & $\$ 1613$ \\
\hline \multirow[t]{3}{*}{ (1981) } & \multirow[t]{3}{*}{$\begin{array}{l}\text { Air } \\
\text { Quality }\end{array}$} & \multirow[t]{3}{*}{ EPA } & \multicolumn{2}{|l|}{$\begin{array}{l}\text { Direct-Market } \\
\text { (Expenditure } \\
\text { Substitution) }\end{array}$} & SMSA'S & 24 & $1972-73$ & Varied & 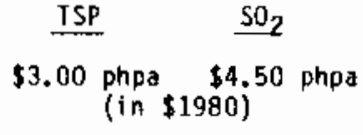 \\
\hline & & & $\begin{array}{l}\text { Hedonic-- } \\
\text { Property }\end{array}$ & $\begin{array}{l}\text { Prior } \\
\text { Est1mates }\end{array}$ & SMSA's & 24 & $\begin{array}{l}1960 \mathrm{~s} \\
1970 \mathrm{~s}\end{array}$ & Varied & $\begin{array}{cc}\$ 260 \text { to } 626 \quad \$ 136 \text { to } \\
\text { phpa } & 194 \\
& \text { phpa } \\
& \text { (in } \$ 1980)\end{array}$ \\
\hline & & & $\begin{array}{l}\text { Hedontc-- } \\
\text { Wage }\end{array}$ & $\begin{array}{l}\text { Mail Survey } \\
\text { (Income } \\
\text { Dynam1cs) }\end{array}$ & Earners & $\begin{array}{l}112 \text { to } \\
1395\end{array}$ & $1967-75$ & Varied & $\begin{array}{l}\$ 843 \text { to } 911 \\
\text { phpa } \\
(1 n \$ 1980)\end{array}$ \\
\hline 15. Nelson (1978) & $\begin{array}{l}\text { Air } \\
\text { Quality } \\
\text { (Tsp, } \\
\text { Oxidents) }\end{array}$ & -- & $\begin{array}{l}\text { Medonic-- } \\
\text { Property }\end{array}$ & Census & $\begin{array}{l}\text { Census } \\
\text { Tracts }\end{array}$ & -- & 1970 & $\begin{array}{l}\text { Washington, } \\
\text { D.C. }\end{array}$ & $\begin{array}{l}\frac{\text { TSP }}{\$ 576 \text { to } 593} \frac{0 x i \text { dents }}{\$ 141-152} \\
\text { per o-0u }\end{array}$ \\
\hline 16. Peckham (1970) & $\begin{array}{l}\text { Air } \\
\text { Quality } \\
\text { (TSP, } \\
\left.\mathrm{SO}_{2}\right)\end{array}$ & -- & $\begin{array}{l}\text { Hedonic-- } \\
\text { Property }\end{array}$ & Census & $\begin{array}{l}\text { Census } \\
\text { Tracts }\end{array}$ & -. & 1960 & Philadelphia & $\mathrm{SO}_{2}: \$ 298$ \\
\hline
\end{tabular}


(Table 4-1, continued)

\begin{tabular}{|c|c|c|c|c|c|c|c|c|c|c|}
\hline & Author and Date & Topic & Sponsor* & $\begin{array}{l}\text { Value } \\
\text { Method }\end{array}$ & $\begin{array}{l}\text { Collection } \\
\text { Method }\end{array}$ & Subjects & Sample & Base Year & Site & Value ${ }^{* \star}$ \\
\hline & 17. Rae (1982) & $\begin{array}{l}\text { Visual } \\
\text { Aesthetics }\end{array}$ & EPRI & $\begin{array}{l}\text { Contingent } \\
\text { Bidding }\end{array}$ & $\begin{array}{l}\text { Personat } \\
\text { Interview }\end{array}$ & Users & 190 & 1981 & $\begin{array}{l}\text { Great Smokey } \\
\text { Natlonal Park }\end{array}$ & $\$ 5.96 \mathrm{pv}$ \\
\hline & & & & $\begin{array}{l}\text { Contingent } \\
\text { Bidding }\end{array}$ & $\begin{array}{l}\text { Personal } \\
\text { Interview }\end{array}$ & Users & 190 & 1981 & $\begin{array}{l}\text { Great Smokey } \\
\text { National Park }\end{array}$ & $\$ 3.64$ to $11.22 \mathrm{pv}$ \\
\hline & $\begin{array}{l}\text { 18. Randall } \\
\text { et al. (1974) }\end{array}$ & $\begin{array}{l}\text { Visual } \\
\text { Aesthet1cs }\end{array}$ & - & $\begin{array}{l}\text { Contingent } \\
\text { Bidding }\end{array}$ & $\begin{array}{l}\text { Personal } \\
\text { Interview }\end{array}$ & $\begin{array}{l}\text { Residents } \\
\text { U Users }\end{array}$ & 526 & 1972 & Four Corners & $\$ 50$ to 85 pa \\
\hline & $\begin{array}{l}\text { 19. Ridker \& } \\
\text { Henning (1967) }\end{array}$ & $\begin{array}{l}\text { Air } \\
\text { Ouality } \\
\left(\mathrm{SO}_{2}\right)\end{array}$ & -- & $\begin{array}{l}\text { Hedontc-- } \\
\text { Property }\end{array}$ & Census & $\begin{array}{l}\text { Census } \\
\text { Tracts }\end{array}$ & -- & 1960 & St. Louis & $\begin{array}{l}\$ 186.50 \\
\text { to } 245 \text { per o-ou }\end{array}$ \\
\hline & $\begin{array}{l}\text { 20. Rowe } \\
\text { et al. (1980) }\end{array}$ & $\begin{array}{l}\text { Visual } \\
\text { Aesthetics }\end{array}$ & EPR I & $\begin{array}{l}\text { Contingent } \\
\text { Bidding }\end{array}$ & $\begin{array}{l}\text { Personal } \\
\text { Interview }\end{array}$ & $\begin{array}{l}\text { Residents } \\
\& \text { Users }\end{array}$ & $\begin{array}{l}26 \text { to } \\
93\end{array}$ & 1976 & Four Corners & $\begin{array}{l}\text { Residents: } \$ 57 \\
\text { to } 82.2 \mathrm{pa} \\
\text { Users: } \$ 2.44 \text { pd }\end{array}$ \\
\hline w & $\begin{array}{l}\text { 21. Schulze } \\
\text { et al. (1980) }\end{array}$ & $\begin{array}{l}\text { Visual } \\
\text { Aesthetics }\end{array}$ & -- & $\begin{array}{l}\text { Cont. ingent } \\
\text { Bidding }\end{array}$ & $\begin{array}{l}\text { Personal } \\
\text { Interview }\end{array}$ & -- & 600 & -- & $\begin{array}{l}\text { 5. W. Mation- } \\
\text { a Parklands }\end{array}$ & $\begin{array}{l}\text { Grand Canyon: } \$ 3.72 \\
\text { to } 9.00 \mathrm{phpm} \\
\text { Region: } \$ 6.61 \text { to } \\
16.10 \mathrm{phpm}\end{array}$ \\
\hline & 22. Smith (1978) & $\begin{array}{l}\text { Air } \\
\text { Qual1 ty } \\
\text { (TSP) }\end{array}$ & -- & $\begin{array}{l}\text { Hedonic-- } \\
\text { Property }\end{array}$ & $\begin{array}{l}\text { New House } \\
\text { Sales }\end{array}$ & Units & -- & 1971 & Chicago & $\$ 430$ to 510 per o-ou \\
\hline & 23. Thayer (1981) & $\begin{array}{l}\text { Visual } \\
\text { Aesthetics }\end{array}$ & NSF & $\begin{array}{l}\text { Cont ingent } \\
\text { Bidding }\end{array}$ & $\begin{array}{l}\text { Personal } \\
\text { Interview }\end{array}$ & Users & 106 & $1976-77$ & $\begin{array}{l}\text { Jemez } \\
\text { Mountains }\end{array}$ & $\$ 2.54 \mathrm{phpv}$ \\
\hline & & & & $\begin{array}{l}\text { Cont ingent } \\
\text { Ad justment }\end{array}$ & $\begin{array}{l}\text { Personal } \\
\text { Interview }\end{array}$ & Users & 106 & $1976-77$ & $\begin{array}{l}\text { Jemez } \\
\text { Mountains }\end{array}$ & $\$ 1.48$ to $7.40 \mathrm{phpv}$ \\
\hline & $\begin{array}{l}\text { 24. Banford } \\
\text { et al. (1977) }\end{array}$ & $\begin{array}{l}\text { Fishing } \\
\text { Pier }\end{array}$ & - & $\begin{array}{l}\text { Cont ingent } \\
\text { Bidding }\end{array}$ & $\begin{array}{l}\text { Personal } \\
\text { Interview }\end{array}$ & Residents & 80 & $\cdots$ & $\begin{array}{l}\text { hite Rock, } \\
\text { B.C. }\end{array}$ & $\begin{array}{ll}\text { WTP: } & \$ 43 \mathrm{pa} \\
\text { WTA: } & \$ 120 \mathrm{pa}\end{array}$ \\
\hline & $\begin{array}{l}\text { 25. Brookshire } \\
\text { et al. } \\
(1977,1980)\end{array}$ & $\begin{array}{l}\text { Wildlife } \\
\text { (ELK } \\
\text { contacts) }\end{array}$ & -- & $\begin{array}{l}\text { Contingent } \\
\text { Bidding }\end{array}$ & -- & $\begin{array}{l}\text { Munters, } \\
\text { Fishers }\end{array}$ & -- & -- & $\begin{array}{l}\text { Laramie, } \\
\text { Wyoming }\end{array}$ & $\begin{array}{ll}\text { WTP: } & \$ 54.00 \\
\text { WTA: } & \$ 142.00\end{array}$ \\
\hline
\end{tabular}


(Table 4-1, continued)

\begin{tabular}{|c|c|c|c|c|c|c|c|c|c|}
\hline Author and Date & Topic & Sponsor* & $\begin{array}{l}\text { Yalue } \\
\text { Method }\end{array}$ & $\begin{array}{l}\text { Collection } \\
\text { Method } \\
\end{array}$ & Subjects & Sample & Base Year & Site & Value ${ }^{\star \star}$ \\
\hline $\begin{array}{l}\text { 26. Brown } \\
\text { et al. (1978) }\end{array}$ & $\begin{array}{l}\text { Hunting } \\
\text { Fishing }\end{array}$ & $\mathrm{F} \& \mathrm{H}$ & Hedonic & $\begin{array}{l}\text { Mai } 1 \\
\text { Survey }\end{array}$ & Hunters & $154-1220$ & 1975 & National 1 & $\begin{array}{l}\text { Hunting } \\
\text { Deer: } \$ 34 \text { to } 86 \text { pd } \\
\text { Elk, antelope, wild } \\
\text { turkey, other: } 39 \\
\text { to } 94 \text {. } \\
\text { Upland Btrds: } 7 \text { to } 32 \\
\text { Rabbits, squirrels, } \\
\text { others: } 5 \text { to } 24 \\
\text { Waterf owl: } 9 \text { to } 29 \\
\text { Doves, Hoodcock } \\
\text { others: } 3 \text { to } 14\end{array}$ \\
\hline & & & & & & & & & $\begin{array}{l}\text { Freshwater Fishing } \\
\text { Trout, Tandlocked } \\
\text { salmon: } \$ 11 \text { to } 43 \\
\text { Salmon, steelhead: } \\
38 \text { to } 63 \\
\text { Bass, musk te, pike, } \\
\text { walleye: } 16 \text { to } 39 \\
\text { Pantioh, catfish, } \\
\text { other: } 12 \text { to } 38\end{array}$ \\
\hline & & & & & & & & & Saltwater: $\begin{array}{r}16 \text { to } \\
45 \mathrm{pd}\end{array}$ \\
\hline
\end{tabular}

\begin{tabular}{|c|c|c|c|c|c|c|c|c|c|c|}
\hline & $\begin{array}{l}\text { Brown } \\
\text { et al. (1972) }\end{array}$ & $\begin{array}{l}\text { Saltwater } \\
\text { Salmon, } \\
\text { Fishing }\end{array}$ & -- & -- & $\cdots$ & - & -- & 1962 & Oregon & $\$ 20 \mathrm{pd}$ \\
\hline 28. & $\begin{array}{l}\text { Cicchetti } \\
\text { et al. (1976) }\end{array}$ & Skłing & -- & $\begin{array}{l}\text { Iravel } \\
\text { Cost }\end{array}$ & $\begin{array}{l}\text { Persona } \\
\text { Interview }\end{array}$ & Skiers & 330 & 1969 & Mineral King & $\$ 35.2$ to $\$ 140.00$ pupa \\
\hline 29. & $\begin{array}{l}\text { Cicchetti \& } \\
\text { Smtth (1973) }\end{array}$ & $\begin{array}{l}\text { Recreation } \\
\text { \& Congestion }\end{array}$ & -- & -- & -- & -- & - & -- & $\begin{array}{l}\text { Spantsh Peaks } \\
\text { Primittve } \\
\text { Area }\end{array}$ & -- \\
\hline 30. & $\begin{array}{l}\text { Daubert \& } \\
\text { Young (1981) }\end{array}$ & $\begin{array}{l}\text { Recreation } \\
\& \text { Instream } \\
\text { Flow }\end{array}$ & -- & $\begin{array}{l}\text { Contingent } \\
\text { Bidding }\end{array}$ & $\begin{array}{l}\text { Personal } \\
\text { Interview }\end{array}$ & Users & 134 & 1978 & Poudre River & $\$ 4.85$ to $\$ 30.35$ pupd \\
\hline 31. & $\begin{array}{l}\text { Deyak \& } \\
\text { Smith } \\
(1978)\end{array}$ & $\begin{array}{l}\text { Recreation } \\
\text { \& Congestion }\end{array}$ & $\cdots$ & -- & -- & Users & -- & 1972 & -- & - \\
\hline
\end{tabular}


(Table 4-7, continued)

\begin{tabular}{|c|c|c|c|c|c|c|c|c|c|c|}
\hline Author and Uate & Topic & Spansor* & $\begin{array}{l}\text { Value } \\
\text { Method }\end{array}$ & $\begin{array}{l}\text { Collection } \\
\text { Method } \\
\end{array}$ & Subjects & Sample & Base Year & Site...... & & Value \\
\hline \multirow[t]{2}{*}{ 32. Fisher (1982) } & Deer Hunting & -- & $\begin{array}{l}\text { Contingent } \\
\text { Bidding }\end{array}$ & $\begin{array}{l}\text { Mail } \\
\text { Survey }\end{array}$ & Hunters & 208 & 1972 & -- & $\begin{array}{l}\text { WTP: } \\
\text { WTA: } \\
\text { C.S.: }\end{array}$ & $\begin{array}{c}\$ 4.33 \mathrm{phpd} \\
\$ 159.00 \\
\$ 80.00\end{array}$ \\
\hline & & & $\begin{array}{l}\text { Travel } \\
\text { Cost }\end{array}$ & $\begin{array}{l}\text { Ma†l } \\
\text { Survey }\end{array}$ & Hunters & $20 \mathrm{~B}$ & -- & -- & & -- \\
\hline $\begin{array}{l}\text { 33. Gordon \& } \\
\text { Knetsch (1979) }\end{array}$ & $\begin{array}{l}\text { Availability } \\
\text { of Freshwater } \\
\text { Fishing Site }\end{array}$ & -- & $\begin{array}{l}\text { Contingent } \\
\text { Valuation }\end{array}$ & $\begin{array}{l}\text { Mail, } \\
\text { Telephone } \\
\text { Survey }\end{array}$ & Anglers & 785 & - & $\begin{array}{l}\text { British } \\
\text { Columbia }\end{array}$ & & -- \\
\hline $\begin{array}{l}\text { 34. Hanmack \& } \\
\text { Brom (1974) }\end{array}$ & $\begin{array}{l}\text { Wetland \& } \\
\text { Waterfowl } \\
\text { Resources }\end{array}$ & $\ldots$ & $\begin{array}{l}\text { Contingent } \\
\text { Valuation }\end{array}$ & $\begin{array}{l}\text { Mail } \\
\text { Survey }\end{array}$ & Hunters & - & -. & -- & $\begin{array}{l}\text { WTP: } \\
\text { WTA: }\end{array}$ & $\begin{array}{l}\$ 241 \\
\$ 1044\end{array}$ \\
\hline $\begin{array}{l}\text { 35. Hathews \& } \\
\text { Brown }(1970)\end{array}$ & $\begin{array}{l}\text { Salmon } \\
\text { Sport } \\
\text { Fìs șing }\end{array}$ & -- & - & $\cdots$ & - & -- & 1967 & Washington & $\$ 27$ to & $063 \mathrm{pd}$ \\
\hline $\begin{array}{l}\text { 36. McConnel 1 } \\
(1977)\end{array}$ & $\begin{array}{l}\text { Recreation } \\
\text { \& Congestion } \\
\text { (Beach) }\end{array}$ & NOAO & Cont ingent & $\begin{array}{l}\text { Personal } \\
\text { Interview }\end{array}$ & Users & 229 & 1974 & Rhode Istand & $\$ 1.86$ & pupd \\
\hline $\begin{array}{l}\text { 37. Menz \& } \\
\text { Mullen (1981) }\end{array}$ & $\begin{array}{l}\text { Recreation } \\
\& \text { Congestion }\end{array}$ & -- & $\begin{array}{l}\text { Travel } \\
\text { Cost }\end{array}$ & $\begin{array}{l}\text { Mail } \\
\text { Survey }\end{array}$ & Users & 402 & $1974-75$ & $\begin{array}{l}\text { Adi rondack } \\
\text { Migh Peaks }\end{array}$ & & -- \\
\hline 38. Meyer (1980) & $\begin{array}{l}\text { Fish \& } \\
\text { Hildife }\end{array}$ & FEW & $\begin{array}{l}\text { Contingent } \\
\text { valuation }\end{array}$ & $\begin{array}{l}\text { Personal } \\
\text { interview }\end{array}$ & Residents & 1528 & $1979-80$ & $\begin{array}{l}\text { California's } \\
\text { Central } \\
\text { Valley }\end{array}$ & $\begin{array}{l}\text { Songbi } \\
\text { Water } \\
62 \mathrm{t} \\
\text { Migrat. } \\
91 \mathrm{t} \\
\text { Animal } \\
\text { Cove }\end{array}$ & $\begin{array}{l}\text { irds: } \$ 67 \text { to } 353 \\
\text { phpa } \\
\text { \& Shore Birds: } \\
\text { to } 429 \\
\text { ting Fish: } \\
\text { to } 361 \\
\text { 1s using natural } \\
\text { er: } 91 \text { to } 445\end{array}$ \\
\hline
\end{tabular}


(Table 4-1, continued)

\begin{tabular}{|c|c|c|c|c|c|c|c|c|c|}
\hline Author and Date & Topis.... & Sponsor* & $\begin{array}{l}\text { Value } \\
\text { Method }\end{array}$ & $\begin{array}{l}\text { Collect ton } \\
\text { Method }\end{array}$ & Subjects & Sample & Basse Year & St. stte & Value \\
\hline 39. Meyer (1979) & $\begin{array}{l}\text { Fish \& } \\
\text { Wildife }\end{array}$ & F 84 & $\begin{array}{l}\text { Contingent } \\
\text { Valuation }\end{array}$ & -- & -- & & 1975 & $\begin{array}{l}\text { San Francisco } \\
\text { Bay Area }\end{array}$ & $\begin{array}{l}\text { River Salmon \& } \\
\text { Steelhead fishing: } \\
\$ 51 \\
\text { Al other fishing: } \\
\$ 22 \\
\text { Hunting waterfow1: } \\
\$ 33 \\
\text { Hunt ing migratory birds: } \\
\$ 39\end{array}$ \\
\hline 40. Meyer (1976) & $\begin{array}{l}\text { Sport } \\
\text { Fishing }\end{array}$ & 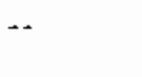 & $\cdots$ & -- & -- & & 1975 & $\begin{array}{l}\text { S. British } \\
\text { Columbia }\end{array}$ & $\$ 16$ to $27 \mathrm{pd}$ \\
\hline $\begin{array}{l}\text { 41. Randall } \\
\text { Brookshire } \\
\text { (197B) }\end{array}$ & Elk Hunting & -- & -- & $\begin{array}{l}\text { Personal } \\
\text { Interview }\end{array}$ & -- & & -- & -- & $\$ 30$ to $64 \mathrm{pd}$ \\
\hline 42. Sinclair $\begin{array}{l}\text { Sing) } \\
(1976)\end{array}$ & $\begin{array}{l}\text { Avallability } \\
\text { of Freshwater } \\
\text { Fishing Stte }\end{array}$ & - & $\begin{array}{l}\text { Cont ingent } \\
\text { valuation }\end{array}$ & $\begin{array}{l}\text { Ma1l, } \\
\text { Telephone } \\
\text { Survey }\end{array}$ & Anglers & 785 & -- & Brittsh & $\begin{array}{ll}\text { WTP: } & \$ 35 \\
\text { WTA: } & \$ 700\end{array}$ \\
\hline $\begin{array}{l}\text { 43. Sinden \& } \\
\text { Wyckoff } \\
(1976)\end{array}$ & Recreation & $\mathrm{DOt}$ & $\begin{array}{l}\text { Indiffer- } \\
\text { ence } \\
\text { Mapplng }\end{array}$ & $\begin{array}{l}\text { Personal } \\
\text { Interview }\end{array}$ & $\begin{array}{l}\text { Recreatton - } \\
\text { lsts }\end{array}$ & $\begin{array}{l}189 \\
(5)\end{array}$ & 1972 & $\begin{array}{l}\text { South San- } \\
\text { tiam Valley, } \\
\text { Oregon }\end{array}$ & WTP: $\$ 1.5$ to 9.3 \\
\hline \multirow[t]{3}{*}{ 14. Nero (1982) } & $\begin{array}{l}\text { 0zone } \\
\text { Depletion }\end{array}$ & BPA & $\begin{array}{l}\text { Contingent } \\
\text { valuation }\end{array}$ & $\begin{array}{l}\text { Personal } \\
\text { Interview }\end{array}$ & $\begin{array}{l}\text { College } \\
\text { Students }\end{array}$ & 139 & -- & $\begin{array}{l}\text { Wyoming, } \\
\text { Colorado }\end{array}$ & $\$ 00.00$ to 237.40 \\
\hline & \multirow{2}{*}{\multicolumn{2}{|c|}{$\begin{array}{l}\text { Municipal } \\
\text { Infrastructure }\end{array}$}} & $\begin{array}{l}\text { Contingent } \\
\text { Valuation }\end{array}$ & $\begin{array}{l}\text { Personal } \\
\text { Interview }\end{array}$ & Residents & 278 & -- & New Mexico & \\
\hline & & & Hedonic & $\begin{array}{l}\text { Published } \\
\text { Data }\end{array}$ & Town & 26 & $1970-75$ & New Mexico & $\$ 29$ pe \\
\hline $\begin{array}{l}\text { 45. Bajgier \& } \\
\text { Moskowitz } \\
(1978)\end{array}$ & $\begin{array}{l}\text { Drinking } \\
\text { Water } \\
\text { Quality }\end{array}$ & OWRT & $\begin{array}{l}\text { Contingent } \\
\text { Bidding }\end{array}$ & $\begin{array}{l}\text { Mail } \\
\text { Survey }\end{array}$ & Students & 39 & -- & $\begin{array}{l}\text { Purdue } \\
\text { University }\end{array}$ & $\$ 0.36$ to 4.32 phpa \\
\hline
\end{tabular}


(Table 4-1, continued)

Note: Data in this table should only be employed after consulting the source for caveats.

* Sponsors are defined as:

EPA Environmental Protection Agency

NRC Nuclear Regulatory Commission

NSF National Science Foundation

EPRI Electric Power Research Institute

F\&W U.S. Fish and Wildlife Service

NOAO National Oceanic and Atmospheric Office

DOI Department of intertor

BPA Bonneville Power Admintstration

$\star *$ Values are defłned as:

pd is per day

pe is per earner

phpa is per household per year

phpa is per household per year

pepa is per capita per year

phom is per household per manth

pv is per vehicle

pa is per year

o-ou is per awner-occupied unit

pupa is per user per year

UTP is willingness-to-pay

WTA is willingness-to-accept-compensation

CS is consumer stirplus 


\subsection{References}

1. H. S. Gordon, "The Economic Theory of Common Property Resource: Fisheries," Journal of Political Economy 62(2), 124-42 (1954). Available in public and technical libraries.

2. F. W. Bell and E. R. Canterbery, Benefits from Water Pollution Abatement: Coastal Waters, 2 volumes. Report to the National Commission on water Quality, April 1976. Available for purchase from the National Technical Information Service, Springfield, Virginia 22161.

3. J. A. Crutchfield and G. Pontecaruo, The Pacific Salmon Fisheries: A Study of Rational Conservation, Johns Hopkins Press, Baltimore, Maryland, 1969 .

4. M. Clawson, Methods of Measuring the Demand for and the Value of Outdoor Recreation, Reprint No. 10, Washington, D.C. Resources for the Future, 1959. Available from Resources for the Future, Washington, D.C.

5. J. L. Knetsch, "Outdoor Recreation Demands and Benefits," Land Economics 39(4), 387-396 (1963). Available in public and technical Tibraries.

6. M. Clawson and J. L. Knetsch, Economics of Outdoor Recreation, Johns Hopkins Press, Baltimore, Maryland, 1966.

7. G. Becker, "A Theory in the Allocation of Time," Economic Journal 75(299), 493-517 (1965). Available in public and technical libraries.

8. K. Lancaster, "A New Approach to Consumer Theory," Journal of Political Economy 74(2), 132-157 (1966). Available in public and technical Tibraries.

9. D. M. Brown, "The Demand for National Park Service Output." Paper presented at the Southern Economic Association Meetings, 1977. Available from the Economics Department, Georgetown University, Washington, D.C. 20057 .

10. C. J. Cicchetti, A. C. Fisher, and V. K. Smith, "An Econometric Evaluation of a Generalized Consumer Surplus Measure: The Mineral King Controversy," Econometrica 44(6), 1259-1276 (1976). Available in public and technical Tibraries.

11. T. A. Deyak and V. K. Smith, "Congestion and Participation in Outdoor Recreation: A Household Production Function Approach," Journal of Environmental Economics and Management 5(1), 63-84 (1976). Available in public and technical libraries. 
12. K. McConnel1, "Some Problems in Estimating the Demand for Outdoor Recreation: Reply," American Journal of Agricultural Economics 58(3), 598-599 (1976). Available in public and technical libraries.

13. K. McConnell and I. Strand, "Measuring the Cost of Time in Recreation Demand Analysis: An Application to Sport Fishing," American Journal of Agricultural Economics 63(1), 153-156 (1981). Available in public and technical libraries.

14. R. W. Vickerman, "The Evaluation of Benefits from Recreation Projects," Urban Studies 11, 277-288 (1974). Available in public and technical Tibraries.

15. A. M. Freeman III, The Benefits of Environmental Improvenent, Johns Hopkins University Press, Baltimore, Maryland, 1979.

16. D. R. Burt and D. Brewer, "Estimation of Net Social Benefits from Dutdoor Recreation," Econometrica 39(5), 813-827 (1971).

17. F. 3. Cesario, "Value of Time in Recreation Benefit Studies," Land Economics 55(1), 32-41 (1976). Available in public and technical Tibraries.

18. F. J. Cesario and J. L. Knetsch, "A Recreation Site Demand and Benefit Estimation Model," Regional Studies 10,97-104 (1976). Available in public and technical libraries.

19. K. E. McConnell and V. A. Duff, "Estimating Net Benefits of Outdoor Recreation Under Conditions of Excess Demand," Journal of Environmental Economics and Management 2, 224-230 (1976). Available in public and technical libraries.

20. A. M. Freeman III and R. A. Haveman, "Congestion, Quality Deterioration and Heterogeneous Tastes," Journal of Public Economics 8(2), 225-232 (1977). Available in public and technical libraries.

21. A. Fisher and J. Krutilla, "Valuing Long-Run Ecological Consequences and Irreversibilities," in Cost-Benefit Analysis and Water Pollution Policy, Henry Peskin and Eugene Seskin, eds. (The Urban Institute, Washington, D.C., 1975), PP. 271-290.

22. C. J. Cicchetti and K. V. Smith, "Congestion, Quality Deterioration, and Optimal Use: Wilderness Recreation in the Spanish Peaks Primitive Area," Social Science Research 2(1), 15-30 (1973). Available in public and technicat Tibraries.

23. K. E. McConnell, "Congestion and Willingness to Pay: A Study of Beach Use," Land Economics 53(2), 185-195 (1977). Available in public and technical libraries. 
24. P. G. Al len, T. H. Stevens, and S. A. Barrett, "The Effect of Variable Omission in the Travel Cost Technique," Land Economics 57(2), 173-186 (1981). Available in public and technical libraries.

25. W. G. Brown and F. Nawas, "Impact of Aggregation on the Estimation of Outdoor Recreation Demand Functions," American Journal of Agricultural Economics 55(2), 246-249 (1973). Avaitable in public and technical Tibraries.

26. R. L. Gum and W. E. Martin, "Problems and Solutions in Estimating the Demand for and Value of Rural Dutdoor Recreation, "American Journal of Agricultural Economics 57(4), 558-566 (1975). Avaitable in public and technical libraries.

27. R. B. Ridker and J. A. Henning, "The Determinants of Residential Property Values with Special Reference to Air Pollution," Review of Economics and Statistics 49, 246-257 (1967). Available in public and technical Tibraries.

28. A. M. Freeman III, "Hedonic Prices, Property Values and Measuring Environmental Benefits: A Survey of the Issues," Scandinavian Journal of Economics 81(2), 154-173 (1979). Available in pubTic and technicat Tibraries.

29. L. M. Court, "Entrepreneurial and Consumer Demand Theories for Commodity Spectra," Econometrica 9(1), 135-162 and 9(2), 241-287 (1941). Available in public and technical libraries.

30. F. J. Cronin, "The Efficiency of Housing Search," Southern Economic Journal 48(4), 1016-1030 (1982). Available in public and technical Tibraries.

31. F. J. Cronin, "Estimation of Dynamic Expenditure Functions for Housing," Review of Economics and Statistics 64(1), 97-103 (1982). Available in public and technical libraries.

32. S. Rosen, "Hedonic Prices and Implicit Markets: Product Differentiation in Pure Competition," Journal of Political Economy 82(1), 34-55 (1974). Available in public and technical libraries.

33. D. Harrison Jr. and D. L. Rubinfeld, "Hedonic Housing Prices and the Demand for Clean Air," Journal of Environmental Economics and Management 5, 81-102 (1978). Avaitable in public and technical libraries.

34. A. M. Freeman III, Benefits of Air and Water Pollution Control: A Review and Synthesis of Recent Estimates. Prepared for the Council on Environmental Quality, Washington, D.C., December 1979.

35. K. G. Maler, Property Values and Damage Functions, pp. 2-6, Electric Power Research Institute, Palo Alto, California, 1977. 
36. A. Randall, "Evaluating Non-Market Goods and Services: Some Conceptual Considerations." Presented to the Symposium on Evaluation of Non-Market Goods at the annual meeting of the American Agricultural Economics Association, San Diego, California, July 31-August 3, 1977, p. 19. Staff Paper 51 available from the Department of Agricultural Economics, University of Kentucky, Lexington, Kentucky.

37. J. A. Hebert, R. Shikiar, and R. W. Perry, Valuing the Environment Via Bidding Games: A Psychological Perspective, PNL-2950, Pacific Northwest Laboratory, Richland, Washington, 1980. Available from Pacific Northwest Laboratory, Richland, Washingt on 99352.

38. R. C. Bishop and T. A. Heberlein, "Measuring Values of Extra-market Goods: Are Indirect Measures Biased?" American Journal of Agricultural Economics 61(5), 926-930 (1979). Available in public and technical Tibraries.

39. M. A. Thayer, "Contingent Valuation Techniques for Assessing Environmental Impacts: Further Impacts," Journal of Environmental Economics and Management, 27-44 (1981). Available in public and technicat libraries.

40. D. A. Greenley, R. G. Walsh, and R. A. Young, "Option Value: Empirical Evidence from a Case Study of Recreation and Water Quality," The Quarterly Journal of Economics 96(4), 657-673 (1981). Available in public and technical Tibraries.

41. R. Rowe and F. Blank, "Oeviations in Empirical Consumer's Surplus Measures," Paper presented for the Fifty-Sixth Annual Conference of the Western Economics Association, July 2-6, 1981, San Francisco, California.

42. W. D. Schulze, R. d'Arge, and D. S. Brookshire, "Valuing Environmental Commodities: Some Recent Experiments," Land Economics 57(2), 151-172 (1981). Available in public and technical libraries.

43. P. Bohm, "Estimating Demand for Public Goods: An Experiment," European Economic Review 3(2), 110-130 (1972). Available in public and technical Tibraries.

44. R. Rowe, R. d'Arge, and D. Brookshire, "An Experiment in the Economic Value of Visibility," Journal of Environmental Economics and Management 7, 1-19 (1980). Available in public and technical libraries.

45. D. B. Brookshire, B. Ives, and W. D. Schulze, "The Valuation of Aesthetic Preferences," Journal of Environmental Economics and Management 3, 325346 (1976). Available in public and technical libraries. 
46. F. J. Cronin, Valuing Nonmarket Goods Through Contingent Markets, PNL4255, Pacific Northwest Laboratory, Richland, Washington, 1982. Available from Pacific Northwest Laboratory, Richland, Washington 99352.

47. P. Bohm, "Estimating Willingness to Pay: Why and How?" Scandinavian Journal of Economics 81(2), 142-153 (1979). Available in public and technical libraries.

48. D. S. Brookshire, R. C. d'Arge, W. D. Schulze, and M. Thayer, "Experiments in Valuing Public Goods," in Advances in Applied Microeconomics, V. Kerry Smith, ed., (New York, JAI Press, Inc., 1983).

49. J. T. Daubert and R. A. Young, "Recreational Demands for Maintaining Instream Flows: A Contingent Valuation Approach," American Journal of Agricultural Economics 63(4), 666-676 (1981). Avaitable in public and technical libraries.

50. A. Randal1, B. Ives and C. Eastman, "Bidding Games for the Valuation of Aesthetic Environmental Improvements," Journal of Environmental Economics and Management 1, 132-149 (1974). Available in public and technical libraries.

51. D. S. Brookshire et al., "Valuing Public Goods: A Comparison of Survey and Hedonic Techniques," American Economic Review 72(1), 1965-1977 (1982). Available in public and technical libraries.

52. E. J. Mishan, Cost-Benefit Analysis, pp. 177-178, Praeger Publishers, New York, 1971 .

53. R. C. Adams et a1., The Visual Aesthetic Impact of Alternative Closed Cycle Cooling Systems, Vol. I i Research Design, Estimation, and Prediction, PNL-2952, Pacific Northwest Laboratory, Richland, Washington. Available from Pacific Northwest Laboratory, Richland, Washington 99352 .

54. I. Hardie and I. Strand, "Measurement of Economic Benefits for Potential Public Goods," American Journal of Agricultural Economics 61(2), 313-317 (1979). Available in public and technical Tibraries.

55. J. A. Sinden and J. B. Wyckoff, "Indifference Mapping: an Empirical Methodology for Economic Evaluation of the Environment," Regional Science and Urban Economics 6(1), 81-103 (1976). Available in pubic and technical libraries.

56. P. A. Findlater and J. A. Sinden, "Estimation of Recreation Benefits from Measured Utility Functions," American Journal of Agricultural Economics 64(1), 102-109 (1982). Available in public and technical libraries. 
57. W. H. Desvousages, V. K. Smith, and M. P. McGivney, "A Comparison of Alternative Approaches for Estimating Recreation and Related Benefits of Water Quality Improvements." Draft report prepared by Research Triangle Institute, Research Triangle Park, North Carolina, for the U.S. Environmental Protection Agency. Available from Research Triangle Institute, Research Triangle Park, North Carolina 27709.

58. R. Willig, "Consumer's Surplus Without Apology," American Economic Review 66(4), 589-597 (1976). Available in public and technical libraries.

59. A. Randall and J. Stoll, "Consumer Surplus in Commodity Space," American Economic Review 70(3), 449-455 (1980). Available in public and technical Tibraries. 



\section{CONCLUSIONS AND RECOMMENDATIONS}

In recent years the importance of evaluating federal projects and regulatory policies by means of comprehensive, economically based cost-benefit analyses has been emphasized and recommended. The executive and legislative branches of the federal government, in particular, have stressed the importance of thorough economic analyses for evaluating federal policies. Executive Order 12291 requires that regulatory agencies prepare Regulatory Impact Analyses (RIAs) on all proposed major regulations; these analyses must quantify and evaluate the benefits and costs of regulatory alternatives, and choose the regulation having the least net cost to society. In carrying out this mandate, federal agencies are employing formal cost-benefit analyses which monetize the benefits and costs involved in an action's full range of effects.

In addition to Executive Order 12291, several congressional motions have recently been passed or proposed which emphasize the need for an analytical cost-benefit approach to evaluate proposed regulatory policies. Both versions of the Regulatory Reform Bill would require that NRC comply with these proposed procedures for performing regulatory analysis.

Several federal agencies* have already recognized the crucial role of costbenefit analysis in the planning and decision-making process. These agencies have undertaken major efforts to make cost-benefit analysis a more valuabie tool by increasing its comprehensiveness. That is, the agencies have attempted to assess all beneficial and adverse impacts of proposed actions within the economic cost-benefit framework. Such cost-benefit analyses have incorporated economic (monetary) valuations of environmental and other nonmarket impacts.

In light of recent legislation and the increasing emphasis of valuing nonmarket impacts, the NRC may be required to upgrade analytical techniques for performing regulatory analysis. A variety of studies and research topics are available to the NRC for understanding and applying the valuation techniques and evaluation procedures of cost-benefit analysis. In this regard, the NRC might consider investigating such areas as,

(1) the techniques appropriate for monetizing nonmarket (e.g., environmental and safety) impacts, relevant to NRC actions and policies,

(2) the appropriateness of using existing survey data to analyze nonmarket impacts relevant to NRC actions and policies, and

(3) the appropriateness of using monetized estimates of nonmarket impacts published in secondary sources for NRC cost-benefit analyses.

* Such as, the Environmental Protection Agency, the National Park Service, the Water Resources Council, the Bonneville Power Administration and the U.S. Fish and Wildi ife Service. 
Various economic studies involving the above areas could be undertaken by the NRC to obtain substantive information and to acquire experience in applying valuation techniques for deriving dollar estimates of nonmarket impacts attributable to regulatory actions or policies of the NRC.

Specific methodologies for valuing nonmarket impacts were identified and discussed in detail in Chapter 4 of this paper. Several techniques appropriate for the NRC's need to value environmental and safety consequences include:

(1) travel cost,

(2) contingent behavior (willingness-to-pay/willingness-to-accept compensation),

(3) nedonic price technique, and

(4) direct market value approach.

The travel cost, contingent bidding, and hedonic price techniques can of ten be applied with existing survey data.* The 1980 National Survey of Hunting, Fishing and Wildlife Associated Recreation and the 1982-1983 Nationwide Recreation Survey (available in late 1983) provide useful estimates for various recreational activities with which contingent market valuation studies can be conducted. For example, the NRC could estimate the value of increased recreation (boating, better fishing) associated with the cooling lake at a power plant. By examining the residential property markets in affected areas, the hedonic pricing technique could be used to derive the economic impacts of air and noise pollution attributable to the construction and operation of a nuclear power facility.

As an alternative to deriving monetized estimates of nonmarket impacts from raw data, the NRC could apply a cost-benefit analysis to estimates published in secondary sources. Table 4-1 lists a wide range of location-specific nonmarket impact assessment estimates for a variety of recreational activities, distinct levels of air and water quality, and visual aesthetics. Although some disparity in the techniques and data sets exists across the sources, the estimates do appear reasonable. Each study, however, is subject to certain caveats, and the NRC should be well aware of these before proceeding to use the estimates.

Analytical requirements for evaluating expected economic impacts from a nuclear facility are difficult because many nonmarket impacts (e.g., environmental impacts) are not easily quantified in commensurable units. Consequently, overall cost-benefit estimates of a nuclear facility have been difficult to identify. In order to help resolve this problem, the NRC

\footnotetext{
* See Appendix B for a brief summary of survey data sources. The NRC should become familiar with these surveys for the purpose of determining whether the survey data may be used in conjunction with valuing the costs and benefits of nuclear facilities.
} 
should consider undertaking research in the three areas outlined above. Each area of study would provide the NRC with familiarity and experience in developing and applying economic techniques to value (monetize) nonmarket impacts associated with nuclear facilities. 



\section{BIBLIOGRAPHY}

Anderson, R. J. and N. C. Bonsor. "Al location, Congestion and the Valuation of Resources." Land Economics 50(1), 51-57 (1974). Available in public and technical libraries.

Anderson, R. J. and T. D. Crocker. "Air Pollution and Residential Property Values." Urban Studies 8, 1971-1980 (1971). Available in public and technical Tibraries.

Anderson, R. J. et al. Quantifying the Benefits to the National Economy from Secondary Application of NASA Technology. NASW-2734. Prepared for the National Aeronautics and Space Administration, 1975. Available from Mathematica, Inc., Princeton, New Jersey.

Banford, N. D., J. L. Knetsch and G. A. Mauser. "Compensating and Equivalent Variation Measures of Consumer's Surplus: Further Survey Results." Unpublished paper. 1977. Available from Department of Economics and Commerce, Simon Fraser University, Vancouver, British Columbia.

Ben-David, S., W. D. Schulze, S. Noll and M. Thayer. The Economics of Geothermal Energy: A Case Study. APR 75-18249. Prepared for the National Science Foundation, Washington, D.C., 1977.

Binkley, C. and W. M. Hanemann. The Recreation Benefits of Water Quality Improvement: Analysis of Day Trips in Urban Setting. EPA-600/5-78-010. Washington, D.C.: U.S. Envíronmental Protection Agency, 1978.

Blank, F. et al. "Valuation of Aesthetic Preferences: A Case Study of the Economic Value of Visibility." Research report to the Electric Power Research Institute, Resource and Environmental Economics Laboratory, University of Wyoming, 1977.

Bohm, P. "0ption Demand and Consumer's Surplus: Comment." American Economic Review 65(4),733-736 (1975). Available in public and technical libraries.

Bonneville Power Administration. "Draft Procedure for Estimating Resource Cost Effectiveness." Portland, Oregon: Bonneville Power Administration, March 1982.

Bouwes, N. W. Sr. and R. Schneider. "Procedures to Estimating Benefits of Water Quality Change." American Journal of Agricultural Economics 61(3), 535-539 (1979). Available in public and technical libraries.

Bradford, D. D. and M. Hildebrandt. "Observable Preferences for Public Goods." Journal of Public Economics 8, 106-114 (1977). Available in public and technical libraries. 
Bradford, D. D. "Benefit-Cost Analysis and Demand Curves for Public Goods." Kyklos 23(4), 775-791 (1970). Available in public and technical libraries.

Brookshire, D. S. and T. D. Crocker. "The Advantages of Contingent Valuation Methods for Benefit-Cost Analysis." Public Choice 36(2), 235-252 (1981). Available in public and technical libraries.

Brookshire, D. and R. d'Arge. "Resource Impacted Communities: Economics, Planning and Management." Paper presented at the fourth U.S.-U.S.S.R. Symposium on Comprehensive Analysis of the Environment, Jackson, Wyoming, 1979.

Brookshire, D. et al. Methodological Experiments in Valuing Wildlife Resources: Phase I Interim Report to the United States Fish and Wild ife Service. Prepared for the U.S. Fish and Wildlife Service, Washington, D.C., 1977.

Brookshire, D., A. Randall, and J. Stoll. "Valuing Increments and Decrements in Natural Resource Service Flows." Anerican Journal of Agricultural Economics 62(3), 478-48B (1980).

Brookshire, D. S., R. C. d'Arge, W. D. Schulze, and M. Thayer. Experimental Methods for Valuing Aesthetics and Health Effects in the South Coast Air Basin: An Overview. Resource and Environmental Economics Laboratory, Research Paper 7, May 1979.

Brookshire, D. S., R. d'Arge, W. D. Schulze, and M. Thayer. Methods Development for Assessing Tradeoffs in Environmental Management, Volume II, Experiments in Valuing Non-Market Goods: A Case Study of Alternative Measures of Air Pollution Control in the South Coast Air Basin of Southern California. Prepared for the U.S. Environmental Protection Agency, Washington, D.C., 1979.

Brookshire, D. S., L. S. Eubanks and A. J. Randa11. Option and Existence Values for Wildlife Resources: An Experiment. Resource and Environmental Economics Laboratory, University of Wyoming, Laramie, Wyoming, 1979.

Brown, G. "Pricing Seasonal Recreation Services." Western Economic Journal $9(2), 218-225$ (1971). Available in public and technical Tibraries.

Brown, G., J. J. Charbonneau, and M. J. Hay. "The Value of Wildlife Estimated by the Hedonic Approach." Working Paper No. 6, prepared for the U.S. Fish and Wildife Service, Washington, D.C., 1978.

Brown, G. "Estimating Values of Wildlife: Analysis of the 1975 Hunting and Fishing Survey." Working Paper No. 7, prepared for the U.S. Fish and Wildlife Service, Washington, D.C., 1978. 
Brown, G. and H. 0. Pollakowski. "Economic Valuation of Shoreline." Review of Economics and Statistics 59(3), 272-278 (1977). Available in pubTic and technical Tibraries.

Brown, J. N. and H. S. Rosen. "On the Estimation of Structural Hedonic Price Models." Econometrica 50(3), 765-768 (1982). Available in public and technical Tibraries.

Brown, W. G., A. Singh, and E. Castle. "Net Economic VaTue of the Oregon Salmon-Steelhead Sport Fishery." Journal of Wildlife Management 29, 266-279 (1965). Available in public and technical libraries.

Brown, W. G., A. K. Singh, and J. A. Richards. "Influence of Improved Estimating Techniques on Predicted Net Economic Values for Salmon and Steelhead." Agriculture Experiment Station, Oregon State University, Corvallis, Oregon, 1972.

Cesario, F. J. and J. L. Knetsch. "Time Bias in Recreation Benefit Estimates." Water Resources Research 6(3), 700-704 (1970). Available in public and technical libraries.

Charbonneau, J. J. and M. J. Hay. "Determinants of the Economic Values of Hunting and Fishing." Transactions of the 43rd North American Wildlife and Resources Conference, 1978.

Charles River Associates, Inc. "Benefits of Improving Visibility at Mesa Verde National Park." Boston, Massachusetts: Charles River Associates, Inc., November 1981.

Cicchetti, C. J., V. K. Smith, J. L. Knetsch, and R. A. Patton. "Recreation Benefit Estimation and Forecasting: Implications of the Identification Problems." Water Resources Research 8(4), 840-850 (1979). Available in public and technical libraries.

Cicchetti, C. J. and A. M. Freeman III. "Option Demand and Consumer's Surplus: Further Comment." Quarterly Journal of Economics 85(3), 528-539 (1971). Available in public and technical libraries.

Cicchetti, C. J., A. M. Freeman III, R. H. Haveman, and J. Knetsch. "On the Economics of Mass Demonstration: A Case Study of the November 1969 March on Washington." American Economic Review 61(4), 719-724 (1971). Available in public and technical libraries.

Clean Air Act (42 USC 7401 et seq.) as amended by the Clean Air Act Amendments of 1970 (Public Law 91-604), December 31, 1970, and the Clean Air Act Amendments of 1977 (Public Law 95-95), August 7, 1977.

Crocker, T. D. "The Use of Household Production Functions to Measure Intangible Environmental Impacts." Palo Alto, California: Electric Power Research Institute, 1977. 
Crocker, T. D. et al. Methods Development for Assessing Air Pollution Control Benefits Volume 1 , Experiments in the Economics of Air Pollution Epidemiology. EPA-6D0/5-79-001a. Prepared for the U.S. Environmental Protection Agency, Washington, D.C., 1979.

Cropper, M. et al. Methods Development for Assessing Air Pollution Control Benefits Volume $I \sqrt{\text {, Studies on Partial Equilibrium Approaches to Valuation }}$ of Environmental Amenities. EPA-600/5-79-001/d. Prepared for the U.S. Environmental Protection Agency, Washington, D.C., 1979.

Cummings, R. G. and W. C. Schulze. "Optimal Investment Strategies for Boomt owns: A Theoretical Analysis." American Economic Review 68(3), 374385 (1978). Available in public and technical Tibraries.

Currie, J. M., J. A. Murphy, and A. Schmitz. "The Concept of Economic Surplus." Economic Journal 81(324), 741-799 (1971). Available in public and technicat libraries.

Currie, J. W. and J. Kidd. A Documentation of Bidding Games Used in Measuring Social Value. PNL-2798. Richland, Washington, Pacific Northwest Laboratory, 1980. Available from Pacific Northwest Laboratory, Richland, Washington 99352.

Darling, A. "Measuring Benefits Generated by Urban Water Parks." Land Economics 49(1), 22-34 (1973). Available in public and technical Tibraries.

David, E. L. "Lake Shore Values: A Guide to Public Investment in Recreation." Water Resources Research 4(4), 697-707 (1968). Available in public and technical libraries.

Davis, R. "Recreation Planning as an Economic Problem." Natural Resources Journal 3, 239-249 (1963). Available in public and technical libraries.

Deyak, T. A. and V. K. Smith. "Residential Property Values and Air Pollution: Some New Evidence." Quarterly Review of Economics and Business 14(4), 93-100 (1974). Available in public and technical Tibraries.

EC0, Northwestern, Ltd. Review of Methods for Assessing the Enviranmental Costs and Benefits of Acquisitions. Prepared for the Bonneville Power Administration, Portland, Oregon, 1981.

Ejsel, L. M., G. D. Seinwill, and R. M. Wheeler Jr. "Improved Principles, Standards, and Procedures for Evaluating Federal Water Projects." Water Resources Research 18(2), 203-210 (1982). Available in public and technical Tibraries.

Electric Power Research Institute. Proceedings of a Workshop on the Measure of Intangible Environmental Impacts. Palo Alto, California: ETectric Power Research Institute, 1977. 
Feenberg, D. and E. S. Mills. Measuring the Benefits of Water Pollution Abatement. New York: Academic Press, 1980.

Fink, F., F. H. Buttner, and W. L. Boyd. Technical-Economic Evaluation of Air Pollution Corrosion Costs on Metals in the U.S. CoTumbus, Ohio: Battelle Memorial Institute, 1971.

Fisher, W. "Travel Cost and Contingent Value Estimates Explored." Prepared for presentation at the Eastern Economic Association Meetings, May 1, 1982.

Foster, H. and B. Bettie. "Urban Residential Demand for Water in the United States." Land Economics 55(1), 43-58 (1979). Available in public and technical Tibraries.

Freeman, A. M. III. "Approaches to Measuring Public Goods Demands." American Journal of Agricultural Economics 61(5), 915-925 (1979). Available in public and technical libraries.

Freeman, A. M. III. "A Survey of the Technique for Measuring the Benefits of Water Quality Improvement." In Cost-Benefit Analysis and Water Pollution Policy, Henry Peskin and Eugene Seskin, eds., Washington, D.C.: the Urban Institute, 1975, pp. 67-104.

Freeman, A. M. III. "On Estimating Air Pollution Control Benefits from Land Value Studies." Journal of Environmental Economics and Management 1(1), 74 83 (1974). Available in public and technical libraries.

Friedman, J. M., E. Niemi, and W. E. Whitelaw. Review of the Methodologies for Assessing the Environmental Costs and Benefits of Acquisitions. Prepared for the Bonneville Power Administration, Portland, Oregon, September 1981.

Fromm, G. "Comment." In Problems in Public Expenditure Analysis, S. B. Chase, ed., Washington, D.C.: the Brookings Institution, 1968, pp. 19661976.

Gordon, I. M. and J. L. Knetsch. "Consumer's Surplus Measures and the Evaluation of Resources." Land Economics 55(1), 1-10 (1979). Available in public and technical libraries.

Gramlich, F. W. "The Demand for Clean water: The Case of the Charles River." National Tax Journal 30(2), 183-194 (1977). Available in public and technical libraries.

Hammack, J. and G. M. Brown. Waterfowl and Wetlands: Toward Bioeconomic Analysis. Baltimore, Maryland: Johns Hopkins University Press, 1974. 
Haveman, R. and B. Weisbrod. "The Concept of Benefits in Cost-Benefit Analysis: With Emphasis on Water Pollution Control Activities." In CostBenefit Analysis and Water Pollution Policy, Henry Peskin and Eugene Seskin, eds. Washington, D.C.: The Urban Institute, 1978, pp. 37-65.

Haynie, F. H. "Economic Assessment of Pollution Related Corrosion Damage." Paper presented at the Electrochemical Society Symposium on Atmospheric Corrosion, October 6, 1980.

Hicks, J. A Revision of Demand Theory. Oxford, England: Clarendon Press, 1956.

Hori, H. "Revealed Preference for Public Goods." American Economic Review $65(5), 978-991$ (1975). Available in public and technical libraries.

Horst, R. L. and T. 0. Crocker. "The Value of An Aesthetic Phenomenon: Atmospheric Visibility in the 'Four Corners' Area of the United States." Paper presented at the Western Economic Association's Annual Conference, June 22, 1978.

Just, R. E. and D. L. Hurth. "Welfare Measures in a Multi-Market Framework." American Economic Review 69(5), 947-954 (1979). Available in public and technical libraries.

Keeney, R. L. and G. A. Robilliard. "Assessing and Evaluating Environmental Impacts at Proposed Nuclear Power Plant Sites." Journal of Environmental Economics and Management 4, 153-166 (1977). Avaitable in public and technical Tibraries.

Knetsch, J. L. and R. K. Davis. "Comparison of Methods for Recreation Evaluation." In Water Research, A. V. Kneese and S. C. Smith, eds., Baltimore, Maryland: Johns Hopkins University Press, 1966.

Krutilla, J. V. "Conservation Reconsidered." American Economic Review 57(4), 777-786 (1967). Available in public and technical libraries.

Kurz, M. "An Experimental Approach to the Determination of the Demand for Public Goods." Journal of Public Economics 3(4), 329-352 (1974). Available in public and technical tibraries.

Loehman, E., S. Ben-David, and V. H. De. "Measuring Oemand and Political Acceptability for Non-Market Goods: A Case Study of Health Effects Related to Air Quality." CEPR-IB-78-3. Stanford, California: Stanford Research International, 1978.

Long, M. F. "Collective-Consumption Services of Individual-Consumption Goods: Comment." Quarterly Journal of Economics 81(2), 351-352 (1967). Available in public and technical libraries. 
Maler, K. G. Environmental Economics: A Theoretical Inquiry. Baltimore, Maryland: Jotns Hopkins University Press, 1974.

Maler, K. G. and R. E. Wyzga. Economic Measurement of Environmental Damage. Paris, France: Organization for Economic Cooperation and Development, 1976.

Manual, E. H. et al. "Benefit Analysis of Alternative Secondary National Ambient Air Quality Standards for Sulfur Dioxide and Total Suspended Particulates (Draft Final Analysis)." Princeton, New Jersey: Mathtech, Inc., 1981.

Mathews, S. B. and G. M. Brown. Economic Evaluation of the 1967 Sport Fisheries of Washington. Technical Report 2. Olympia, Wastington:

Washington Department of Fisheries, 1970.

McMillan, M. "Estimates of Households' Preferences for Environmental Quality and Other Housing Characteristics from a System of Demand Equations." Scandinavian Journal of Economics 81(2), 174-187 (1979). Available in public and technical libraries.

Mehr, A. F, and R. G. Cummings. "Time Series Profile of Urban Infrastructure Stocks in Selected Boomtowns in Rocky Mountain States." Report LA-6687-MS. Albuquerque, New Mexico: Los Alamos Scientific Laboratory, April 1977.

Menz, F. C. and J. K. Mullen. "Expected Encounters and Willingness to Pay for Outdoor Recreation." Land Economics 57(1), 33-40 (1981). Available in public and technical libraries.

Meyer, P. A. Perceptions on Recreation and Sport Fisheries of the Chilliwack/Veddar River. Vancouver, British Columbia: Environment Canada and Department of Recreation and Conservation, 1976.

Meyer, P. A. Recreational/Aesthetic Values Associated with Selected Grouping of Fish and Widilife in Californta's Central Valley. Prepared for the U.S. Fish and Wildlife Service, Sacramento, California, 1980.

Meyer, P. A. The Value of Fish and Wildlife of San Francisco Bay: A Preliminary Survey. Prepared for the U.S. Fish and Wildlife Service, Sacramento, California, August 1979.

Meyer, P. A. A Comparison of Direct Questioning Methods for Obtaining Dollar Values for Public Recreation and Preservation. Technical Report Series 110. PAC 17-75-6. Vancouver, British Columbia: Environment Canada, 1974.

Mikesell, R. F. and R. M. Davis. "The Social Rate of Discount to be Applied to Public Projects: Some Unsettled Questions." Nebraska Journal of Economics and Business 19(1), 5-14 (1980). Available in public and technical Tibraries. 
Miller, J. R. "A Simple Economic Model of Endangered Species Preservation in the United States." Journal of Environmental Economics and Management 5(3), 292-300 (1978). Avaitable in public and technical libraries.

Mishan, E. J. Cost-Benefit Analysis. New York: Praeger Publishers, 1971.

Mishan, E. J. Introduction to Normative Economics. New York: Oxford University Press, 1981.

Muellbauer, J. "Household Production Theory, 'Quality and the Hedonic' Technique." American Economic Review 64(6), 977-94 (1974). Available in public and technical libraries.

Mulligan, P. J. "Willingness to Pay for Oecreased Risk for Nuclear Plant Accidents." Horking paper 43 (March). Pennsylvania State University, The Center for the Study of Environmental Policy, University Park, Pennsylvania, 1978.

Munley, V. G. and V. K. Smith. "Learning-by-Doing and Experience: The Case of Whitewater Recreation." Land Economics 52, 545-53 (1976). Available in public and technical libraries.

Munley, V. G. "A Note on Learning-by-0oing-to-Travel." Annals of Regional Science 11,61-70 (1977). Available in public and technical Tfbraries.

Muth, R. "Household Production and Consumer Demand Functions." Econometrica 34, 699-708 (1966). Available in public and technical libraries.

Nelson, J. P. Economic Analysis of Transportation Noise Abatement. Cambridge, Massachusetts: Ballinger, 1978.

Nero and Associates, Inc. "Study Module VI. Quantification of Environmental Costs and Benefits. Task 2. Preliminary Review of Research." Contract No. 82-020. submitted to Pacific Northwest Electric Power and Conservation Planning Council, Portland, Oregon, 1982.

Nero and Associates, Inc. "Study Module VI Quantificaiton of Environmental Costs and Benefits, Summary of Tasks 1-3." Portland, Oregon: Pacific Northwest Electric Power and Conservation Planning Council, June 1982.

Nero and Associates, Inc. "Study Module VI Quantification of Environmental Costs and Benefits, Task 1: Taxonomy of Impacts." Portland, Oregon: Pacific Northwest Electric Power and Conservation Planning Council, June 1982.

Norgaard, R. B. and D. C. Hall. "Environmental Amenity Rights, Transactions Costs, and Technological Change." Journal of Environmental Economics and Management 1, 251-267 (1974). Available in public and technical libraries. 
O'Hanlon, P. W. and J. A. Sinden. "Scope for Valuation of Envi ronmental Goods: Comment" Land Economics 54, 381-387 (1978). Available in public and technical libraries.

Oster, S. "Survey Results on the Benefit of Water Pollution Abatement in the Merrimack River Basin." Water Resources Research 13, 882-884 (1977). Available in public and technical Tibraries.

Pendse, D, and J. B. Wyckoff. "Scope for Valuation of Environmental Goods." Land Economics 50,89-92 (1974). Available in public and technical

Tibraries.

Peskin, H. and E. Seskin. "Introduction and Overview." In Cost Benefit Analysis and Water Pollution Policy, Henry Peskin and Eugene Seskin, eds., Washington, D.C.: The Urban Institute, 1975.

Polinsky, A. M., and D. L. Rubinfeld. "Property Values and the Benefits of Environmental Improvements: Theory and Measurement." In Public Economics and the Quality of Life, Lowdon Wingo and Al an Evan, eds., Baltimore, Maryland: Johns Hopkins University Press, 1977.

Rahamatian, M. Bidding Games and the Property Rights Problem. M. S. Paper. Department of Economics, University of Wyoming, May, 1979.

Randall, A. and D. S. Brookshire. "Pub1ic Policy, Public Goods and Contingent Valuation Mechanisms." Staff Paper 68. University of Kentucky, Lexington, Kentucky, 1978.

Randa11, A. et a1. "Reclaiming Coal Surface Mines in Central Appalachia: A Case Study of the Benefits and Costs." Land Economics 54, 472-489 (1978). Available in public and technical libraries.

Reiling, S. D., K. C. Gibbs, and H. H. Stoevener. Economic Benefits from an Improvement in Water Quality. Washington, D.C.: U.S. Environmental Protection Agency, 1973.

Rosen, S. "Wage-Based Indices of Urban Quality of Life." In Current Issues in Urban Economics, P. Mieszkowski and M. Straszheim, eds., Johns Hopkins University Press, Baltimore, Maryland, 1979.

Rowe, R., R. d'Arge, and D. Brookshire. Environmental Preferences and Effluent Charges. Research paper 6. Resource and Environmental Economics Laboratory, University of Wyoming, Laramie, Wyoming, May 1979.

Schmalensee, R. "Another Look at the Social Valuation of Input Price Changes." American Economic Review 66(1), 239-243 (1976). Available in public and technical libraries. 
Schulze, W., D. Brookshire, E. Walther and K. Kelley. The Benefits of Preserving Visibility in the National Parkiands of the Southwest. Prepared for the U.S. Environmental Protection Agency, Washington, D.C., 1980.

Sinclair, W. F. The Economic and Social Impact of the Kemana Il Hydroelectric Project on British Columbia's Fisheries Resources. Vancouver, British Columbia: Fisheries and Marine Service, Department of the Environment, 1976.

Sinden, J. A. "A Utility Approach to the Valuating of Recreational and Aesthetic Experiences." American Journal of Agricultural Economics 56(1), 61-72 (1974). Available in public and technical Tibraries.

Skjei, S. S. "Identification in the Estimation of Recreational Demand Curves from Cross-Section Data: How Important Is It?" Journal of Leisure Research 9(4), 301-309 (1977). Available in public and technical tibraries.

Smith, B. A. "Measuring the Value of Urban Amenities." Journal of Urban Economics 5(3), 370-387 (1978). Available in public and technical Tibraries.

Smith, V. K. The Economic Consequences of Air Pollution. Cambridge, Massachusetts: Ballinger Publishing Co., 1976.

Smith, V. K. "Travel Cost Demand Models for Wilderness Recreation: A Problem of Non-Tested Hypotheses." Land Economics 51(2), 103-111 (1975). Available in public and technical libraries.

Strauss, R. P. and G. D. Hughes. "A New Approach to the Demand for a Public Good." Journal of Public Economics 6(3), 191-204 (1976). Available in public and technical libraries.

U.S. Environmental Protection Agency. "Critical Review of Estimating Benefits of Air and Water Pollution Control." PB 285555. Washington, D.C.: U.S. Environmental Protection Agency, Office of Health and Ecological Effects, June 1978.

U.S. Fish and Wildlife Service, Division of Ecological Services. Human Use and Economic Evaluation. 104 ESM. Washington, D.C.: U.S. Fish and Wildlife Service, March 30, 1980.

U.S. Water Resources Council. "Water and Related-Land Resources Planning Principles, Standards and Procedures, Repeal of Regulations; Extension of Comment Period." Federal Register, Volume 47, Number 55, March 22, 1982.

U.S. Water Resources Council. "Environmental Quality Evaluation Procedures for Level C Water Resources Planning; Final Rule." Federal Register, Volume 45, Number 190, September 29, 1980. 
U.S. Water Resources Council. "Procedures for Evaluation of National Economic Development (NED) Benefits and Costs and Other Social Effects (OSE) in Water Resources Planning (Level C); Final Rule." Federal Register, Volume 45, Number 190, September 29, 1980.

Varian, H. Microeconomic Analysis. New York: W. W. Norton and Co., 1978.

Vaughn, W. J. and C. S. Russe11. "An Analysis of Participation in Nonconsumptive Wildlife Recreation: Comment." Land Economics 57(2), 279-287 (1981). Available in public and technical libraries.

Weisbrod, B. A. "Collective-Consumption Services of IndividualizedConsumption Goods." Quarterly Journal of Economics 78(3), 471-477 (1964). Available in public and technical libraries.

Wieand, K. F. "Air Pollution and Property Values: A Study of the St. Louis Area." Journal of Regional Science 13(1), 91-95 (1973). Available in public and technical libraries.

Willig, R. "Incremental Consumer's Surplus and Hedonic Price and Adjustment." Journal of Economic Theory 17(2), 227-253 (1978). Available in public and technical ibraries. 



\section{APPENDIX A \\ SENATE AND HOUSE VERSIONS OF THE REGULATORY REFORM BILL}

The purpose of the House version (H.R. 746)* and the Senate version (S. 1080) of the Regulatory Reform Bill is to "amend the Administrative Procedure Act to make regulations more cost-effective, to ensure review of rules, to improve regulatory planning and management, to enhance public participation in the regulatory process, and for other purposes."

The main difference between the two bills is whether or not independent regulatory agencies, including the NRC, will be under OMB's power to monitor and review implementation of the evaluation procedures required by law in this reform bill.** The House version explicitly excludes the independent agencies from OMB's oversight - although the independent agencies are still required to conform to the procedures. Conversely, the Senate version includes the independent agencies in the review process which is to be carried out by a Presidentially appointed officer, implicitly assumed to be the Director of $\mathrm{OMB} . \star \star \star$

The procedure process requires all agencies to publish a list of proposed regulatory actions which they might undertake, identifying those actions which are categorized as a "Major Rule," including a rule that "will have a substantial impact on health, safety, or the environment." The agency must issue an analysis of the projected benefits and adverse economic (and other) effects of the proposed rule and each of the principal alternatives, explaining how the benefits of the rule relate to the costs and other adverse effects of the rule.

ॠThe House Subcomittee on Administrative Law and Government Relations is responsible for reviewing H.R. 746. As of November 5, 1982, the House has still not scheduled any meetings or hearings on the Bill.

**Under Executive Order 12291 OMB has a responsibility to ensure that agencies conduct high quality analyses. The only means available to OMB for obtaining "better" regulatory analyses is to return the rules (and the RIAS) to the agencies for reconsideration.

$\star \star \star U . S$. General Accounting Office, "Improved Quality, Adequate Resources, and Consistent Oversight Needed If Regulatory Analysis Is To Help Control Costs of Regulations," Washington, D.C., GA0/PAD-83-6, November 2, 1982, p. 55. GAO recommends that $O M B$ play a broader role in overseeing the regulatory analysis process. "OMB should also broaden its effort in promoting the adoption of innovative techniques as an approach to reducing costs, rather than simply establishing less restrictive standards. OMB should play a more active role in reducing conflicts and overlaps and promoting greater consistency in regulatory policies. It should also promote the development of consistent methodologies for measuring regulatory impacts." (p. 5) 
According to the Senate version of the Bill, which has already been passed, an agency must issue a preliminary regulatory analysis when it publishes a notice of proposed rule making for a major rule. The preliminary analysis must contain:

(1) a description of the benefits, including any beneficial effects that cannot be quantified, and an explanation of how the agency anticipates each benefit will be achieved by the rule;

(2) a description of the costs of the rule, including any costs that cannot be quantified; and

(3) an explanation of how the benefits are likely to justify the costs.

The agency must describe the nature and extent of the nonquantifiable benefits and costs. The description of the benefits and costs of a proposed and final rule is to include a quantification, or numerical estimate, of the quantifiable benefits and costs. Such quantification, or numerical estimate, is to be made in the most appropriate unit of measurement and should specify the ranges of prediction and explain the margin of error involved in the methodology.

Although S. 1080 is ambiguous about whether Presidential oversight is procedural or substantive, the oversight is likely to have some substantive content and to reduce the independence of agencies like the NRC:

S. 1080 gives the President authority to 'monitor, review, and ensure agency implementation' of the regulatory analysis provisions of the bill for both executive branch and independent regulatory agencies... As passed by the Senate, S. 1080 does not distinguish between the degree of Presidential authority that can be exercised over executive departments and agencies and that can be exercised over independent regulatory agencies...the President is authorized to make binding recommendations to independent and executive branch regulatory agencies alike.*

ॠIbid., pp. 68-69. 


\section{APPENDIX B}

SOURCES OF SURVEY DATA

\section{INTRODUCTION}

There are several good sources of survey data which have been collected and are available for use in preparing economic valuation studies for nonmarket goods and impacts. The most comprehensive detailed data source is the 1980 National Survey of Fishing, Hunting, and Wildlife-Associated Recreation, designed specifically to provide location specific data of respondents' willingness-to-pay for deer, and waterfowl hunting and trout fishing activities, as well as expenditure and travel data for a variety of other hunting, fishing, and nonconsumptive recreational activities.

\section{USFWS 1980 NATIONAL SURVEY}

The U.S. Fish and Wildiife Service (USFWS) has recently compiled the results of its 1980 National Survey of Fishing, Hunting, and Wildlife Associated Recreation, * and is now conducting various analytical studies utilizing the data obtained. The 1980 Survey consists of three distinct questionnaires:

(1) A screening questionnaire conducted via telephone interview with 116,025 households nationwide, designed to gather socio-demographic data for each participating household and to identify potential participants (i.e., fishermen, hunters, and/or nonconsumptive wildlife users) for the two detailed user questionnaires.

(2) In-person interviews conducted with 30,163 persons identified as hunters or fishermen during 1980, which obtained information on participation rates, user days, expenditures and satisfaction levels for specific hunting and fishing activities, by nation, region and state. In addition, respondents were asked questions designed to estimate the economic value they placed on these resources.

(3) In-person interviews involving 6,253 persons identified as nonconsumptive wild ife users, which provided information on participation, expenditures and values for specific nonconsumptive wildlife associated activities, such as observing, feeding, and photographing wildiffe, on a national and regional basis.

The information generated by the two detailed survey questionnaires was specifically designed to provide necessary data with which to conduct 35 analytical research objectives outlined by the Division of Program Plans, $\star \star$

ÆThe 1980 Survey, conducted by the U.S. Bureau of the Census, is the sixth USFWS National Fishing and Hunting Survey, which has been conducted every five years since 1955 .

* The Division of Program Plans has published a data analysis design manual for the 1980 Survey data, A Plan for Data Analysis (1982). 
nine of which are directly concerned with estimating the monetary values assigned to recreational resources. The sample sizes for these two personal interview survey instruments were chosen so as to provide statistically significant results for the studies. For the Hunting and Fishing Users Questionnaire, the interview data were organized on a state basis -- the sample size of interviewed persons ranged from 254 in Rhode Island to 1,002 in Texas. Each state was further divided into fish and wildlife regions, and the respondents indicated the specific regions where they participated in recreational activities.

The second detailed personal interview survey, the Nonconsumptive Users Questionnaire, organized and reported the 6,253 nonconsumptive wildlifeassociated user repondents on a multi-state regional basis. The United States was divided into 9 regions for this survey; the number of interviewed cases ranged from 320 in the East South Central Region to 1,374 in the East North Central Region. Again, however, the respondents were asked to identify the specific fish and wildife regions within each state where they participated in nonconsumptive recreational activities.

Since the survey data for respondents' participation in fishing, hunting and nonconsumptive wildlife-associated recreation was gathered by geographic location, the number of individuals who participated in a given activity, in any specific region, can be determined by using the fish and wildlife state agency regional maps.

Types of consumptive activities which were reported in the questionnaire include, by species, recreational large and small-game hunting, waterfowl and migratory bird hunting, and noncommercial aspects of fishing. Various nonconsumptive wildlife activities include observing, photographing and feeding specific bird, animal, fish and other wildlife populations.

In the design stages of the 1980 USFWS National Survey, high priority was placed on the generation of economic values for fish and wildlife oriented recreational activities, using the gathered data from the detailed surveys. Several of the analytical studies which are being conducted presently, or are scheduled for future research, include:

(1) developing recreational, monetary values for fishing and hunting on a national, regional and state basis;

(2) evaluating the comparability of the following economic methodologies using the economic values generated with each technique:

- travel cost method

- hedonic-travel cost method

- willingness-to-pay bidding games;

(3) assessing the recreational values of nonconsumptive activities on a national and regional basis;

(4) evaluating the economic benefits of fish and wildife-asociated recreation to local, state, regional and/or national economies. 
The 1980 National Survey of Fishing, Hunting and Wildlife Associated Recreation provides the basis, then, for determining location-specific economic values for detailed fish and wildlife-related recreational activities. If acquired, the Survey data could be used to perform economic valuation studies for specific "nonmarket" recreational goods by area or size.*

\section{THE FEDERAL ESTATE SURVEY}

The Federal Estate Survey, a part of the 1977 Nationwide Outdoor Recreation Survey, ${ }^{\star *}$ consists of 11,000 personal interviews conducted on-site at 155 recreational areas under federal land management agencies. Hours of travel time and time spent at the site were collected, as well as the number of trips made annually to the particular site, the activities participated in, and the socio-economic characteristics of each respondent. This source of data could be utilized in performing travel cost studies aimed at deriving value estimates for recreational activities associated with specific sites.

\section{RECREATION RESOURCE MANAGEMENT SYSTEM}

The Army Corps of Engineers maintains the Recreation Resource Management System, which contains annual data on over 400 Corps recreation areas, including land and water resources at each site; use by month in visitor days; activities pursued by visitors; recreation expenditures; and location, population and road miles to the closest point of the nearest SMSA. This survey thus provides basic data on user participation for various activities at specific sites nationwide, as well as some useful information on travel distances and expenditures.

\section{OLD WEST NONRESIDENT TRAVEL AND RECREATION SURVEY}

Another potential source of data is the 1979 01d West Nonresident Travel and Recreation Survey, conducted by the 01d West Regional Commission. Detailed written questionnaires were completed by 3,500 nonresident visitors in the states of Montana, Nebraska, N. Dakota, S. Dakota and Wyoming, reporting their recreational activities and areas visited, expenditures, trip distances and other travel characteristics, and socio-economic information. This data might prove valuable in developing a variety of recreational value estimates implementing the travel cost methodology.

*The Survey data was made available for purchase from the Bureau of the Census as of March 1983.

**This survey was conducted by the Bureau of Outdoor Recreation and the Heritage Conservation and Recreation Service, now handled by the National Park Service, Department of the Interior. 


\section{RECREATION DEMANO SURVEY AND FORECASTS}

The Recreation Resources Center at the University of Wisconsin prepared the 1972 Upper Great Lakes Regional Recreation Planning Study, which included the Recreation Demand Survey and Forecasts. This survey provides data for 64,000 households on participation estimates for twelve outdoor recreation activities, origin-destination information, socio-economic and demographic characteristics for nine midwestern states. * Again, the travel cost technique might be applied using this data to develop dollar value estimates for recreational pursuits in the covered regions.

A broad spectrum of additional available data exists covering user estimates, recreational activities and, in some cases, socio-economic user information collected for numerous regions nationwide, many of which are on a sitespecific basis. A catalog of this and other available data which may be pertinent in conducting economic valuation studies has been prepared, entitled "A Survey of Available Data and Methods for Developing Environmental Asset Accounts" (Peskin et al., 1982).

Finally, the Nationwide Recreation Survey is not yet available, but it is a potential source of data for various recreational activities that may be used for conducting contingent market valuation studies.

\section{THE 1982-1983 NATIONWIDE RECREATION SURVEY}

The Nationwide Recreation Survey (NRS) is a personal interview survey which will be conducted in the fall of 1982 and the first half of 1983 by the University of Maryland's Survey Research Center, $\star \star$ for the National Park Service, the Forest Service, the Bureau of Land Management, and the Administration on Aging. This collection of recreational information represents the first interagency effort to conduct a recreation survey to provide a reliable and comparable data base for planning and policy development in the recreation field. The survey will consist of at least 4,500 personal interviews nationwide, representing the four Census Regions and the nine Census Divisions. The data will include:

(1) participation rates and volume of activity for selected outdoor recreation pursuits (i.e., canoeing, fishing, hunting, camping);

(2) recent and prospective changes in the allocation of time and money to outdoor recreation and related travel and purchases;

*The nine states sampled in the survey are: Illinois, Indiana, Iowa, Michigan, Minnesota, North Dakota, Ohio, and Wisconsin.

**The actual interviewing is being conducted by the U.S. Bureau of the Census under subcontract to the University of Maryland. 
(3) utilization and importance of outdoor recreation opportunities at varying distances from home;

(4) travel costs in terms of miles and time as they relate to selected activities and destinations; *

(5) socioeconomic characteristics of the respondents.

The survey instrument was specifically designed to provide the necessary data on recreation visits, expenditures, and travel distances and costs with which to perform travel costs analyses for selected activities. These studies, aimed at estimating the monetary values of recreational pursuits associated with specific sites, will be used by the Forest Service and the Bureau of Land Management in modeling recreation demand for the 1990 Resource Assessment and Program required by the Renewable Resources Planning Act of 1974. The actual valuation studies, based on the travel cost technique will be conducted by $\mathrm{Br}$. Harold K. Cordell of the Forest Service in Athens, Georgia.

The survey data will be available for outside analyses in late 1983, and may prove useful to the NRC in providing pertinent recreation participation and travel information from which to perform economic valuation analyses. The NRC might use this information in evaluating the benefits and costs of the nonmarket impacts (i.e., improved recreational fishing at a cooling lake) associated with a nuclear power facility.

*Activities for which travel data is being gathered include: canoeing, freshwater fishing, hunting, hiking, camping, and ski touring. 

APPENDIX C

ANALYSIS AND RECOMMENDATIONS REGARDING THE

TREATMENT OF "INDIRECT BENEFITS" IN THE DRAFT

ENVIRONMENTAL STATEMENT RELATED TD THE OPERATIDN

OF PERRY NUCLEAR PDHER PLANT, UNITS 1 AND 2

On May 5, 1982, Sunflower Alliance, et al., (Ref. 1) moved to amend its intervention before the Atomic Safety and Licensing Board and add two latefiled contentions. One of these contentions questioned the appropriateness of the inclusion of certain "Indirect" Benefits (i.e., local taxes, annual employment, and annual payroll) relating to plant operation in the recent Draft Environmental Statement (Ref. 2) published by the NRC staff. This appendix addresses this question.*

\section{CONCLUSIONS}

To remove any ambiguities that might be associated with the treatment of "Indirect Benefits" in Table 6.1, Reference 2, we recommend a reconfiguration of the information currently presented in the table. First, information pertinent to the nation's efficient use of resources should be presented -presumably in a table with a heading similar to that of Table 6.1. Second, any other information relevant to the local economy's efficient or equitable use of resources could be presented -- possibly in another table with a heading such as "Local Economic Impacts." This would be consistent with accepted procedures. For example, Mishan (Ref. 3) states: $\star \star$

So far we have omitted to identify the group which, in a costbenefit analysis, is taken as coterminous with society. If the economist is working for a corporation, or a local authority, it could be argued that his allegiance is primarily to the corporation, or to the local authority, and that he can therefore rightly ignore any gains and losses that fall on persons or businesses outside the jurisdiction of the corporation, or local authority. There is nothing to prevent the economist from confining his calculation in this way, though if he does so it behooves him to make his decision explicit. For the generally accepted view is that a cost-benefit analysis is undertaken on behalf of the nation at large....

*This appendix was formally submitted to the NRC as a short working paper in July, 1982. It is included in this report for documentation purposes.

**Al so, see Dasgupta, Sen and Margl in (Ref. 4), Sassone and Shaffer

(Ref. 5), and Water Resources Council (Ref. 6). 


\section{TAXES AND TRANSFER PAYMENTS}

From the perspective of social (i.e., national) benefit-cost analysis, taxes are merely transfer payments and therefore, should be excluded from efficiency considerations. As defined by Mishan (Ref. 7):*

A transfer payment, as the term suggests, is simply a transfer in money or kind made by one member or group in the community to others, one which is made not as payment for services received but either as a gift or as a result of legal compulsion. Transfer payments can be overt or concealed, and voluntary or compulsory, and they can appear as costs or as benefits to particular persons, firms, groups, or industries. But to the economy as a whole they are neither costs nor benefits; only a part of the pattern of distributing the aggregate product. In undertaking a cost-benefit analysis the economist must be careful to exclude them from the relevant magnitudes.

With respect to tax payments specifically, Mishan (Ref. 3, p. 69) states:

Although corporations will assess the profits of their enterprises net of all taxes, the economist interested in social cost-benefit analaysis -- which is tacitly understood by the term cost-benefit analysis, unless prefixed by the word private -- values all benefits gross of tax.

Therefore, taxes should be excluded from any analysis concerned with a national cost-benefit perspective.

However, the impact of any project (e.g., a nuclear power plant) on the fiscal condition of local communities is certainly a matter of importance. In fact, in response to a Presidential directive, the Water Resources Council (Ref. 6), in conjunction with other agencies (e.g., the Departments of Interior, Agriculture, Army) published a final rule to provide uniform requirements for implementation studies. These requirements detailed the development of four accounts for implementation studies: (1) the National Economic Development Account (NED), concerned with traditional cost-benefit analys is for national efficiency; (2) the Regional Economic Development Account (RED), concerned with changes in the regional distribution of economic activity; (3) the Environmental Quality Account (EQ), concerned with changes in the environment or ecosystems that cannot be monetized and included within the NED; and (4) Other Social Effects Account (OSE), concerned with that part of the NEPA human environment that registers plan effects from perspectives not included in the other three accounts. The categories listed include: urban and community impacts; life, health, and safety factors; displacement; long-term

*The definition of transfer payment contained in the Applicants Response is unnecessarily restrictive. 
productivity; and energy requirements and energy conservation. In fact, the impacts of a project on the fiscal condition of local communities are specifically mentioned.

It would, therefore, seem appropriate to include information on fiscal impacts (e.g., taxes) in a separate discussion from the analysis of national efficiency considerations.

\section{EMPLOYMENT AND PAYROLL}

With respect to employment and payroll, the traditional procedure is to consider labor costs as a payment to a factor of production and therefore to be included under project costs. Explicitly identifying increased employment as a goal of the project within the considerations of national efficiency has been criticized by economic analysts. There are, however, two possible approaches to removing the current ambiguities in Table 6.1.

First, the same approach suggested above for handing taxes could be implemented. Under the Regional Economic Development Accounts developed by the Water Resources Council (Ref. 6), changes in regional income (and its components, such as salaries and wages) and regional employment are specifically identified. Therefore these topics could be presented along with tax impacts in the supplemental discussion or tables dealing with matters normally considered outside the purview of standard social cost-benefit analysis.

Second, a more involved and difficult procedure could be followed. Normally, in social cost-benefit analysis, the analyst values the cost of factors of production (e.g., labor) at the prevailing market wage since the standard assumption is of a full-employment economy. (In a full-employment economy the opportunity cost of a factor such as labor is its market price, or wage rate.) If however, unemployed or underemployed resources such as labor exist, the actual social cost of employing such labor is less than the market wage rate. Therefore, in a situation of less than full employment, the labor costs assocjated with a project should be lowered when assessing the national efficiency of the proposed project.

However, there are three considerations which complicate the implementation of this procedure (Ref. 5). First, the analyst needs to know what portion of the project's labor costs are provided by otherwise unemployed or underemployed labor. Second, the analyst needs to know how long this otherwise unemployed or underemployed labor would have to remain in this state in the absence of the project. Finally, the analyst must assign a value, i.e., opportunity cost, to the labor employed. As the Water Resources Council states (Ref. 6, p. 64394):

(e) Use of otherwise unemployed or underemployed labor resources.

(1) If otherwise unemployed or underemployed labor resources are used in implementing a plan, the social cost of implementation is less than the financial cost. The opportunity cost of employing otherwise unemployed workers is conceptually equal to the value of leisure time foregone by such workers but may be 
assigned a zero value since there is no generally accepted procedure for measuring the value of leisure time. The opportunity cost of employing otherwise underemployed workers is equal to earnings under the without plan conditions.

(2) Conceptually, the effects of the use of unemployed or underemployed labor resources should be treated as an adjustment to the adverse effects of a plan on national economic development. Since this approach leads to difficulties in cost allocation and cost sharing calculations, the effects from the use of such labor resources are to be treated as an addi,tion to the benefits resulting from a plan.

(3) Beneficial effects from the use of unemployed or underemployed labor resources are limited to labor employed on site in the construction or installation of a plan. This limitation reflects identification and measurement problems and the requirement that national projections are to be based on a full employment economy.

Sassone and Shaffer (Ref. 5, p. 71) recommend that in the presence of unemployed resources, the analyst employ the expedient of assigning a value of zero to such otherwise unemployed labor for the first several years and then the market wage rate thereafter.

\section{RECOMMENDATIONS}

To remove any ambiguities that might be associated with Table 6.1's treatment of "Indirect Benefits," we recommend a reconfiguration of the information currently presented in Table 6.1. First, information pertinent to the nation's efficient use of resources should be presented -- presumably in a table with a heading similar to that of Table 6.1. Second, any other information relevant to the local economy's efficient or equitable use of resources could be presented, possibly in another table.

To clarify the discussion currently associated with Table 6.1 we recommend that the last sentence in Section 6.1 and all of Section 6.4 .1 be revised to reflect the proposed changes mentioned above. To clarify Table 6.1 we recommend that the current title be maintained to reflect the national efficiency considerations which would be the focus of the proposed alterations and that the proposed new table be titled, for example, "Local Economic Impacts."

\section{REFERENCES}

1. Sunflower Alliance et al., Motion for Leave to Submit Additional Contentions Before the Atomic Safety and Licensing Board, May 5, 1982.

2. U.S. Nuclear Regulatory Commission, Oraft Environmental Statement Related to the Operation of Perry Nuclear Power Plant, Units 1 and 2, NUREG-0884, Washington, 0.C., March 1982. 
3. E. J. Mishan, Cost-Benefit Analysis: An Introduction, P. 67, New York, Praeger Publishers, Inc. 1971.

4. P. Dasgupta, A. Sen, and S. Marglin, Guidelines for Project Evaluation, New York, United Nations, 1972.

5. P. G. Sassone and W. A. Shaffer, p. 71, Cost-Benefit Analysis: A Handbook, New York, Academic Press, 1978.

6. Water Resources Council, "Principles and Standards for Water and RelatedLand Resources Planning - Level C; Final Rule," Federal Register, 6436664400, September 29, 1980.

7. E. J. Mishan, Economics for Social Decisions: Elements of Cost-Benefit Analysis, p. 61, New York, Praeger Publishers, 1973. 

NUREG/CR-3194

PNL-4653

DISTRIBUTION

No. of

Copies

OFFSITE

U.S. Nuclear Regulatory

Commission

0ivision of Technical Informa-

tion and Document Control

7920 Norfolk Avenue

Bethesda, MD 20014

J. C. Prichard

Office of Nuclear Regulatory Research

U.S. Nuclear Regulatory Commission

Washington, D.C. 20555

\section{ONSITE}

50 Pacific Northwest Laboratory

J. W. Currie (8)

J. B. Burnham

L. D. Williams

R. M. Fleischmann

F. J. Cronin (19)

R. J. Nesse (5)

A. R. Wusterbarth (5)

M. Vaeth

$S$. Heaberlin

M. Hale

Publishing Coordination (2)

Technical Information (5) 



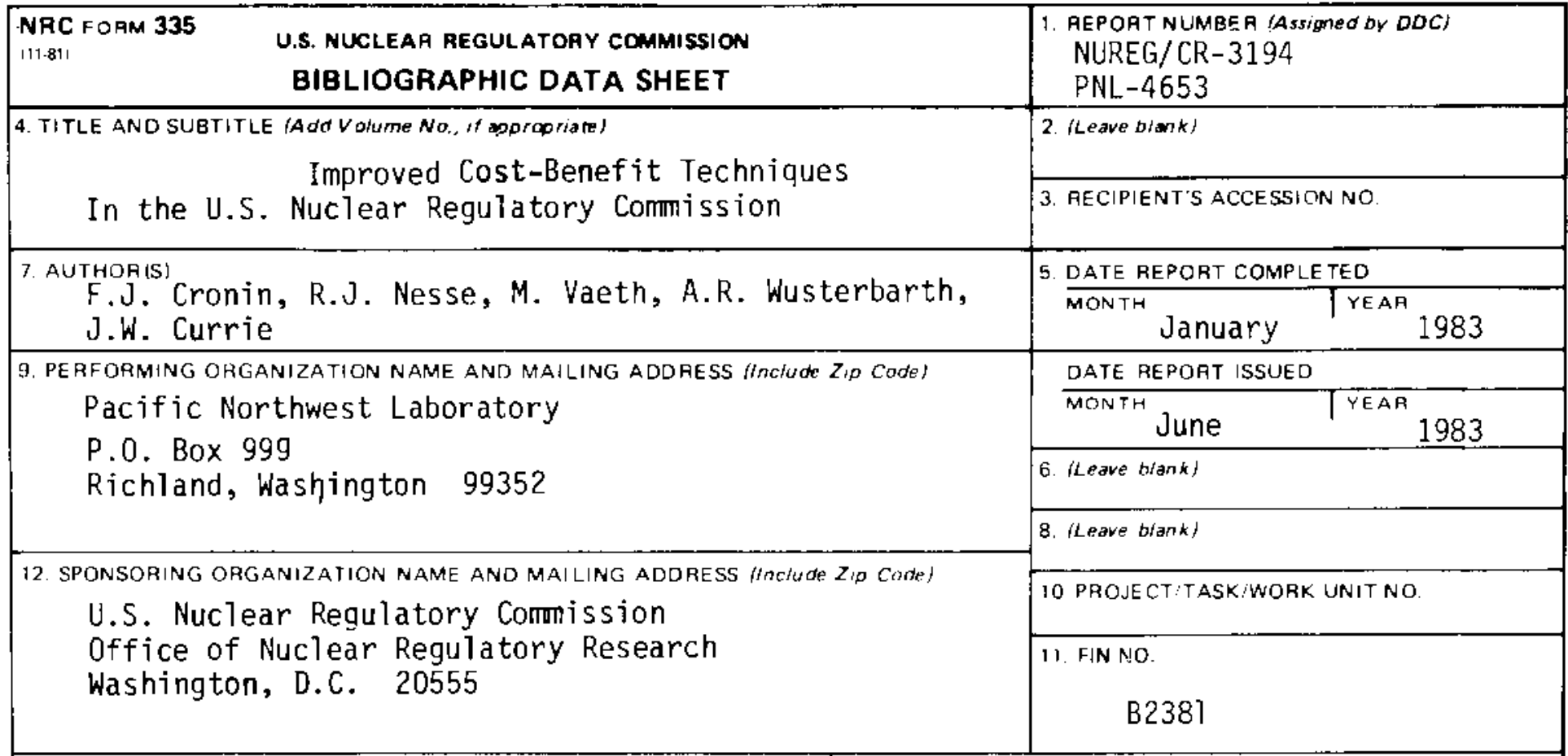

13 TYPE OF REPORT

PERIOO COVERED (tinciusive darest

15. SUPPLEMENTARY NOTES

14. (Le'ave olank)

16. ABSTAACT 200 wards or tesst

The major objective of this report is to help the U.S. Nuclear Regulatory Commission

(NRC) in its regulatory mission, particularly with respect to improving the use of cost-benefit analysis and the economic evaluation of resources within the NRC.

The objectives of this effort are: (1) to identify current and future NRC requirements (e.g., licensing) for valuing nonmarket goods; (2) to identify, highlight, and present the relevant efforts of selected federal agencies, some with over two decades of experience in valuing nonmarket goods, in this area; and (3) to review methods for valuing nonmarket impacts and to provide estimates of their magnitudes.

Recently proposed legislation may result in a requirement for not only more sophisticated valuation analyses, but more extensive applications of these techniques to issues of concern to the NRC. This paper is intended to provide the NRC with information to more efficiently meet such requirements.

11. KEY WORDS AND DOCUMENT ANALYSIS

17 DESCAIPTORS

Economic Analysis

Environmental Analysis

Cost-Benefit Analysis

Regulatory Analysis

17b. IDENTIFIE RS: OPEN-ENDED TERMS

18. AVAILABILITY STATEMENT

Unlimited

\begin{tabular}{|l|l|}
\hline 19 SECURITY CLASS ithis report & 21. NO. OF PAGES \\
Unclassified & \\
\hline 20 SECURITY CLASS / Tho payej & 22 PRICE \\
Unclassifjed
\end{tabular}


